UNIVERSIDADE DE SÃO PAULO

ESCOLA DE COMUNICAÇÕES E ARTES

DANIELA DOS SANTOS DOMINGUES MARINO

As gibitecas como polos fomentadores de cultura e de exercício

da cidadania

SÃO PAULO, 2018 


\title{
As gibitecas como polos fomentadores de cultura e de exercício da cidadania
}

\author{
Versão corrigida \\ (Versão original disponível na Biblioteca da ECA/USP)
}

Dissertação de Mestrado apresentada à Escola de Comunicações e Artes da Universidade de São Paulo para obtenção do título de Mestre em Ciências da Comunicação Área de concentração: Interfaces Sociais da Comunicação Linha de pesquisa: Comunicação, Cultura e Cidadania Orientador: Prof. Dr. Waldomiro de Castro Santos Vergueiro 


\section{FOLHA DE APROVAÇÃO}

MARINO, D.S.D., As gibitecas como polos fomentadores de cultura e de exercício da cidadania. Dissertação de Mestrado apresentada ao Programa de Pós-Graduação em Ciências da Comunicação da Escola de Comunicações e Artes da Universidade de São Paulo, na Área de Concentração: Interfaces Sociais Comunicação, na Linha de Pesquisa: Comunicação, Cultura e Cidadania, para a obtenção do título de Mestre em Ciências da Comunicação.

Aprovado em:

\section{Banca Examinadora}

Prof. Dr.:

Instituição:

Julgamento:

Assinatura:

Prof. Dr.:

Instituição:

Julgamento:

Assinatura:

Prof. Dr.:

Instituição:

Julgamento:

Assinatura:

Prof. Dr.:

Instituição:

Julgamento:

Assinatura: 
Autorizo a reprodução e divulgação total ou parcial deste trabalho, por qualquer meio convencional ou eletrônico, para fins de estudo e pesquisa, desde que citada a fonte.

Catalogação na Publicação

Serviço de Biblioteca e Documentação

Escola de Comunicaçōes e Artes da Universidade de São Paulo

Dados inseridos pelo(a) autor(a)

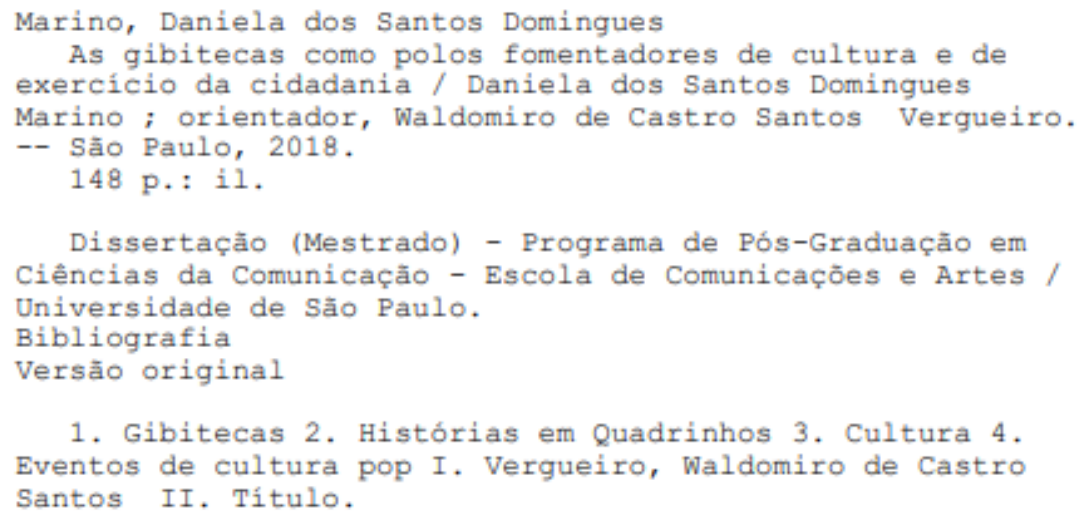

CDD 21.ed. - 302.2 


\section{AGRADECIMENTOS}

À Escola de Comunicações e Artes da Universidade de São Paulo e ao Programa de PósGraduação em Ciências da Comunicação - PPGCOM - pela oportunidade de desenvolver essa pesquisa dentro da área de Interfaces Sociais da Comunicação, principalmente pela possibilidade de conviver com docentes e discentes que acreditam fortemente no compartilhamento do conhecimento acadêmico como uma forma de promover bem-estar social.

Ao meu orientador, prof. Dr. Waldomiro de Castro Santos Vergueiro, cuja paciência e generosidade sempre andaram lado a lado com o rigor acadêmico e à atenção aos detalhes. Certamente, suas considerações e cuidado servirão como referências para minhas práticas acadêmicas.

À Danielle de Oliveira Costa Lhoret, orientadora na graduação que me levou a conhecer as pesquisas acadêmicas de quadrinhos e cuja amizade tem sido um dos maiores presentes que ganhei nos últimos anos.

Ao Gazy Andraus, pela amizade e apoio para que eu me dedicasse à pesquisa, me convidando a participar das reuniões do Observatório de histórias em quadrinhos da ECA e da Associação de Pesquisadores em Arte Sequencial, a ASPAS.

Aos queridos amigos da ASPAS, especialmente à Natania Nogueira e Valéria Bari, que estão entre as principais referências deste trabalho, e Iuri Reblin por todo incentivo ao longo do processo.

A todos os meus colegas de Observatório de histórias em quadrinhos, em especial à Edilaine Correa e à Beatriz Sequeira, que se tornaram não só grandes amigas, como importantes referências acadêmicas, assim como Luiz Salles, responsável pelo vídeo de aniversário de 25 anos da Gibiteca de Santos.

Aos amigos recentes e amigos antigos, acadêmicos ou não, que sempre acreditaram em mim, mesmo quando eu não acreditei. Especialmente à Laluña Machado por toda ajuda na fase final desse processo, à Clarissa Monteiro e à Andréa Lagareiro por todo incentivo.

À Coordenação de Aperfeiçoamento Pessoal de Nível Superior (CAPES) cujo apoio financeiro viabilizou a realização dessa pesquisa.

À minha mãe, Léa, meu maior ídolo, cujo exemplo sempre me fez acreditar que eu poderia chegar onde quisesse, e cujo amor e suporte possibilitaram que eu pudesse cursar uma pós-graduação mesmo diante de inúmeras adversidades.

Ao meu marido e melhor amigo, Ronaldo, que sempre me incentivou em tudo que eu quis fazer. Sem seu apoio, amor e compreensão, eu jamais conseguiria terminar esta jornada.

À minha filha, Sofia, que hoje pode não entender muito bem o que significa esse processo todo, mas que com sua doçura e paciência nunca me cobrou nas vezes que fui negligente para poder entregar um trabalho ou frequentar eventos e disciplinas.

À coordenação e aos funcionários da Gibiteca Municipal de Santos por todas as informações cedidas, especialmente Fábio Tatsubô e Narayana Fida Mamede.

Aos artistas e público que ao longo dos últimos anos participaram dos eventos realizados na Gibiteca e a todos os amigos que fiz lá. 
"É sobre o que você acredita e eu acredito no amor. Somente o amor pode realmente salvar o mundo."

Diana Prince 


\section{RESUMO}

MARINO, Daniela dos Santos Domingues. As gibitecas como polos fomentadores de cultura e de exercício da cidadania. 2018. 148f. Dissertação (Mestrado) - Escola de Comunicações e Artes, Universidade de São Paulo, São Paulo, 2018. O presente trabalho foi realizado com apoio da Coordenação de Aperfeiçoamento de Pessoal de Nível Superior - Brasil (CAPES) - Código de Financiamento 001

O presente trabalho visa buscar maior compreensão acerca do papel das gibitecas como espaços que servem a um propósito mais amplo que apenas armazenar revistas de histórias em quadrinhos. Como apontam Bari (2008), Nogueira (2017) e Vergueiro (1994), o aumento no número de espaços dedicados exclusivamente à leitura de histórias em quadrinhos no Brasil tem sido observado desde o início dos anos 1990, da mesma forma que observou Vergueiro (2017) em relação ao aumento no número de publicações em quadrinhos no país. Diversos fatores podem ter contribuído para o aquecimento do mercado nacional de quadrinhos, entre eles, o advento da internet, que possibilita que os autores possam divulgar seus trabalhos a uma quantidade cada vez maior de leitores; a indicação dos Parâmetros Curriculares Nacionais para que os quadrinhos sejam usados em sala de aula; a possibilidade de publicação de histórias em quadrinhos por meio de editais estaduais; e o processo de legitimação das histórias em quadrinhos como bens culturais de mesmo valor que outras expressões artísticas, como previsto em Carvalho (2017). A hipótese na qual se baseia a pesquisa é de que as gibitecas podem constituir polos de fomento à cultura e de exercício da cidadania ao promoverem eventos para divulgação dos quadrinhos e disponibilizam seus acervos gratuitamente aos cidadãos das comunidades onde estão inseridas. A partir da perspectiva de teóricos da Comunicação como Jesus Martin-Barbero (1997, 2000) e Nestór Canclini (1999) sobre a importância dos eventos sociais para a compreensão dos fenômenos de comunicação, principalmente no que tange à América Latina; e as considerações de teóricos da cultura como Raymond Williams (1961, 2008) e dos Estudos Culturais de Matellart e Neveu (2002) sobre os aspectos sociais do acesso à cultura, o objeto a ser analisado é composto pelos eventos ocorridos na Gibiteca Municipal de Santos entre os anos de 2013 e 2016, período em que o local presenciou o aumento de mais de $100 \%$ de atividades oferecidas aos seus frequentadores em comparação aos anos anteriores. Para a análise destes eventos são utilizados estudo de caso, etnografia, entrevistas e pesquisa bibliográfica que buscam relacionar as considerações dos autores elencados à observação participativa da autora ao longo dos anos mencionados. $\mathrm{O}$ acesso à cultura como uma forma de exercer a cidadania é defendido por Marshall (1967) e complementado por teóricos da Geografia Cultural (CUCHE, 2002; COSGROVE; 2007; CORRÊA, ROSENDAHL, 2007) quando se referem à relevância de certos espaços para a construção e aquisição de conhecimento para determinados grupos. Em relação a esses grupos, que no caso da Gibiteca são seus frequentadores, suas interações remetem ao que Pustz (2000) atesta sobre a existência de uma cultura específica de histórias em quadrinhos, cujos elementos constitutivos são específicos e compartilhados pelas pessoas que consomem seus produtos. Assim, por meio da exposição dos dados coletados e da bibliografia pertinente à pesquisa, foi possível concluir se a hipótese inicial se confirma, possibilitando então, que o debate acerca da relevância das gibitecas seja expandido.

Palavras-chave: gibitecas; histórias em quadrinhos; cultura; cidadania. 


\begin{abstract}
MARINO, Daniela dos Santos Domingues. The comics libraries as places of promotion of culture and exercise of citizenship. 2018. 148f. Dissertação (Mestrado) - Escola de Comunicações e Artes, Universidade de São Paulo, São Paulo, 2018. This study was financed in part by the Coordenação de Aperfeiçoamento de Pessoal de Nível Superior Brasil (CAPES) - Finance Code 001
\end{abstract}

This study aims to seek deeper comprehension about the role of the comics libraries (gibitecas) as places that serve to a greater purpose than only store comic books. As Bari (2008), Nogueira (2017) and Vergueiro (1994) indicate, the increase in the number of places dedicated exclusively to comic books reading in Brasil has been noticed since the 1990's, as well as the number of comic books releases, as observed by Vergueiro (2017). Many factors may have contributed to the warming of the national comics market, among them, the internet, that enables artists to broadcast their works to a larger number of comic readers; the indication of the National Curricular Parameters (Parâmetros Curriculares Nacionais) so that the comics are used in the classroom; the possibility of publishing comic books by public edicts; and the legitimizing comics process as cultural products with the same value as other artistic expressions, as in Carvalho (2017). The hypothesis on which the research is based is that the gibitecas can constitute means to promote culture and exercising the citizenship by promoting events to divulge comics and making their collections available to the citizens of the communities where they are inserted. From the perspective of Communication theorists such as Jesus Martin-Barbero $(1997,2000)$ and Nestór Canclini (1999) on the importance of social events for understanding communication phenomena, especially in Latin America; and the considerations of cultural theorists such as Raymond Williams (1961, 2008) and Matellart and Neveu (2002) Cultural Studies on the social aspects of access to culture, the object to be analyzed is composed of the events that took place in the Gibiteca Municipal de Santos between the years of 2013 and 2016, during which time the place witnessed an increase of more than $100 \%$ of activities offered to its visitors, compared to previous years. For the analysis of these events we use a case study, ethnography, interviews and bibliographical research that seek to relate the considerations of the authors listed to the participant observation of the author over the mentioned years. Access to culture as a way of exercising citizenship is defended by Marshall (1967) and complemented by cultural geography theorists (CUCHE, 2002; COSGROVE; 2007; CORRÊA, ROSENDAHL 2007) when they refer to the relevance of certain spaces for the construction and acquisition of knowledge for certain groups. In relation to these groups, which in the case of Gibiteca are their regulars, their interactions refer to what Pustz (2000) attests about the existence of a specific culture of comic books, which constitutive elements are specific and shared by the people who consume their products. Thus, through the exposition of the collected data and the bibliography pertinent to the research, it was possible to conclude if the initial hypothesis is confirmed, allowing then, that the debate about the relevance of the gibitecas is expanded.

Keywords: comics libraries; comic books; culture; citizenship. 


\section{LISTA DE FIGURAS}

Figura 1 - Nota sobre o fechamento da Gibiteca publicada no jornal A Tribuna

Figura 2 - Gibiteca Henfil

Figura 3 - Biblioteca São Paulo

Figura 4 - Carta em homenagem a Marcel Rodrigues Paes no jornal A Tribuna 71

Figura 5 - Matéria de Marcel Rodrigues sobre contenção de praga nas revistas em quadrinhos publicada no jornal A Tribuna

Figura 6 - Matéria de Marcel Rodrigues sobre bancas de jornais em Santos para a compra de quadrinhos publicada no jornal A Tribuna.

Figura 7 - Matéria sobre a inauguração da Gibiteca publicada no jornal A Tribuna.......73

Figura 8 - Convite de abertura da Gibiteca

Figura 9 - Imagem do interior da Gibiteca em 1993

Figura 10 - Foto do posto de salvamento na época de sua inauguração 75

Figura 11 - Foto da Gibiteca após a reforma do posto de salvamento .76

Figura 12 - Gráfico das atividades da Gibiteca entre os anos de 2013 e 2016

Figura 13 - Gráfico do número de participantes das atividades realizadas na Gibiteca entre 2013 e 2016 .82

Figura 14 - Matéria sobre a Gibiteca publicada no Diário Oficial .84

Figura 15 - Bate-Papo sobre mercado internacional de quadrinhos .86

Figura 16 - Fanzines lançados no dia nacional do Fanzine em 2015. .88

Figura 17 - Capa da história em quadrinhos institucional Receptação é Crime . .90

Figura 18 - Baú da Gibiteca .92

Figura 19 - Caixas de feira de trocas de quadrinhos .93

Figura 20 - Matéria sobre o acervo da Gibiteca publicada no jornal A Tribuna . .94

Figura 21 - Graphic novel Angola Janga doada à Gibiteca de Santos .95 
Figura 22 - Visita assistida à Gibiteca - pessoas com deficiência auditiva ......................96

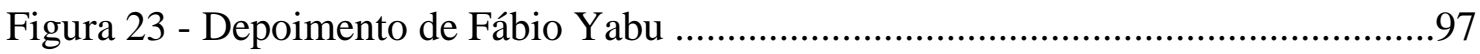

Figuras 24 e 25 - Exposição de Larissa Medeiros - Deficiente auditiva...........................99

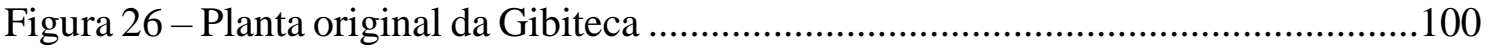

Figura 27 - Magafile - arquivos como os usados na Universidade de Michigan.............102

Figura 28 - Caixas onde são acomodados os quadrinhos na Gibiteca de Santos............102

Figuras 29 e 30 - Encadernados de Antonio Gobbo ....................................................103

Figura 31 - Revistas do arquivo da Gibiteca Henfil...................................................104

Figura 32 - Revista Gibi - Arquivo da Gibiteca Henfil .............................................104

Figura 33 - Livros acadêmicos sobre quadrinhos da Gibiteca de Santos.....................105

Figura 34 - Escola Tatibitati em visita à Gibiteca de Santos .......................................110 


\section{SUMÁRIO}

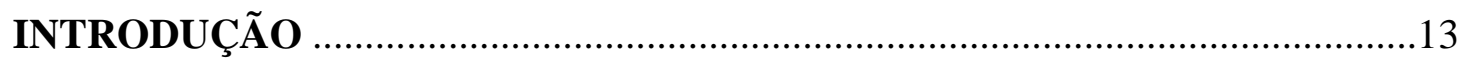

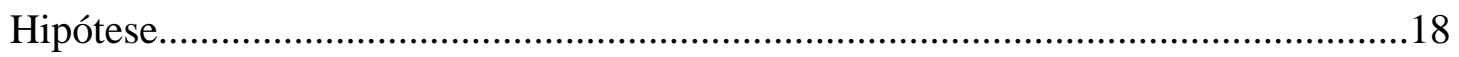

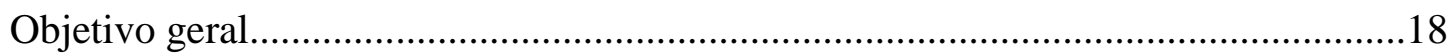

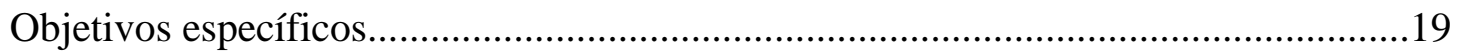

Metodologia e fundamentação teórica......................................................................19

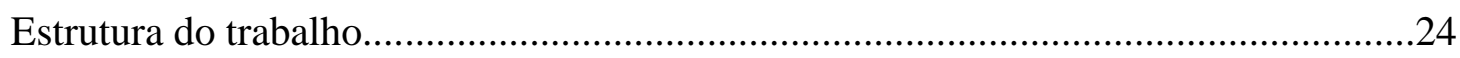

1 CULTURA, CIDADANIA E AS GIBITECAS .................................................2

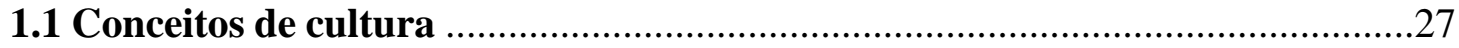

1.2 Acesso à cultura como um meio de exercer a cidadania ...................................32

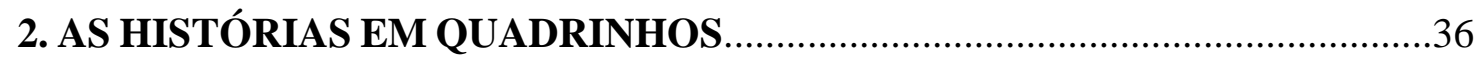

2.1 As histórias em quadrinhos ao longo da História................................................

2.2 As histórias em quadrinhos como bens culturais..........................................46

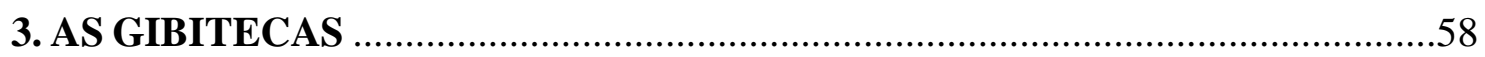

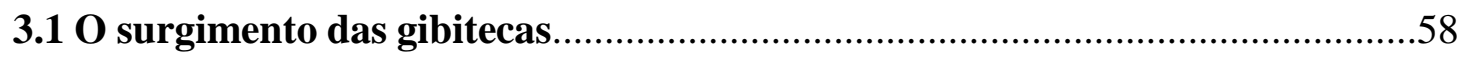

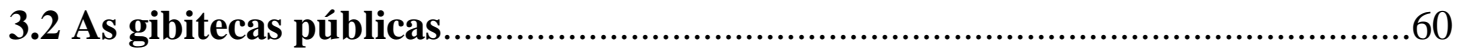

3.3 Manutenção, catalogação e programação de eventos das gibitecas...................66

4. A GIBITECA MUNICIPAL DE SANTOS - MARCEL RODRIGUES PAES....71

4.1. A História da gibiteca municipal de Santos.................................................. 71

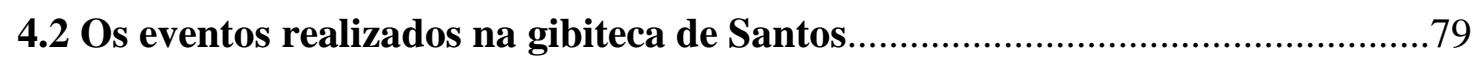

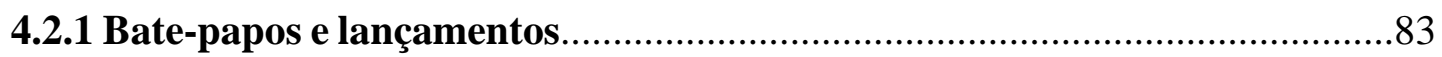

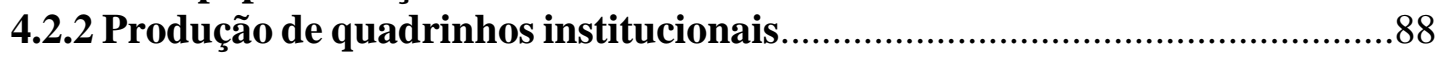

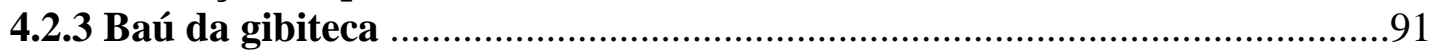

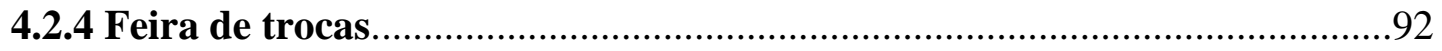

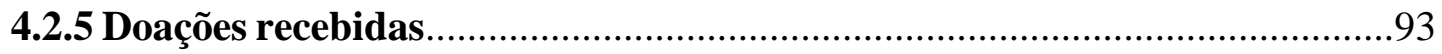

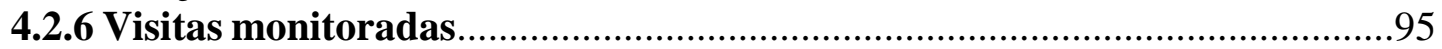

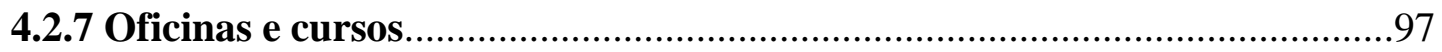

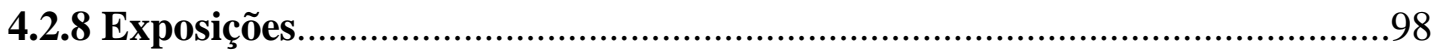

4.3 A Constituição física da gibiteca municipal de Santos e seus problemas..........100 


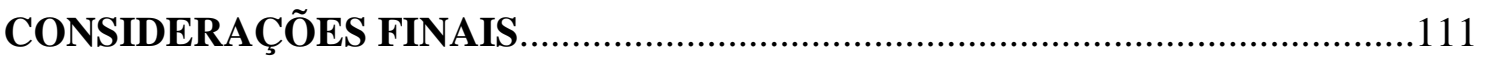

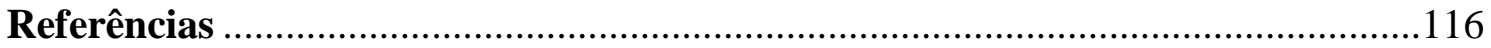

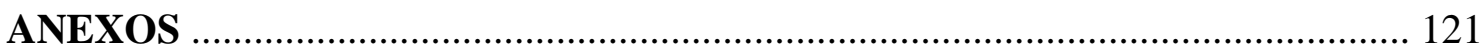

ANEXO 1 - Relatório de atividades da Gibiteca de Santos ...................................122

ANEXO 2- Tabelas dos eventos realizados por data...........................................124

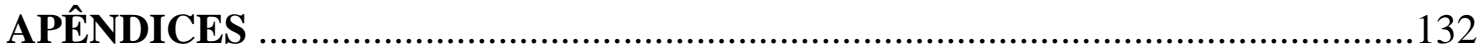

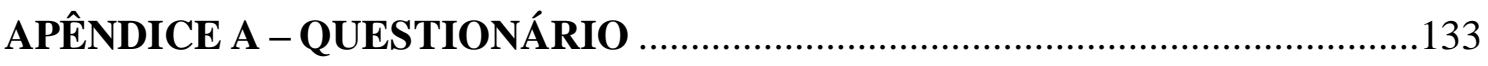

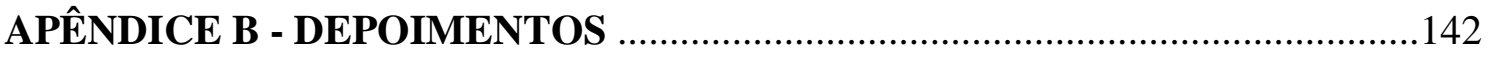

APÊNDICE C - DADOS DAS GIBITECAS MENCIONADAS NA PESQUISA...145 


\section{INTRODUÇÃO}

Tendo sido alfabetizada com as revistas em quadrinhos da Turma da Mônica, assim como muitos brasileiros, minha relação com os quadrinhos só era um pouco mais próxima devido à coleção que meu pai possuía. Ainda assim, o conhecimento sobre os estudos acadêmicos de arte sequencial veio tardiamente, quando cursava a faculdade de Letras.

Meu ingresso nesse universo está diretamente ligado ao tema de minha pesquisa, pois foi na Gibiteca de Santos que conheci o pesquisador Gazy Andraus, que posteriormente me convidaria a participar das reuniões mensais do Observatório de Histórias em Quadrinhos da Escola de Comunicações e Artes (ECA), sob a coordenação do meu atual orientador, o Prof. Dr. Waldomiro Vergueiro.

Participando dos encontros do Observatório desde outubro de 2013, venho então acumulando conhecimento referente à produção acadêmica relacionada aos estudos de histórias em quadrinhos. Nesse ínterim, além de confeccionar algumas das atas das reuniões, juntamente com outras duas colegas, também me associei à ASPAS - Associação de Pesquisadores em Arte Sequencial.

Meu primeiro contato com os eventos acadêmicos de histórias em quadrinhos ocorreu em 2013, quando participei das II Jornadas Internacionais de Histórias em Quadrinhos, promovidas pela ECA. Nesta mesma época, tive a oportunidade de conhecer o professor convidado do evento, John Lent, responsável pela edição do International Journal of Comic Art - IJOCA, onde publiquei dois artigos.

Paralelamente aos eventos acadêmicos, venho desde 2013 participando de eventos de quadrinhos, seja como convidada ou como público, principalmente nos que costumam acontecer semanalmente na Gibiteca de Santos.

Entre outubro e dezembro de 2016 eu colaborei com a organização e assessoria desses eventos a convite do responsável pela programação da Gibiteca de Santos, Fábio Tatsubô. Durante esses três meses, pude me aproximar ainda mais dos funcionários do local e entender como o espaço funciona e como funcionam a organização dos gibis e sua distribuição e troca por meio de projetos como a Feira de Trocas e o Baú da Gibiteca, que serão detalhados no quarto capítulo da dissertação. 
Escolher um tema para um projeto de pesquisa não é uma tarefa das mais fáceis. Frequentando eventos acadêmicos sobre histórias em quadrinhos há pelo menos quatro anos, foi possível acompanhar diversos trabalhos sobre os mais variados temas relacionados às aplicações da Nona Arte. No entanto, alguns deles me chamaram a atenção, especialmente pelo depoimento de colegas acerca das dificuldades na implementação e manutenção de gibitecas.

A desativação de gibitecas, sejam elas escolares ou não, parece ser algo recorrente quando há mudança de gestão ou conflito de interesses onde elas são mantidas. Alguns relatos atribuem à falta de espaço físico para alocar as revistas em quadrinhos um dos fatores de seu desmantelamento, como mencionado por Patrícia Pina durante a exposição de sua pesquisa no colóquio do Observatório de Histórias em Quadrinhos, realizado no dia 12 de fevereiro de 2016, na Escola de Comunicações e Artes da Universidade de São Paulo (USP). A educadora Thina Curtis, em uma visita à Gibiteca de Santos em outubro de 2016, explicou aos presentes que, em várias escolas onde trabalhou, observou o fechamento ou o descaso com as gibitecas. Seu depoimento é corroborado pelo responsável pela Gibiteca de Santos até dezembro de 2017, Fábio Tatsubô, que implementou uma gibiteca na cidade de São Vicente e que também não existe mais. Seja qual for o real motivo da não manutenção destes espaços, a forte associação da leitura dos quadrinhos a uma prática sem importância pode ser um dos fatores que levam gestores a não dispensarem a mesma atenção às gibitecas que dispensam a outros equipamentos turísticos e culturais.

Scott (1991) afirma que a aquisição de material para pesquisa e formação de acervo não é algo fácil de se fazer, uma vez que colecionar revistas em quadrinhos exige comprometimento e assiduidade, principalmente em relação aos títulos seriados.

Assim, se alguém decidir estudar um determinado arco de um personagem dependendo exclusivamente de uma biblioteca especializada ou uma gibiteca, essa pode se tornar uma tarefa inglória, uma vez que muitos desses espaços dependem de doações e estas nem sempre fornecem séries completas:

Eu gostaria de sugerir que a principal razão para não haver histórias, análises e livros de referência sobre quadrinhos é porque colecionar quadrinhos é uma tarefa muito árdua e as bibliotecas não têm colecionado adequadamente. Ainda que haja algumas coleções de quadrinhos significativas em bibliotecas universitárias, existem muito poucas bibliotecas que adquirem os melhores lançamentos, mesmo quando se trata de quadrinhos políticos e de não-ficção. Por exemplo, existem apenas algumas poucas bibliotecas universitárias com mais de quatro ou 
cinco coleções dessas. Uma biblioteca realmente funcional teria centenas de coleções. (SCOTT, 1991, p. 9, Tradução nossa1 ${ }^{\text {) }}$

Ainda na concepção de Scott (1991), embora a catalogação e estudo de histórias em quadrinhos não seja uma especialização acadêmica na área de Biblioteconomia, ele defende que o ideal seria que houvesse ao menos um especialista em cada estado ou, quem sabe, cidade, dadas as peculiaridades das publicações. No entanto, ao contatar responsáveis por algumas gibitecas, o que se observa é que não há funcionários especializados em lidar com revistas em quadrinhos. Em alguns casos, como nas gibitecas de Belo Horizonte e Curitiba, existe uma assessoria voluntária por parte de pessoas que trabalham diretamente com quadrinhos, como é o caso de Afonso Andrade, um dos organizadores do Festival de Quadrinhos de Belo Horizonte, o FIQ, e que colabora com a Gibiteca Municipal Antonio Gobbo ${ }^{2}$.

Ainda assim, um estudo feito com nove gibitecas (SEVERO, 2012, p. 94) constatou que sete delas contavam com profissionais de Biblioteconomia, enquanto as outras duas possuíam pessoas com licenciatura entre os coordenadores, indicando que existe uma tendência de que mais profissionais especializados sejam contratados para gerir esses locais.

Vergueiro (2003b) afirma que o ingresso dos quadrinhos nas bibliotecas públicas ou escolares "foi vetado pelo enorme estardalhaço que seus opositores geralmente costumavam fazer contra eles, manifestando-se, às vezes de maneira agressiva, quando surgisse a mais remota possibilidade de colocá-los à disposição do público". Por isso, a criação ou manutenção de espaços destinados à leitura dos quadrinhos não é uma regra para as instituições públicas, mas uma exceção (VERGUEIRO, 2003b). Mesmo quando esses espaços são viabilizados, o autor explica que há um tratamento discriminatório ou "diferenciado" em relação a outros materiais porque:

\footnotetext{
${ }^{1}$ I would like to suggest that a major reason that there are not enough histories, analyses and reference books about comics is that collecting comics is a very difficult job, and libraries have not been collecting well enough. Although there are some significant university collections of comics material, there are very few libraries that routinely acquire the best of what is newly published, even of political and nonfiction comics. For example, there are only a handful of university libraries with complete or nearly complete runs of any comic book or strip that has lasted for twenty years or more, and there are no university libraries with more than four or five such collections. A really useful library would have hundreds of such collections.

${ }^{2}$ Informações concedidas por Afonso Andrade, colaborador da gibiteca Antônio Gobbo, em visita realizada ao local em julho de 2016.
} 
- eles não são incorporados de forma definitiva ao acervo, sendo encarados como material totalmente descartável, não merecedor de qualquer iniciativa visando a sua preservação e conservação;

- enfrentam total despreocupação com o estabelecimento de critérios objetivos para sua seleção, todos os produtos quadrinhísticos sendo considerados essencialmente iguais entre si pelos bibliotecários;

- são objeto de excessivas restrições financeiras para sua aquisição em base regular, a eles não se destinando qualquer verba para compra de revistas ou álbuns de quadrinhos e sendo considerados como alternativa para o acervo apenas quando oferecidos em doação, sem ônus institucional direto (em geral, muitos bibliotecários aplicam às histórias em quadrinhos a velha máxima: "de graça, até injeção na testa"...);

- os quadrinhos são destinados apenas para uso de categorias específicas de usuários, como crianças ou estudantes de primeiro e segundo graus; alguns funcionários de biblioteca assumem até mesmo uma atitude desdenhosa quando algum adulto se interessa por revistas em quadrinhos;

- utilização das histórias em quadrinhos como chamariz para a leitura de livros, classificadas como uma espécie de concessão dos profissionais do livro (os bibliotecários) a uma leitura menos nobre (os gibis).

A possível desativação do espaço de leitura de histórias em quadrinhos também preocupou artistas e frequentadores da Gibiteca Municipal de Santos, resultando na confecção de uma carta aberta aos políticos locais solicitando o compromisso da manutenção do local, em agosto de 2016.

Em 2017 não foi diferente: o anúncio de que o coordenador da Gibiteca estaria se desligando de suas funções causou novamente comoção entre os cartunistas de Santos e região, gerando, mais uma vez, a possibilidade de fechamento do local (Figura 1): 
Figura 1 - Nota publicada na coluna Dia a Dia do jornal A Tribuna

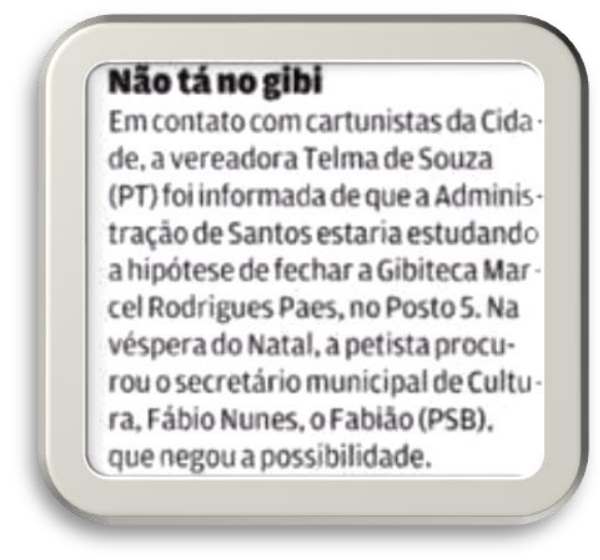

Fonte: Jornal A Tribuna-29 dez. 2017

Hoje, além de manter um acervo de mais de 30.000 exemplares, a Gibiteca de Santos é o ponto de encontro de produtores e fãs de quadrinhos para exposições e debates, além de ser um local para realização de outras atividades artísticas ou relacionadas à leitura, como contação de histórias e oficinas de desenho e fanzines.

Havia então, na época do processo seletivo para o mestrado, uma grande motivação para a realização desta pesquisa, que era divulgar a experiência vivida na Gibiteca de Santos e demonstrar que estes locais, se bem geridos e utilizados, podem representar muito mais que meros depósitos de revistas em quadrinhos. Para Severo (2012, p.56), além da atenção dispensada às coleções encontradas em uma gibiteca, os responsáveis pelo lugar devem também "dinamizar o espaço por meio de atividades vinculadas com o tipo de documentos que disponibilizam". Especificamente no caso da Gibiteca Marcel Rodrigues Paes, ela representa um ponto de encontro para uma rede de amigos que se formou a partir da participação e frequência nos eventos ali realizados, possibilitando aos seus visitantes não só aperfeiçoamento técnico de desenho e produção de quadrinhos, como acesso a obras de artistas que não são divulgados na grande mídia.

Não só isso: a Gibiteca de Santos não dispõe de recursos financeiros para custear os eventos, professores e artistas. Eventualmente, a Secretaria de Cultura disponibiliza um cachê que é usado para pagar os professores de desenho e artes, mas a grande maioria das pessoas cede um pouco do seu tempo à Gibiteca por amor aos quadrinhos. Por isso, registrar a forma como estas ações ocorrem poderia inspirar outros espaços similares a fazerem o mesmo. 


\section{Hipótese}

Tendo em vista a minha frequência aos eventos realizados pela Gibiteca de Santos e as considerações de colegas acadêmicos, educadores e gestores sobre o fechamento de gibitecas em diversos lugares do Brasil, foi possível observar que existem diversos fatores para a não continuidade das atividades desses espaços, sejam eles escolares ou não. Além da falta de interesse de muitos bibliotecários, há a dificuldade de catalogação, aquisição e manutenção das revistas em quadrinhos, que costumam ser mais frágeis que grande parte dos livros de um acervo de biblioteca pública.

Porém, para Scott (1991), uma forma de evitar que gibitecas sejam fechadas, seria por meio da demonstração de que esses espaços estão sendo frequentados e seus itens, pesquisados.

Assim, a partir da observação sobre a frequência dos visitantes à Gibiteca de Santos nos dias em que são realizados cursos ou outras atividades, levanta-se a hipótese de que a realização de eventos relacionados a histórias em quadrinhos e cultura pop pode garantir não só maior contato da população local com as revistas em quadrinhos, como, também, fomentar a produção cultural por meio das exposições dos artistas locais e quadrinistas nacionais e internacionais, dos cursos oferecidos e da troca e doação constante de revistas.

\section{Objetivo geral}

Demonstrar que gibitecas são espaços cuja função vai além de servir como um depósito de histórias em quadrinhos, podendo ser compreendidas como locais de socialização, significação de conteúdo, fomento à cultura e de exercício da cidadania. 


\section{Objetivos específicos}

- Justificar a existência das gibitecas por meio de considerações do que os teóricos da área dos Estudos Culturais e de Comunicação apontam sobre as histórias em quadrinhos e sua importância como bens culturais;

- Destacar eventos ocorridos em uma gibiteca específica - a Gibiteca Municipal de Santos - que possam ilustrar os discursos do quadro referencial teórico quanto à relevância de eventos sociais e culturais;

- Avaliar de que forma os eventos ocorridos na Gibiteca entre os anos de 2013 e 2016 contribuem para a formação de leitores de histórias em quadrinhos e de artistas na região da baixada santista.

\section{Metodologia e fundamentação teórica}

Jesus Martin-Barbero (2000) acredita que a mensuração dos efeitos que envolvem os fenômenos comunicacionais não deve se limitar aos estudos apenas dos meios, pois é no cotidiano dos eventos sociais, nos ambientes, que a comunicação realmente acontece: "Tentar medir a importância dos meios em si mesmos, sem levar em conta toda essa bagagem de mundo, de vida, da gente, é estar falsificando a vida para que caiba no modelo dos estudos dos meios" (MARTIN-BARBERO, 2000, p. 154).

A partir da perspectiva de Martin-Barbero (2000) sobre a importância desses eventos sociais e o papel que a comunicação desempenha em suas realizações, juntamente com as considerações de teóricos dos Estudos Culturais como Raymond Williams (2008) e Stuart Hall (2004), foi possível relacionar a reflexão acadêmica com as observações realizadas durante os eventos que ocorrem na Gibiteca Municipal de Santos.

A participação nas disciplinas cursadas no programa de pós-graduação propiciou que mais teorias e abordagens fossem oferecidas pelos professores, ampliando então as possibilidades sobre o quadro teórico e as metodologias aplicadas. Assim, a compreensão de que os elementos culturais fazem parte de um sistema de significação (HALL, 2003, 2004; MATTELART; NEVEU, 2002, WILLIAMS, 2008) que compõem todo o tecido que 
entendemos como cultura (GEERTZ, 1989; MATTELART; NEVEU, 2002; WILLIAMS, 2008), servem de referências a partir das quais será possível verificar sua incidência nos eventos realizados na Gibiteca Municipal de Santos entre os anos de 2013 e 2016.

Matthew Pustz (2000) acredita que os estudos acadêmicos sobre o público consumidor de cultura pop indicam que grupos de fãs frequentemente compartilham uma cultura comum sobre seus personagens ou produtos favoritos, além de falarem uma linguagem específica e partilharem das mesmas comunidades interpretativas, sustentando uma identidade comum. Assim, seu livro Comic Book Culture: fanboys and true believers também contribui para que a fundamentação teórica acerca dos elementos culturais considere os elementos comuns partilhados por fãs e leitores de histórias em quadrinhos.

Como destacam Mattelart e Neveu (2002), a genealogia dos Estudos Culturais está diretamente atrelada ao desejo de pesquisadores das Ciências Sociais de buscar soluções para desigualdades observadas em diversas sociedades, ou seja, a contrapartida social foi um fator significativo para o desenvolvimento de campos de estudo relacionados à cultura e à comunicação.

A partir dos anos 1960, com a contribuição de pesquisadores como Stuart Hall, teorias da Comunicação e dos Estudos Culturais começaram a ser desenvolvidas com um olhar na América Latina, confirmando que contextos diferentes necessitam de abordagens diferentes para que possam ser interpretados. Se muito do que havia sido produzido até os anos 1970 tinha como principais contribuições os conceitos desenvolvidos por Adorno e Gramsci, com o surgimento de escolas de Comunicação, entre elas a própria ECA, os estudos desenvolvidos na América Latina e no Brasil trouxeram perspectivas que favoreciam a compreensão de fenômenos ocorridos em nosso continente e que nem sempre podiam ser interpretados à luz das teorias até então vigentes.

Sem negar a importância dos meios, tema tão caro à Comunicação, Martin-Barbero ressalta a importância da comunicação que ocorre nos eventos sociais na América Latina, lembrando que a "cultura não é apenas o que a Sociologia chama de cultura" e não é limitada às práticas relacionadas às Belas Artes e Belas Letras (MARTIN-BARBERO, 2000, p. 154), mas é diversa e produzida diariamente na vida cotidiana, no teatro, nos espaços de convívio.

Valéria Bari (2008), em sua tese de doutorado sobre o potencial das histórias em quadrinhos na formação de público leitor, recorreu a gibitecas do Brasil e da Espanha no 
intuito de apontar contrapontos culturais entre os dois países. Ao legitimar a importância dos quadrinhos para o processo de leitura, automaticamente justifica a existência das gibitecas para que esse processo ocorra e, por isso, suas considerações são de fundamental importância para registrar um ponto de partida, de onde é possível expandir a ideia de gibitecas como espaços para a leitura exclusiva de histórias em quadrinhos por crianças e adolescentes, para espaços de socialização entre pessoas de diversas idades em torno de um interesse comum.

Natania Nogueira $(2007,2017)$ tem experiência de mais de 10 anos em implementação e manutenção de gibitecas escolares na cidade de Leopoldina, MG. Sua vivência demonstra que não só os jovens se integram melhor às atividades realizadas nas escolas após a criação de uma gibiteca, como também se sentem responsáveis pela manutenção de um espaço que se torna um dos lugares mais utilizados para sua socialização. A perspectiva, de que as histórias em quadrinhos podem propiciar desenvolvimento pedagógico, ao mesmo tempo em que funcionam como uma atividade de lazer é compartilhada por outros autores:

\begin{abstract}
Nos mais recentes aportes dos estudos culturais, estudiosos como Nestor Garcia Canclini elencam histórias em quadrinhos como bens culturais de vital importância para a cultura. Através desta reconciliação, foi possível a uma comunidade internacional de pesquisadores da pedagogia neo-piagetiana inserir, finalmente, as histórias em quadrinhos nas práticas pedagógicas. (BARI, 2008, p.157)
\end{abstract}

A obra de Nestor Canclini pode ser indicada a quem deseja entender os processos culturais ocorridos na América Latina, pois suas considerações acerca da importância da cultura de massa como fator de integração cultural, capaz inclusive de promover tomada de decisões referentes às políticas públicas (CANCLINI, 1997), nos apontam que, independentemente do tipo de atribuição de valor que possa ser conferida às histórias em quadrinhos, seu papel cultural não deve ser ignorado.

Quanto à metodologia empregada na pesquisa, trata-se de um estudo de caso com observação participativa e etnográfica. A etnografia é uma metodologia voltada para análises sobre as interações sociais, culturais e comportamentais. Levando-se em consideração o ambiente a ser analisado e suas relações com os atores envolvidos nos 
eventos oferecidos por ele, o estudo de caso é indicado e pode ser realizado por meio de técnicas como coleta de dados sobre os acontecimentos e número de visitantes e observação participativa, para que se obtenha informações sobre a relação de um fenômeno e seu contexto. A descrição etnográfica é interpretativa: o que ela interpreta é o fluxo do discurso social e a interpretação envolvida consiste em tentar salvar o "dito" num tal discurso de sua possibilidade de extinguir-se e fixa-lo em formas pesquisáveis. (GEERTZ, 1989, p. 15)

Com enfoque em eventos contemporâneos, o estudo de caso costuma ser aplicado em áreas da Ciência da Informação, em pesquisas relacionadas a bibliotecas, por exemplo. Normalmente indicado quando a compreensão dos processos sociais em seu contexto organizacional ou ambiental é importante para a pesquisa ou, na captura de aspectos emergentes de uma organização onde apenas uma pesquisa quantitativa seria muito estática para demonstrar o fluxo de atividades da organização. Assim,

\footnotetext{
o método de estudo de caso é um método específico de pesquisa de campo. Estudos de campo são investigações de fenômenos à medida que ocorrem, sem qualquer interferência significativa do pesquisador. Seu objetivo é compreender o evento em estudo e ao mesmo tempo desenvolver teorias mais genéricas a respeito dos aspectos característicos do fenômeno observado. (FIDEL, 1992 apud MORESI, 2003, p.102)
}

Entrevistas realizadas a partir de um questionário disponibilizado online entre os meses de agosto de 2017 e maio de 2018, e presencialmente na Gibiteca em 17 de dezembro de 2017, além de depoimentos de pesquisadores e cartunistas que frequentam o local há mais de 10 anos, colhidos via e-mail em 2017, indicam qual a relação que seus frequentadores têm com o local e suas atividades, fornecendo subsídios para ilustrar as considerações dos teóricos elencados na pesquisa e sustentar as informações contidas nos documentos que demonstram os dados quantitativos apresentados.

Além das informações do arquivo de matérias de jornais e outros itens disponíveis na Gibiteca, entre os meses de julho e dezembro de 2017 foram colhidos depoimentos de artistas e editores de quadrinhos, como o próprio Maurício de Sousa, em um vídeo ${ }^{3} \mathrm{em}$ homenagem ao aniversário de 25 anos da Gibiteca de Santos. Nesse vídeo, disponível

\footnotetext{
${ }^{3} \mathrm{https}: / /$ www.youtube.com/watch?v=8I9y_1zD_1k
} 
online, os convidados expressam suas considerações sobre a importância da Gibiteca para a cidade e para sua formação profissional também.

Entre as abordagens usadas para a compreensão dos dados coletados em um estudo de caso, a interpretativa oferece a possibilidade de entender o mundo do ponto de vista daqueles que o vivenciam; por isso, o objeto de pesquisa é entendido como construído socialmente pelos atores. Nesse processo, os atores envolvidos moldam significados a partir de eventos e fenômenos longos de interação social (SCHWANDT, 1994).

De acordo com Orlikowski e Baroudi (1991), na perspectiva dos estudos interpretativos a intenção do pesquisador é ampliar seu entendimento sobre o fenômeno em situações sociais e culturais, onde este é examinado em seu local de ocorrência e a partir das perspectivas dos participantes.

Bari (2008, p. 19), ao citar os estudos antropológicos que envolvem a "pesquisa participante" nos trabalhos de campo, explica que entre as responsabilidades do pesquisador está o papel de articulador entre o conhecimento teórico e o conhecimento concreto das situações cotidianas, ou seja, cabe ao pesquisador participar de tais práticas, observando, quantificando e qualificando todo o processo. Para Hall (2003), a análise dos elementos culturais envolvidos em determinados processos começa com a descoberta de padrões característicos. "Iremos descobri-los não na arte, produção, comércio, política, criação de filhos, tratados como atividades isoladas, mas através do estudo da organização geral em um caso particular" (HALL, 2003, p. 128).

Um processo de aprendizagem sobre uma determinada realidade, tem como principal objetivo funcionar como uma ação dirigida para aumentar a capacidade de ação diante de uma situação específica. Nesse sentido, tendo em mente as escolhas feitas em relação à metodologia de pesquisa, a hermenêutica, como um modo de análise dos dados coletados na pesquisa, irá fornecer os recursos necessários para a interpretação dessas informações. Composta por registros dos eventos na mídia, cadernos de assinaturas dos participantes, fotos dos eventos realizados, a documentação vem sendo coletada desde 2013, ainda que não houvesse a consciência da realização do mestrado.

O registro das atividades é feito pelos funcionários por meio da plataforma de tarefas Trello e, anualmente, um relatório com todos os dados de cada evento é divulgado durante a festa de aniversário, em dezembro. Estes dados são públicos e disponibilizados pelo Diário Oficial da cidade e para os presentes na festa, porém, além dos dados oficiais, 
há pelo menos três anos estes eventos vinham sendo divulgados em publicações em um site especializado em histórias em quadrinhos, o Quadro-a-Quadro ${ }^{4}$. Além desses registros, desde agosto de 2016, com acesso à plataforma Trello, o envolvimento com a programação e divulgação dos eventos se deu de forma mais ativa.

Gibitecas são objetos mais contumazes dos estudos de Biblioteconomia, principalmente quanto à organização e indexação de suas coleções. Em uma pesquisa realizada no site de buscas acadêmicas do Google no dia 11 de abril de 2017, verificou-se que grande parte dos 137 resultados está relacionada ao uso pedagógico desses espaços ou à formação de leitor. Já em relação aos livros dedicados ao tema, o que se observa é que, no montante de títulos analisados, não existam publicações sobre a importância das gibitecas e sua utilização nas escolas como espaço de aprendizagem. Na última década, várias pesquisas acadêmicas e relatos de experiências envolvendo gibitecas demonstraram o interesse de educadores e pesquisadores de outras áreas pelos efeitos das histórias em quadrinhos em sala de aula (MARINO; NOGUEIRA, 2016, p. 68); no entanto, pouco se fala sobre a importância das gibitecas em si, como espaços que sirvam de mediadores entre as atividades realizadas em sala e o acesso aos quadrinhos. Logo, para que o diálogo entre a pesquisa sobre coleções e quadrinhos e a pesquisa sobre os efeitos pedagógicos da leitura das histórias ocorra, é preciso que haja o reconhecimento de que a aquisição de significados e a mediação do conhecimento podem acontecer nos espaços onde os quadrinhos são mantidos, como nas gibitecas.

\section{A estrutura do trabalho}

A dissertação está estruturada em quatro capítulos e as considerações finais, assim delimitados:

1 - Entendendo que o acesso à cultura é um direito básico de todos os cidadãos e que por meio dela as pessoas aprimoram seus conhecimentos, desenvolvem maior sensibilidade a assuntos diversos e exercem sua cidadania, em Cultura, Cidadania e as Gibitecas são abordados conceitos de cultura e cidadania que possam sustentar a ideia de

4 http://quadro-a-quadro.blog.br/ 
que não só os quadrinhos seriam bens culturais, como, por meio dos eventos atrelados a eles, as pessoas teriam a possibilidade de ressignificar suas experiências como previsto nos apontamentos dos autores elencados neste capítulo. A necessidade de estabelecer os conceitos de cultura e cidadania que norteiam esta pesquisa parte do princípio de que, para definirmos o papel cultural dos quadrinhos e sua função social relacionada ao exercício da cidadania, é preciso definir os parâmetros dentro dos quais os quadrinhos podem ser considerados bens culturais e esclarecer porque os eventos que promovem sua divulgação representam uma forma de fomentar um determinado tipo de manifestação artística em certas comunidades.

2 - Em Histórias em Quadrinhos buscamos situar o leitor acerca do papel destas publicações ao longo da História, narrando sua trajetória, além de contextualizar a ideia que sugere que seu valor cultural é tão relevante quanto o de qualquer expressão artística. Para isso, recorremos a diversos autores que analisam a forma como os quadrinhos alcançaram status de Arte a partir de um processo de legitimação que, embora não concluído, tem sido responsável para que as histórias em quadrinhos deixem de ser vistas como um subproduto da literatura ou das artes visuais para se tornarem um campo de produção cultural específico, como aponta Carvalho (2017).

3 -Ao tratar das gibitecas no capítulo de mesmo título, buscamos pontuar sua importância em diversos âmbitos, como a formação de leitores e aquisição de conhecimentos diversos, e demonstrar que, apesar da tendência que indica o fechamento de muitos espaços dedicados exclusivamente à leitura de quadrinhos, o aumento na quantidade delas no país é atestado pelos autores mencionados nesse capítulo.

4 - A partir do estudo de caso da Gibiteca Municipal de Santos e dos eventos realizados no local, entre os anos de 2013 e 2016, procuramos ilustrar as falas dos autores como Mathew Pustz (2000) e Jesus Martin-Barbero (2000) quanto à necessidade de estes espaços existirem a partir da compreensão sobre cultura e cidadania, trazida no primeiro capítulo. Para isso, são detalhados os tipos de eventos ocorridos no período mencionado e trazidas análises das respostas do questionário disponibilizado online, além de considerações de alguns frequentadores assíduos do local para que possam corroborar os autores elencados sobre a relevância da realização dos eventos relacionados aos quadrinhos que são oferecidos pela Gibiteca. 
Considerações finais - A partir das discussões desenvolvidas ao longo dos capítulos, são apresentadas as considerações em relação aos objetivos pretendidos e comprovação/refutação da hipótese levantada. 


\section{1 - CULTURA, CIDADANIA E AS GIBITECAS}

\subsection{Conceitos de cultura}

Definir cultura, ainda que o termo continue em constante construção e não possa ser encerrado em conceitos que se pretendem absolutos, é essencial para nortear uma pesquisa que é pautada na ideia de que não só as histórias em quadrinhos constituem um patrimônio cultural significativo e relevante, mas, também, que o acesso a elas, e ao contexto em que são produzidas, representa um meio de exercer a cidadania em determinados espaços.

Ainda que não haja uma escassez real de estudos acerca da cultura, existe uma falta de estudos que a relacione com outros tópicos, ou seja, existe uma tendência de encará-la como um agrupamento indefinido de estudos de especialistas (WILLIAMS,2008, p. 9), quando, na verdade, sua concepção deveria ser mais ampla e no sentido de explorar seu aspecto convergente de vários elementos sociais. Isso não substituiria as noções mais específicas, desde que pudessem indicar as relações complexas do que seria um "sistema de significações" (WILLIAMS, 2008, p.206).

Tendo as considerações de Williams em mente, é possível pensar na transdisciplinaridade que os produtos de cultura pop oferecem em termos pedagógicos. Assim, as relações entre produtos diferentes, como filmes e quadrinhos, poderiam ser analisadas a partir de uma perspectiva histórica, por exemplo, o que já ocorre em eventos acadêmicos voltados ao estudo de quadrinhos, cujos anais ilustram essa convergência de temas, aplicações, perspectivas e vieses.

Embora o termo "cultura pop" seja amplamente usado no meio do entretenimento, a noção do que seria uma cultura popular nunca foi muito clara. De acordo com Scott (1991), o termo "cultura popular" surgiu em oposição a uma rigidez canônica que previa que apenas certos temas fossem tratados academicamente, entre os quais, os quadrinhos não estavam inseridos: 
O termo nunca teve fronteiras coerentes, e alguns estudiosos de "cultura popular" teriam sido pressionados a concordar com uma definição utilitária. Devido ao fato de a categoria ter sido criada em reação a um cânone rígido, seu conceito é essencialmente negativo. Chegou a ser progressista ao ponto de permitir que acadêmicos pudessem seguir em direção a uma democratização do objeto em questão. O estudo de cultura popular foi um movimento acadêmico como a "pop art" foi um movimento artístico e ambos podem ser tratados como históricos. (SCOTT, 1991, p. 18, tradução nossa ${ }^{5}$ )

Nesse sentido, Scott (1991) afirma que há um termo mais atual para essa área: Estudos Culturais. "Os Estudos Culturais parecem ser uma forma de estudar as preocupações do dia-a-dia das pessoas comuns" (SCOTT, 1991, p.18). Por isso, o autor acredita ser fundamental que as bibliotecas reconheçam o fato de que os meios de comunicação têm propiciado uma democratização da cultura e coletar dados a respeito dessas mudanças, deveria ser uma preocupação dos espaços voltados à pesquisa acadêmica, como as bibliotecas universitárias e especializadas.

Então, entendendo que os espaços onde são realizados eventos culturais ou que promovem acesso à cultura por meio de exposições, concertos, apresentações, são também espaços de significação e aquisição de sentidos, um polo de fomento à cultura seria qualquer espaço dedicado à realização desses eventos, onde o público tenha livre acesso a obras ou performances que propiciem sua aproximação com as mais diversas expressões artísticas.

Para Albuquerque (2004, p. 23-25), eventos seriam também fontes geradoras de divisas, uma forma de "divulgar os atrativos turísticos locais e gerar uma cadeia produtiva ao seu redor". Se pensarmos que os autores convidados levam seus quadrinhos para serem vendidos durante os eventos realizados, a Gibiteca poderia representar um ponto de vendas fixo para quem deseja divulgar seu trabalho, confirmando seu potencial como participante dessa cadeia produtiva e geradora de divisas, ao menos para os artistas nacionais.

Espaços que realizam eventos culturais são compreendidos como de espaços de mediação e aquisição de conhecimentos e saberes por determinados grupos na concepção

\footnotetext{
${ }^{5}$ The term never had coherent boundaries, and any two "popular culture" scholars would have been hard pressed to agree on a useful definition. Because the category was created in reaction to a rigid canon, it is essentially a negative concept. It was once progressive in that it allowed academics to move forward in the direction of democratization of subject matter. Popular culture studies was na academic movement, like "pop art" was an artistic movement, and both can be treated as historical.
} 
de alguns estudiosos de Geografia Cultural, como aponta Cortez (2013) ao elencar uma série de autores da mesma linha:

A cultura resulta da capacidade de os seres humanos se comunicarem entre si por meio de símbolos. A construção dessa relação mediada pela comunicação demonstra a centralidade da questão espacial para o entendimento da cultura, que pode ser também compreendida como o espaço intersubjetivo no interior do qual símbolos e práticas são capazes de serem elaborados, transmitidos e partilhados. Mas sabemos que não é o espaço geográfico que limita as fronteiras da cultura. Quando se tem condições de expandir esses espaços através da capacidade da circulação de ideias e objetos, num processo de reelaboração e partilhamento simbólico, o espaço cultural se expande. (CORTEZ, 2013, p. 200)

As produções artísticas são expostas a partir de um sistema de sinais determinado pela ocasião e lugar que se convenciona serem apropriados. Por isso, uma mesma produção demonstraria sinais específicos de apresentação dependendo do lugar onde se encontra. Por exemplo, uma peça teatral apresentada em um teatro é associada a sinais como as cortinas, a disposição das cadeiras, horários... A mesma peça apresentada em um programa de televisão será marcada por sinais distintos, característicos do ambiente encontrado em uma emissora de televisão. Ou seja, os espaços seriam responsáveis por ditar que tipos de sinais podem ser associados a determinada representação artística (WILLIAMS, 2008, p. 131). Em relação aos espaços dedicados à leitura de histórias em quadrinhos, podemos inferir, a partir da perspectiva de Williams, que também apresentariam sinais e elementos específicos que constituem um sistema de significados exclusivos, partilhados pelos grupos que os frequentam.

No caso de uma gibiteca, estes sinais são caracterizados pela presença de elementos pertinentes à cultura das histórias em quadrinhos, como a existência de estantes repletas de revistas em quadrinhos, a disposição das mesas e cadeiras disponíveis para leitura, a presença de um especialista capaz de indicar a localização de um determinado exemplar ou em qual arco um personagem realizou determinado feito.

Já na percepção de estudiosos da Geografia Cultural, como Cosgrove (2007), Wagner e Mikesell (2007 apud CORTEZ 2013), a frequência de visitantes em determinados lugares pode propiciar o surgimento de um espaço de interação entre os signos presentes e significados construídos previamente, gerando o consenso entre esses indivíduos socialmente organizados no decorrer de um processo de interação, como o que ocorre durante os eventos de quadrinhos na Gibiteca. 
Cortez (2013) acredita que a prática delimita o espaço dos signos que são comuns a uma coletividade e que, por isso, a linguagem estabeleceria uma geografia da interação de uma determinada cultura. "É nesse espaço cultural que se apresenta o espaço de comunicação, um ambiente que manifesta a cultura e é eminentemente ideológico, porque é o lugar das significações" (CORTEZ, 2013, p. 201). Esses espaços de significação podem ser representados pela mídia, escola, órgãos públicos e - por que não? -, pelas gibitecas também.

Esse consenso é estabelecido a partir da exposição de argumentos e da troca de conhecimentos que cada envolvido no processo possui, indicando que para que essa interação ocorra, os sinais característicos que compõem tanto uma produção cultural como o espaço onde ela é exposta, devem estar presentes para que o processo se dê adequadamente. Em outras palavras, a combinação dos sinais apontados por Williams (2008) com as características físicas de um espaço destinado à circulação de produtos culturais, geraria uma interação entre os visitantes que não poderia ser observada em qualquer outro ambiente que não aquele onde ela ocorre, ou seja, um bate-papo sobre o mercado editorial de quadrinhos brasileiro, se realizado em uma praça de alimentação de um shopping, poderia atrair as mesmas pessoas que frequentam uma gibiteca, mas poderia chamar a atenção de pessoas completamente alheias aos elementos constitutivos de uma cultura dos quadrinhos, gerando assim, uma interação entre pessoas que não possuem, necessariamente, interesses em comum.

O que se prioriza em cada uma dessas interações pode variar de acordo com as intenções de seus organizadores ou envolvidos, porém, no que tange aos estudiosos de cultura, essa intenção deveria passar pela busca constante de um diálogo que priorize, na visão de Bauman (2013), uma concepção comum de bem-estar.

Entretanto, a ideia de bem-estar está atrelada às questões subjetivas de nossa cultura e varia de acordo com o contexto onde está inserida. Na perspectiva de Cortez (2013, p.197), definir cultura de uma forma precisa implicaria justamente em reduzi-la a uma categoria objetiva, negando sua subjetividade essencial, que é inerente às interações humanas. Então, ao considerar os aspectos subjetivos da cultura, Cosgrove (2007) ressalta que 
os seres humanos, com sua realidade sensorial e material, experienciam e transformam o mundo natural através do engajamento direto. A produção e reprodução da vida material são, necessariamente, uma arte coletiva, mediada na consciência e sustentada através de códigos de comunicação. Esta última é produção simbólica. Tais códigos incluem não apenas a linguagem em seu sentido formal, mas também o gesto, o vestuário, a conduta pessoal e social, a música, a pintura, a dança, o ritual, a cerimônia e as construções. (COSGROVE, 2007, p. 33)

Refletindo sobre o conjunto de códigos pertinentes à comunicação de determinados grupos, como Cosgrove (2007) propõe, é possível elencar alguns desses códigos compartilhados pelos indivíduos presentes nos eventos de quadrinhos que ocorrem na Gibiteca, como por exemplo, o uso de camisetas de personagens de super-heróis (vestuário), o ato de colecionar "action figures" e outros itens de seus personagens favoritos (conduta social), a adoção de certos valores morais retratados nas histórias em quadrinhos (conduta pessoal) ou a citação de piadas que se relacionam com determinados conteúdos (linguagem), reforçando o que Pustz (2000) afirma quanto à existência de uma cultura específica das histórias em quadrinhos.

Para Hall (2013, p.135), a “cultura é a soma das descrições disponíveis pelas quais as sociedades dão sentido e refletem as suas experiências comuns" e o propósito de sua análise é entender como as inter-relações de todas as práticas e padrões são vividas e experimentadas como um todo em um dado período, ou seja, assim como Martin-Barbero (2000), Hall considera que "a cultura não é uma prática; nem apenas a soma descritiva dos costumes e culturas populares das sociedades, como ela tende a se tornar em certos tipos de antropologia". Logo, todas as práticas sociais constituem a soma do interrelacionamento dos agentes que compõem um determinado grupo (HALL, 2003, p.136) e é essa relação que muito interessa aos Estudos Culturais e de Comunicação. Portanto,

cultura é o conjunto de sentidos e valores que nascem entre as classes e grupos sociais diferentes, com base em suas relações e condições históricas, pelas quais eles lidam com suas condições de existência e respondem a estas; e também como as tradições e práticas vividas através das quais esses "entendimentos "são expressos e nos quais são incorporados. (HALL, 2003, p.142)

Assim, diante das diversas possibilidades sob a qual a cultura pode ser analisada e interpretada, uma das definições de Williams (1961) abarca de forma mais abrangente a 
ideia de que a cultura não é um bloco monolítico que contempla todas as práticas sociais de um país ou território, mas uma prática compartilhada por integrantes de um determinado grupo. De acordo com ele,

a nossa maneira de ver as coisas é literalmente nossa maneira de viver, o processo de comunicação, de fato é o processo de comunhão: o compartilhamento de significados comuns e, daí, os propósitos e atividades comuns; a oferta, recepção e comparação de novos significados, que levam a tensões, ao crescimento e à mudança. (WILLIAMS, 1961, p.55)

Então, é possível considerar a organização social da cultura, "como um sistema de significações realizado, que está embutido em uma série completa de atividades, relações e instituições" (WILLIAMS, 2008, p. 208). Este sistema, varia de acordo com o contexto em que está inserido, por isso, não seria indicado tentar interpretar culturas diversas a partir de fórmulas, sob uma perspectiva absolutista. Sendo assim, a contribuição de autores como Stuart Hall, Nestor Canclini, Jesus Martin-Barbero e do próprio Raymond Williams, está no fato de terem definido que culturas diferentes precisam de abordagens diferentes para que possam ser interpretadas, pois cada manifestação apresenta resultados particulares que valem a pena serem observados sob a ótica dos Estudos Culturais, como é o caso das gibitecas e das interações que ocorrem em seu interior.

\subsection{Acesso à cultura como um meio de exercer a cidadania}

Para o sociólogo T. H. Marshall (1967, p.62), a questão da cidadania estaria relacionada às condições igualitárias de acesso à cultura por todos os cidadãos de uma comunidade, ainda que existam desigualdades sociais, ou seja, existiria "uma espécie de igualdade humana básica associada com o conceito de participação integral na comunidade". Dessa forma, ainda que pessoas possam pertencer a classes sociais diferentes, os espaços públicos propiciariam contato com obras que muitas pessoas não podem adquirir, democratizando assim, o acesso à cultura e seus produtos.

Então, a cidadania estaria atrelada, entre outras coisas, à ocupação de certos espaços por eventos e produções culturais, o que para os estudiosos da Geografia Cultural (CORTEZ, p.197, 2013) forneceria subsídios para compreender essa relação entre a 
atividade comunicacional (um bate-papo sobre quadrinhos), simbólica (conteúdo específico pertinente aos quadrinhos partilhado por seus leitores) e material (as revistas em quadrinhos).

Na perspectiva defendida por T. H Marshall (1967) de que o conceito de cidadania não pode ser compreendido sem uma contextualização histórica dos direitos civis, ele afirma que quando a liberdade se tornou um valor universal, no início do século XIX, a cidadania se transformou de uma instituição local para uma nacional, ganhando destaque em legislações de diversos países. Por isso, Michael Curtin (2015) propõe que além dos estudos, políticas públicas deveriam enfatizar o uso de recursos culturais pela comunidade, uma vez que estes recursos tornariam os lugares melhores para se viver, ou seja, o acesso aos eventos e à produção cultural como uma forma de aquisição de novos conhecimentos, seria uma maneira de exercitar a cidadania por meio da participação e frequência nesses espaços, como um dos direitos básicos garantidos constitucionalmente.

Essas práticas sugeridas por Curtin (2015) podem ser observadas em outros equipamentos culturais da cidade de Santos, que, assim como a Gibiteca, constituem espaços para apreciação de bens culturais: No Museu do Café, localizado no antigo prédio da Bolsa Oficial de Café, funciona uma cafeteria com seleções especiais de diversos grãos brasileiros e que é frequentada durante toda a semana por pessoas que trabalham no centro da cidade e por escolas e grupos de turistas previamente agendados. O museu oferece aos visitantes a exposição de materiais que eram usados na produção de café no auge de sua produção no Brasil, bem como pinturas de Benedicto Calixto, que retratava a paisagem da cidade no passado. Nos finais de semana, o local oferece apresentações musicais e cursos sobre café e ao longo da semana, também abriga exposições diversas, como a exposição itinerante do Museu da Língua Portuguesa.

Marshall (1967, p. 83) afirma que a sociedade, no final do século XIX, vivenciou o interesse crescente pela igualdade como um princípio de justiça social e uma consciência do fato de que o reconhecimento formal de uma capacidade igual no que diz respeito a direitos não era suficiente. Nesse sentido, é compreensível que se faça uma conexão com as considerações de Mattelart e Neveu (2002), quando justificam o surgimento dos Estudos Culturais a partir de uma necessidade de cientistas sociais de procurar respostas para problemas ligados a desigualdades que tinham em seu cerne questões ligadas à cultura, como uma forma de buscar resolver desequilíbrios muitas 
vezes associados a uma visão marxista, sobre muitas dessas desigualdades serem causadas por questões ligadas às classes sociais.

Para Cortez (2013, p. 203), a prática cultural se expressa em rituais, comportamentos, produtos, cotidianos, serviços e outras atividades que materializam as ideias e a ideologia, que se manifestam por meio de significações e representações comuns aos indivíduos que partilhavam desses lugares. Assim, quanto à leitura de quadrinhos como uma prática cultural, podemos dizer que elas

\begin{abstract}
cumprem, nas ações de renovação do papel social da leitura, a função de apresentar um texto altamente informativo e ao mesmo tempo conciso, onde o leitor usufrui da leitura e amadurece, abrindo as portas da mente para o que lhe vai ser agora ofertado: a garantia social de acesso aos bens culturais bibliográficos. Além da leitura convidativa, também são interessantes as características da posse ou consumo das histórias em quadrinhos, em que quase sempre são incluídas relações de pertencimento a determinadas comunidades. Ou, seja, ler regularmente as histórias em quadrinhos também significa a participação social em uma comunidade, que vincula seus membros por meio de uma prática leitora e, por isso, favorece indiretamente a educação formal, informal e não formal. (BARI, 2008, p. 116)
\end{abstract}

Por meio da participação em eventos ou de visitação de espaços destinados à exposição de produtos culturais, os indivíduos podem dispor de elementos para construir sua identidade cultural e, para Cuche (2002, p.182), "a construção da identidade se faz no interior de contextos sociais que determinam a posição dos agentes e por isso mesmo orientam suas representações e suas escolhas". Essas escolhas, feitas pelos atores que integram um determinado grupo e compartilham certos valores culturais, resultariam na construção de uma identidade cultural, pois são dotadas de eficácia social, produzindo efeitos sociais reais. Entre esses efeitos estaria o uso de quadrinhos em sala de aula promovido por professores de diversas disciplinas que costumam frequentar a gibiteca, de acordo com depoimentos feitos por eles quando participaram de atividades no local $^{6}$.

Em relação aos espaços de lazer como espaços de convivência e compartilhamento de experiências, esses podem ser encontrados em museus, escolas, áreas públicas como praças e onde nem sempre a interação é incentivada, como bibliotecas. Logo, uma

\footnotetext{
${ }^{6}$ Depoimentos feitos em bate-papos diversos sobre histórias em quadrinhos. Entre os frequentadores que utilizam quadrinhos em sala de aula, pelo menos três deles fazem isso nas disciplinas de História, no Ensino Médio das escolas públicas.
} 
gibiteca, por manter em seus acervos um material que é muito associado ao entretenimento, poderia oferecer atividades que aproximem o público aos quadrinhos, propiciando o surgimento de núcleos interação social e aquisição de conhecimento, estabelecendo assim, seu papel como um agente de transformação social local. 


\section{AS HISTÓRIAS EM QUADRINHOS}

\subsection{As histórias em quadrinhos ao longo da História}

O surgimento dos quadrinhos como conhecemos hoje pode ser associado às publicações das tiras cômicas nos jornais americanos: Na última década do século XIX, Joseph Pulitzer e William Randolph Hearst, proprietários de jornais nos Estados Unidos, brigavam pela conquista de um público maior. Para atingirem uma massa semialfabetizada e os imigrantes, que tinham dificuldades com o inglês, criaram os suplementos dominicais. Foi num destes suplementos que surgiu, em 1895, o personagem de Richard Outcault, The Yellow kid (GOIDANICH, 1990, p. II). Já no Brasil, Bari afirma que,

sob a forma marginal dos pasquins, folhetos, panfletos, a narrativa gráfica brasileira resistiu e atravessou o século XIX, chegando com força e vigor ao século XX. A chegada do século XXI, contudo, não trouxe o mesmo êxito dos séculos anteriores já que, agregado ao problema do analfabetismo endêmico, a exclusão da grande maioria da população à fruição de bens culturais agora volta a vincular-se ao suporte. Muito embora não haja uma proibição política, a ausência de políticas públicas mantém grande parte da população excluída do universo digital, território imaterial onde transitam as mais largas estradas de formação, informação, cidadania e pertencimento social. (BARI, 2008, p. 32)

A resistência com que os quadrinhos eram vistos por pais e professores até pouco tempo atrás se deve ao código de censura aos quadrinhos (CCA), criado por editores nos anos 1950 por acreditarem que as histórias não só fomentavam o medo e a indisciplina, como corrompiam os jovens da época. Esta crença se devia à publicação do livro Seduction of the Innocent em 1954, de Fredric Wertham e que teve grande impacto na sociedade americana ao afirmar que as histórias de Batman, por exemplo, induziam os leitores ao homossexualismo, como explica Vergueiro: 
Pais e mestres desconfiavam das aventuras fantasiosas das páginas multicoloridas das $\mathrm{HQ}$, supondo que elas poderiam afastar crianças e jovens de leituras 'mais profundas', desviando-os assim de um amadurecimento 'sadio e responsável'. Daí, a entrada dos quadrinhos em sala de aula encontrou severas restrições, acabando por serem banidos, muitas vezes de forma até violenta, do ambiente escolar. Aos poucos, tais restrições foram atenuadas e extinguidas, mas não de forma tranquila, sendo na verdade resultado de uma longa e árdua jornada. (VERGUEIRO, 2009, p.8).

De acordo com Scott (1991, p.13), a associação dos quadrinhos com a delinquência juvenil nos anos 1940 e 1950 foi tão forte, que os prejuízos para a indústria dos quadrinhos podem ser sentidos até hoje.

Muito embora Wertham não tenha sido a única pessoa a se opor a produção de quadrinhos, em 1954 seu livro Seduction of the Innocent (Sedução do Inocente) foi eleito o melhor livro do ano pelo editor da revista da Associação Nacional de Educação, Joy Elmer Morgan, que o recomendou a pais, professores e bibliotecários ${ }^{7}$, e trazia duras críticas, além de pesquisas, que apontavam as histórias em quadrinhos como as grandes responsáveis pelo aumento da delinquência juvenil no período pós-guerra. Suas denúncias serviram como estopim para a instauração de diversas audiências presididas por membros do subcomitê de investigação da delinquência juvenil do senado americano, intimando psicólogos, pedagogos, especialistas em juventude e os responsáveis pelas maiores editoras de quadrinhos do país, que deram então origem ao Código dos Quadrinhos. Ainda que muitas edições não considerassem mais o código a partir dos anos 1970, quando Stan Lee criou histórias do Homem-Aranha que faziam menção ao abuso de drogas, forçando uma revisão dos padrões do CCA, ele só foi encerrado em 2011.

Em sua tese de doutorado, Valéria Bari (2008) realizou uma pesquisa abrangente sobre a história dos quadrinhos no Brasil. Como afirma a autora, o Brasil tem uma tradição de estudos das histórias em quadrinhos desde os anos 1960, de modo que repetir o que já vem sendo feito em diversos trabalhos acadêmicos seria redundante. Ainda assim, para fins de contextualização da pesquisa, uma breve passagem sobre os aspectos mais importantes no desenvolvimento deste tipo de manifestação cultural é feita no sentido de ilustrar a concepção de que histórias em quadrinhos são também bens culturais. Os estudos

\footnotetext{
7 “Joy Elmer Morgan, editor of the National Education Association's NEA Journal, selected it as the book of the year, recommending it to parents, teachers, and librarians" (TILLEY, 2012, p. 384 - tradução nossa)
} 
mencionados por Bari, vêm consolidando a tradição das linhas teóricas e núcleos de pesquisas especializados,

com produção científica de visibilidade, sob as auspiciosas aproximações teóricas dos estudos culturais da Escola de Birmingham. Muitas destas pesquisas, voltadas para as prementes necessidades de incremento cultural brasileiro, têm a temática voltada para a aplicabilidade das histórias em quadrinhos nas práticas educativas formais, informais e não formais, estabelecendo uma ponte real e de função extremamente importante entre a academia e a sociedade. (BARI, 2008, p. 13)

Existem divergências quanto qual produção poderia ser considerada a primeira narrativa sequencial da História, no entanto, o editor Rogério de Campos (2015) busca nos mostrar que existe uma ordem cronológica de aparecimento de certos tipos de narrativas que guardam características semelhantes às encontradas nas obras da Nona Arte.

Campos (2015) afirma que tentar determinar quem teria sido o inventor dos quadrinhos é algo sem sentido, uma vez que, como costuma ocorrer ao longo da História, muitas manifestações artísticas surgiram simultaneamente em lugares diferentes do globo. No caso dos quadrinhos, especificamente, apesar de muitos pesquisadores atribuírem à arte rupestre ou às narrativas egípcias características que poderiam enquadrá-las em um tipo de arte sequencial, o fato é que o surgimento da prensa gráfica pode ser considerado um grande marco para a consolidação das histórias em quadrinhos como conhecemos hoje.

Por isso, ao citar Yellow Kid, de Outcault, e Nhô Quim, de Angelo Agostini, Rogério de Campos informa que muitos outros autores já produziam quadrinhos não só nos Estados Unidos e Brasil, como em vários lugares do mundo. De qualquer forma, os quadrinhos tornaram-se mais populares no contexto do que Horkheimer e Adorno (MARTINBARBERO, 1997) cunharam de indústria cultural, entendidos como meios de comunicação de massa.

Sendo assim, tão difícil quanto determinar a origem exata das histórias em quadrinhos é determinar o que é uma história em quadrinhos, visto que o próprio conceito muda e evolui na medida que as narrativas se desenvolvem. Apesar disso, é possível relacionar Nona Arte com outras mídias, como o cinema: L'Arrouseur Arrosé, produzida pelos irmãos Lumiere em 1895 é uma adaptação de uma história em quadrinhos (Campos, 2015). 
Popularmente conhecida como "gibi”, a revista de história em quadrinhos no Brasil recebeu este nome em função da publicação mais popular do gênero nos anos 1940 (Figura 32): “Tão popular que acabou sendo utilizada para denominar, em uma relação de sinonímia, todas as revistas de histórias em quadrinhos publicadas no país" (VERGUEIRO, 1999).

Os nomes que os quadrinhos recebem em cada país costumam estar associados a algum elemento de sua composição. De acordo com Vergueiro (2005, p.1), nos países de língua inglesa, as histórias em quadrinhos são conhecidas como "comics", devido à associação com os aspectos cômicos das primeiras tiras publicadas nos jornais; para os franceses, "bandes dessinées", devido à forma como foram tradicionalmente publicados nos jornais, em forma de tira ("bande"); em português, a expressão "banda desenhada", foi incorporada pelos leitores de Portugal e algumas de suas ex-colônias, à exceção do Brasil; os espanhóis referem-se a elas como "tebeos", denominação derivada de uma popular revista dirigida a crianças e jovens, mas atualmente muitos se referem a elas como "cômicos"; nos países latinoamericanos, de uma maneira geral, são conhecidas como "historietas"; para os japoneses, "mangás"; já os italianos optaram pela expressão "fumetti", plural de "fumetto", termo que utilizam para se referir à figura onde estão contidas as falas e pensamentos dos personagens dos quadrinhos, que em português recebe o nome de "balão"; e no Brasil,

\begin{abstract}
depois de alguma controvérsia inicial sobre a utilização de "estórias" ou "histórias", parece ter consagrado a expressão "histórias em quadrinhos" (normalmente abreviada para "HQ") como a de maior preferência; no entanto, muitos leitores antigos e grande parte dos novos continuam ainda a utilizar o termo gibis quando se referem às revistas de histórias em quadrinhos de uma maneira geral, reproduzindo uma apropriação linguística semelhante à ocorrida no território espanhol, pois Gibi foi também uma popular revista de histórias em quadrinhos publicada no país. (VERGUEIRO, 2005, p. 2)
\end{abstract}

Podendo ser consideradas um dos meios de comunicação de massa mais populares do século XX, eram publicadas incialmente em jornais até o aparecimento das revistas em quadrinhos a partir dos anos 1930. Hoje, são publicadas aos milhões e em diversas formas e suportes no mundo todo (VERGUEIRO, 2005, p. 2).

Porém, devido ao aumento anual das publicações acadêmicas que vem sido verificado principalmente a partir de 2008 (MARINO; NOGUEIRA, 2016, p. 68), as 
histórias em quadrinhos têm sido estudadas a partir de diferentes perspectivas, ora como fonte, ora como objeto. Essa tendência pode ser observada no site das Jornadas Internacionais de Histórias em quadrinhos ${ }^{8}$, onde os históricos anuais registram não só a quantidade de resumos de artigos enviados, como também o número de lançamentos de livros acadêmicos sobre quadrinhos. Vergueiro e Santos (2006) fizeram um levantamento das publicações acadêmicas produzidas na Universidade de São Paulo entre os anos de 1972 e 2005 e constataram um aumento significativo no número de produções acadêmicas em diversas áreas do conhecimento. Já Callari e Gentil (2016, p. 17-18), mais recentemente, demonstraram em forma de gráfico como esse aumento pode ser percebido, indicando que foram encontrados três trabalhos na década de 1970 e 13 trabalhos entre 2000 e 2005, subindo para 81 entre 2010 e 2013, apenas na Universidade de São Paulo (CALLARI, GENTIL, 2016, p.17)

Com o surgimento do que conhecemos como "Graphic Novel" (DANNER; MAZUR, 2014), ou seja, publicações com qualidade gráfica superior em comparação aos formatos tradicionais e que muitas vezes trazem histórias não seriadas, podendo ser adquiridas em livrarias e lojas especializadas, algumas histórias foram "elevadas" ao status de obra literária, como ocorreu com um volume da adaptação Sonhos de Uma noite de Verão (1991) para o arco de Sandman, de Neil Gaiman, que foi a primeira revista em quadrinhos a receber o prêmio literário de melhor conto no World Fantasy Awards em $1991^{9}$, ou com o surgimento de uma categoria exclusiva de história em quadrinhos em prêmios literários como o Jabuti (Dois Irmãos, de Fábio Moon e Gabriel Bá, em 2016 e diversos outros títulos em 2017), ou premiadas em categoria especial no Pulitzer (Maus, de Art Spielgeman, em 1992):

Considerado um dos mais importantes quadrinistas da vanguarda
norte-americana (Spielgeman), recebeu em 1992 o Prêmio Pulitzer
- o mais importante do mercado editorial norte-americano -, em
uma categoria especial, por sua visão singular diante da tragédia
vivida por seus pais durante o Holocausto. (CARVALHO, 2017,
p.94)

Os estudos dos quadrinhos e suas aplicações em sala de aula podem ser conferidos em trabalhos, livros e artigos publicados por acadêmicos que têm se dedicado à pesquisa

\footnotetext{
${ }^{8}$ http://www2.eca.usp.br/jornadas/memoria_2011.php

${ }^{9} \mathrm{http} / / / \mathrm{www}$. worldfantasy.org/awards/nominees/
} 
há várias décadas. O Brasil, por exemplo, é o país que possui a disciplina universitária mais longeva voltada para o estudo desse tipo de arte sequencial, que existe continuamente desde o ano de 1972 e que pode ser cursada na Escola de Comunicações e Artes da Universidade de São Paulo (VERGUEIRO, 1994, p.15). De acordo com Vergueiro,

na medida em que as histórias em quadrinhos se tornaram um elemento de grande influência na cultura popular, também o interesse por elas aumentou em todas as áreas. Pesquisas acadêmicas sobre quadrinhos têm surgido nas áreas do conhecimento mais diversas, como história, sociologia, artes, literatura, antropologia, educação, etc., ampliando a disponibilidade de informações de qualidade sobre eles. Além disso, principalmente a partir do aparecimento da rede Internet, a quantidade de recursos informacionais existentes sobre a linguagem gráfica sequencial e seus produtos cresceu exponencialmente, variando enormemente em termos de forma, qualidade e conteúdo. (VERGUEIRO, 2005, p. 9)

Embora os PCN (Parâmetros Curriculares Nacionais) do Ensino de Língua Portuguesa sugiram o uso de adaptações literárias no ensino de Literatura para os ensinos fundamental e médio, bem como seu uso em atividades como murais, seminários, palestras, as possibilidades de aplicações das histórias em quadrinhos podem ser ilimitadas. Ainda assim, diante do preconceito do passado (VERGUEIRO; RAMOS, 2009), a presença dos quadrinhos nos PCN certamente significou um avanço para que sua aceitação fosse possível por educadores, uma vez que eles servem como guia das atividades escolares básicas a serem realizadas durante o ano letivo:

A análise de textos de diferentes gêneros (slogans, quadrinhos, poemas, notícias de jornal, anúncios publicitários, textos de manuais de instrução, entre outros), vazados em língua estrangeira, permite a consolidação do conceito e o reconhecimento de que um texto só se configura como tal a partir da articulação de determinados elementos, de uma intencionalidade, explícita ou não, e de um contexto moldado por variáveis socioculturais. (PCN Ensino Médio, p.96).

Considerar o processo de aceitação que as histórias em quadrinhos passaram dentro da educação (VERGUEIRO; RAMOS, 2009) é importante porque, como apontou Bari (2008), não só os quadrinhos ainda são fortemente associados ao letramento, como é a escola que tem o maior potencial de formação de leitores, tanto quanto os pais e familiares maiores: 
Considerando-se a inépcia das políticas públicas, que não disponibilizam a leitura pública e depositam a culpa de sua ausência no leitor potencial, não existem mais modelos sociais que induzam os jovens leitores aos esforços que precedem à formação leitora. Ou seja, não há o que imitar, não há referências visíveis, já que os familiares maiores e membros proeminentes da comunidade, ou mesmo os protagonistas midiáticos, não demonstram familiaridade com a leitura de lazer. (BARI, 2008, p. 115)

Ao refletir sobre a apropriação e significação cultural, Bari (2008, p. 113) afirma que, apesar de a produção e distribuição dos bens culturais serem massivas, a ressignificação é individualizada, ou seja, trata-se de um processo de formação pessoal que é constituído historicamente em âmbito pessoal, comunitário e local. "Dessa forma, a apropriação e os usos da leitura, cuja proficiência plena configura o letramento, são constituídas entre o "mundo do texto e o "mundo do leitor"”. (BARI, 2008, p.113). Ainda de acordo com Bari,

a linguagem dos quadrinhos foi amplamente utilizada no mundo como difusão de informações de utilidade pública. Porém, até recentemente, os bibliotecários e agentes culturais não conseguiam vislumbrar o valor artístico, educativo das histórias em quadrinhos, sob o fantasma da obra de Wertham, reforçado por todo o conjunto de teorias frankfurtianas. Nas últimas décadas do século XX, contudo, o crescimento em importância da Escola de Birmingham e dos estudos culturais fez com que estudiosos latino-americanos paulatinamente encarassem a história em quadrinhos como mais uma das manifestações culturais socialmente produzidas. (BARI, 2008, p. 11)

Essa apropriação também se articula em relação de posse ou consumo dos bens culturais vinculados à leitura, no entanto, a perda da significação do ato de ler, a "crise da leitura, documentada por vários países (BARI, 2008, p. 113) poderia ser mais relacionada à precariedade ou ausência de espaços públicos voltados para a leitura do que propriamente à falta de interesse ou gosto do cidadão comum, uma vez que, como apontam Nogueira (2007, 2017) ao longo de suas publicações e Bari (2008, 2012), a recepção das histórias em quadrinhos por parte de visitantes das gibitecas se mostrou sempre muito positiva. Não à toa, Canclini (2000) também reconhece o papel das histórias em quadrinhos como um importante elemento cultural: 
As histórias em quadrinhos se tornaram a tal ponto um componente central da cultura contemporânea, com uma bibliografia tão extensa, que seria trivial insistir no que todos sabemos de sua aliança inovadora, desde o final do sec. XIX, entre a cultura icônica e a literária. Participam da arte e do jornalismo, são a literatura mais lida, no ramo da indústria cultural que produz mais lucros. (...). Podemos lembrar que as histórias em quadrinhos, ao gerar novas técnicas narrativas, mediante a combinação original de tempo e imagem em um relato de quadros descontínuos, contribuíram para mostrar a potencialidade visual da escrita e do dramatismo que pode ser condensado em imagens estáticas. (CANCLINI, 2000, p. 339)

Ainda que o preconceito em relação às histórias em quadrinhos como bens culturais talvez não tenha sido totalmente superado, com o advento da internet e das redes sociais o cenário de produção de histórias em quadrinhos tem passado por mudanças significativas. De acordo com Ramos (2014), as primeiras experiências com tiras online no Brasil foram feitas por jornais em suas páginas online, a princípio usando o mesmo formato das páginas impressas, mas com as possibilidades oferecidas pelos espaços como sites e blogs, estes formatos passaram a ser mais variados.

Hoje, a variedade de publicações oferecidas online possibilita não só que os leitores possam escolher os temas que mais lhes agradem, como permite que os artistas ganhem maior visibilidade e acabem publicando seu material de forma impressa posteriormente, seja através de uma editora, de um edital ou através de sites colaborativos como o Catarse e o Kickante. Por meio desses sites, os artistas disponibilizam informações sobre o projeto que estão trabalhando e as pessoas contribuem com valores variados, até que o valor arrecadado alcance a meta estipulada pelo artista, para que ele consiga viabilizar a produção da sua história em quadrinhos, livro ou qualquer outro projeto artístico.

Entre outubro e novembro de 2011, Vitor Nicolau (2013) fez um levantamento de blogs que apresentavam tiras através de técnicas de análise de conteúdo. Naquela ocasião chegou à quantidade de 104. No entanto, dificilmente seria possível precisar a quantidade de quadrinhos publicados online hoje, visto que a cada dia novas páginas e formas de publicações surgem.

Os sites especializados, como Universo $H Q$ e Judão, se dedicam a divulgar os trabalhos de artistas nacionais. Eventos regionais como Festival Internacional de Quadrinhos (FIQ) e a Comic Con Experience (CCXP), bem como os eventos regionais de menor porte, como Festival Guia dos Quadrinhos e FestComix, em São Paulo, Santos 
Comic Expo, em Santos, Festival de Quadrinhos de Curitiba, entre outros, registram aumento de participação de artistas a cada ano, de acordo com a divulgação feita em seus sites e via matérias da imprensa especializada:

\begin{abstract}
A primeira Comic Con em São Paulo aconteceu em 2014 e atraiu 97 mil pessoas. No ano seguinte, o público cresceu $46 \%$ e ficou em 142 mil visitantes. Em 2016, um novo salto de 40\% levou público da conferência para 196 mil pessoas. Agora, a tendência é que o tamanho do público se estabilize: para este ano, a expectativa dos organizadores é atrair 220 mil pessoas. Tamanho público fez com que a Comic Com São Paulo superasse a convenção original, realizada em San Diego desde 1970. Neste ano, o evento por lá recebeu 130 mil pessoas. (EXAME, 2017º)
\end{abstract}

Já as plataformas como Social Comics $^{11}$ e Tapastic $^{12}$, oferecem uma grande variedade de histórias em quadrinhos, com a diferença de que a primeira é uma plataforma paga por assinatura mensal e que disponibiliza mais de 3.000 títulos independentes ou “mainstream", contando inclusive com publicações exclusivas, enquanto o Tapastic pode ser acessado de forma gratuita e oferece apenas trabalhos independentes.

A indústria cinematográfica segue a tendência observada nas feiras de quadrinhos em relação ao público: a quantidade de filmes adaptados a partir de histórias em quadrinhos que têm sido lançados nos cinemas também aumentou nos últimos anos. Mega produções, com orçamentos milionários, que nem sempre compartilham da mesma cronologia ou narrativa de suas histórias originárias, mas que levam fãs às salas e às compras de produtos relacionados aos quadrinhos, que vão desde canetas e camisetas à bonecos (action figures), vendidos em feiras e lojas especializadas (WRIGHT, 2008).

Embora Campos (2015) afirme que os primeiros produtos licenciados decorrentes de uma história em quadrinhos tenham sido relógios, brinquedos e bebidas do personagem Ally Sloper, de Marie Duval, ainda no século XIX, a prática de associar produções de entretenimento a produtos comercializáveis pode ser mais fortemente notada a partir do lançamento do filme de Star Wars, em 1977. Para Pegoraro (2016),

\footnotetext{
${ }^{10}$ ttps://exame.abril.com.br/negocios/os-numeros-impressionantes-da-comic-con-de-sp-a-maior-do-mundo/

${ }^{11} \mathrm{https}: / / \mathrm{www}$. socialcomics.com.br/

12 https://tapas.io/
} 
há uma retroalimentação entre filmes, produtos e fãs que torna os universos acessíveis e exploráveis. E há uma imersão dos fãs nos paratextos interativos que reforçam diversos temas na inteligência coletiva. No caso de "Star Wars", dos super-heróis Marvel e DC Comics, das histórias em quadrinhos e animações Disney, esse processo ocorre de forma contínua por décadas. A indústria do entretenimento descobriu esse filão e o usa como commodities de suas novas produções. Como normalmente ocorre no mercado, o efeito manada gera produções originais com paratextos superficiais e de péssima qualidade. É por essa razão que para cada um Harry Potter (produção literária original dos anos 1990 que se desenvolveu em filmes e demais produtos) temos dezenas de produções derivadas de textos e paratextos já conhecidos, testados e aprovados cujo hype pode ser trabalhado de modo mais controlado e cujas perspectivas de investimento e lucro podem ser mais facilmente calculadas. (PEGORARO, 2016, p.364)

O comportamento dos fãs de produtos de cultura pop em geral também é observado por Pustz (2000) quando afirma que, após a análise de diferentes comunidades de leitores de quadrinhos, há certas características compartilhadas pelos integrantes destes grupos e entre elas estão maior facilidade de inserção em mídias digitais, maior compreensão crítica de diversas linguagens, bem como uma escolarização acima da média, contrariando a visão de Theodore Adorno (MARTIN-BARBERO, 1997) de que os meios de comunicação de massa seriam responsáveis pelo empobrecimento do repertório de seus consumidores.

Então, a julgar pelas considerações de pesquisadores que se dedicam a estudar os fenômenos relacionados à cultura pop, entre eles os quadrinhos, existe um equívoco em se definir quadrinhos como uma forma de produção cultural inferior. Por isso, não só a internet, mas também as publicações acadêmicas e a própria indústria do entretenimento, podem contribuir para que a aceitação em relação aos quadrinhos, por parte de educadores, pais e público em geral, seja maior, propiciando assim, que sejam compreendidos como bens culturais que são. Para Vergueiro (2017), tanto autores como leitores, estão menos temerosos em relação ao futuro da Nona Arte e conseguem enxergar "o futuro como uma grande promessa, uma realidade na qual as histórias em quadrinhos encontrem seu papel como legítima produção artística devidamente reconhecida" (VERGUEIRO, 2017b, p.5). 


\subsection{As histórias em quadrinhos como bens culturais}

Ao afirmar que é possível considerar a organização social da cultura, "como um sistema de significações realizado, que está embutido em uma série completa de atividades, relações e instituições", Williams (2008, p.208) estabelece que há práticas que delimitam e legitimam a existência de determinadas culturas. Entre os diversos tipos de cultura que surgem a partir de práticas compartilhadas por certos grupos, podemos citar a existência de uma cultura das histórias em quadrinhos, corroborando o que Mathew Pustz (2000) atesta em sua pesquisa.

Para elucidar suas considerações sobre a formação das organizações culturais, Williams (2008, p. 68) detalha a história dos processos culturais dentro da perspectiva da Sociologia e define cada um dos elementos constitutivos do que ele considera um sistema das organizações envolvidas nesses processos. Para o autor, é possível classificar as formações modernas de acordo com alguns critérios que ele mesmo estabelece:

I. as que se baseiam em participação formal de associados, com modalidades variáveis de autoridade ou decisão interna, e de constituição de eleição;

II. as que não se baseiam na participação formal de associados, mas se organizam em torno de uma manifestação pública coletiva, tal qual uma exposição, um jornal ou um periódico do grupo, ou um manifesto explícito;

III. as que não se baseiam na participação formal de associados nem em qualquer manifestação pública coletiva continuada, mas nas quais existe associação consciente ou identificação grupal, manifestada de modo informal ou ocasional, ou por vezes, limitada ou trabalho em conjunto ou a relações de caráter mais geral.

Williams (2008, p.70) ainda classifica os tipos de relações externas que as formações podem estabelecer, dividindo-as em três grupos:

a) especializadas, como nos casos de apoio ou de promoção em determinado meio ou ramo de uma arte e, em certas circunstâncias, em determinado estilo;

b) alternativas, como nos casos de oferta de facilidades alternativas para a produção, exposição ou publicação de determinados tipos de obras, quando se acredita que as instituições existentes as excluem ou tendem a excluí-las; 
c) contestadoras, nas quais os casos representados (b) são alçados a contestação ativa às instituições estabelecidas ou, de maneira mais geral, às condições dentro das quais estas existem.

A categorização de Williams é significativa no sentido de fornecer algumas evidências sobre a importância dos espaços dedicados à difusão cultural, demonstrando, por meio de suas ações, qual seria o seu impacto nas comunidades onde estão inseridos, sugerindo exemplos de outras instituições com as mesmas características como uma forma de ilustrar que tanto as formações artísticas, como suas relações externas, são elementos inerentes à cultura

Assim, ainda que o conceito de gibiteca seja relativamente recente, as relações que ela estabelece quanto à difusão cultural podem ser observadas nas categorizações de Williams, ou seja, a Gibiteca de Santos poderia ser definida como uma associação do tipo II-a: Uma associação onde os indivíduos "se organizam em torno de uma manifestação pública coletiva, tal qual uma exposição, um jornal ou um periódico do grupo, ou um manifesto explícito" cujas relações externas são especializadas, ou seja, oferecem "apoio ou de promoção em determinado meio ou ramo de uma arte e, em certas circunstâncias, em determinado estilo". No entanto, esta interpretação é relativa, pois, dependendo dos objetivos de um evento ou de uma exposição, essa classificação poderia variar entre II-b e II-c, mas sempre atendendo à categorização citada.

Os exemplos definidos por Williams surgiram no final do século XIX em contextos onde a produção artística, muitas vezes restrita a espaços mais tradicionais, como museus e universidades, não representava a diversidade cultural que era produzida por artistas independentes de forma marginal. Por isso, as formações citadas se tornaram os meios pelo qual o público podia ter acesso a uma variedade de obras que não se encaixavam em um padrão hegemônico e elitista. Sendo assim: "É aprendendo a estudar a natureza e a diversidade das formações culturais, que podemos caminhar na direção de uma compreensão mais adequada dos processos culturais imediatos da produção cultural” (WILLIAMS, 2008, p.85).

Vergueiro (2005) também apresenta uma classificação para melhor compreensão da cultura dos quadrinhos, nesse caso, em relação aos tipos de leitores de acordo com seus padrões de consumo das revistas. No entanto, alerta que não é possível obter domínio suficiente sobre essas categorias, ainda que outros autores tenham se debruçado anteriormente em cima dessas questões. De qualquer forma, as classificações podem 
ilustrar que, tal qual ocorre com a cultura de maneira geral, os leitores de quadrinhos não correspondem a um bloco monolítico de pessoas, com hábitos similares. Assim, são eles:

a) eventuais: aqueles que usufruem das histórias em quadrinhos da mesma forma como utilizam todas as outras modalidades de leitura, sem qualquer predileção especial por esse meio de comunicação específico, com um conhecimento apenas superficial de autores ou títulos e tendendo a se concentrar naqueles de maior popularidade. Não buscam nada além da satisfação momentânea de suas necessidades de leitura de entretenimento, sendo guiados muito mais por motivos circunstanciais do que por qualquer ato consciente de escolha;

b) exaustivos: os que leem apenas histórias em quadrinhos, mas não fazem qualquer tipo de seleção, consumindo à exaustão tudo o que for produzido pelo meio. Em termos etários, tendem a se concentrar nas camadas mais jovens da população. É possível supor que o número desses leitores diminui em proporção com o seu envelhecimento: quanto mais velhos, menor é a probabilidade da leitura exclusiva de histórias em quadrinhos, já que surgem outros interesses a dividir sua atenção. No entanto, essa regra não é assim tão rígida. Algumas vezes, leitores exaustivos são também grandes colecionadores;

c) seletivos: leitores que têm predileção apenas por determinados gêneros, personagens ou autores. Leem tudo o que é publicado em sua área de interesse e buscam fazer a correlação de suas leituras com outros meios de comunicação de massa. Leitores seletivos também costumam, algumas vezes, ser colecionadores desses materiais;

d) fanáticos: como o próprio nome diz, levam sua predileção a extremos. Não apenas leem as histórias de seus personagens e títulos prediletos, como também procuram saber o máximo possível sobre eles, conhecendo minúcias de produção, características específicas de cada desenhista ou roteirista, evolução histórica do protagonista e coadjuvantes, etc. Constantemente, são também ávidos colecionadores de tudo que diga respeito a sua predileção, englobando publicações de todos os tipos que se relacionem com ele, bem como filmes e suas trilhas sonoras, autógrafos dos autores e desenhos originais dos artistas. Os fanáticos não falam de outro assunto que não aquele de sua predileção e tendem a defender seus pontos de vista com unhas e dentes, parecendo não entender muito bem porque 
estes não são compartilhados pelo restante da população. Quando encontram outros com preocupações semelhantes, costumam criar clubes ou associações;

e) estudiosos: nem sempre são leitores tão ávidos, mas resolveram se debruçar sobre as histórias em quadrinhos para estudar suas características e relações com outros meios de comunicação, com outros aspectos da vida social ou sob o ponto de vista de sua aplicação em determinadas ciências ou atividades. Muitas vezes, a predileção pelo estudo das histórias em quadrinhos ocorre em função de contingências acadêmicas específicas, como a elaboração de uma tese ou trabalho de conclusão de curso de graduação, deixando de existir tão logo elas terminem. Outras vezes, esse estudo inicial funciona como um despertar para esse tipo de publicação, persistindo na vida intelectual do indivíduo, que continua a ler e a estudar os quadrinhos durante muito tempo após o término da atividade acadêmica que originalmente o levou a eles. Ele passa a fazer parte, então, de grupos mais exigentes de leitores, que procuram por materiais de maior nível de qualidade, que tenham condições de lhes trazer benefícios intelectuais inquestionáveis.

Quanto aos quadrinhos como produtos culturais legítimos, Carvalho acredita que é possível identificar seu processo de valorização na medida que "instâncias que antes os desprezavam, passaram a reconhecer seu valor e importância no espectro cultural mundial" (CARVALHO, 2017, p. 3). Este reconhecimento se deu a partir de um longo processo, porém, três obras se destacam como alavancas responsáveis pelo atual status dos quadrinhos:

1986 foi o ano, como nenhum outro, que trouxe obras que marcariam e modificariam o que se compreendia por quadrinhos até então, com trabalhos mais politizados e recheados de crítica política e social. Dentre estas obras, está a "tríade de 1986: Batman: O cavaleiro das Trevas, de Frank Miller, Watchmen, de Alan Moore e David Gibbons, e Maus, de Art Spiegelman. (CARVALHO, 2017, p. 100)

Ainda de acordo com Carvalho, "foi graças ao reconhecimento de Maus e à invasão das graphic novels no mercado, que os quadrinhos perderam o estigma de entretenimento barato e sem valor cultural" (CARVALHO, 2017, p.21), favorecendo assim, a solidificação de um processo de aceitação de que "a história em quadrinho constitui um campo de 
produção cultural específico, que pouco tem a ver com o da literatura ou das artes plásticas, como comumente se disseminou" (CARVALHO, 2017, p. 21)

Para sua pesquisa sobre a existência de uma cultura específica das histórias em quadrinhos, Pustz (2000) se baseou em entrevistas com frequentadores de eventos de quadrinhos, como comic cons - feiras, congressos de fãs - e consumidores de uma loja de quadrinhos chamada Daydreams, na cidade de Iowa, Estados Unidos. A partir da bibliografia elencada na confecção de seu livro, Pustz demonstra que, a partir de certos elementos encontrados nas interações entre leitores de histórias em quadrinhos, é possível afirmar que leitores e fãs criaram uma cultura distinta e com sua própria linguagem, conhecimento e práticas (2000, p. ix), tal qual ocorre em qualquer outro universo que gire em torno de uma determinada forma de arte:

Um exemplo recente captura acuradamente a ideia que este grupo de pessoas constitui uma cultura única. Em Simpsons Comics \#39, Homer e o "cara da loja de quadrinhos", dono da loja de quadrinhos de Springfield, são levados a julgamento por possuírem e venderem quadrinhos obscenos. Atuando em seu favor e ao de Homer, o "cara da loja de quadrinhos" faz uma declaração tão repleta de referências sobre quadrinhos e filmes de ficção científica, que o júri fica tão confuso a ponto de solicitar que um grupo de fãs traduza. (PUSTZ, 2000, p. ix, tradução nossa ${ }^{13}$ )

No episódio citado por Pustz (2000), os tradutores são leitores de quadrinhos, assim como os dois acusados, no entanto, o júri não é. A questão apontada pelos personagens é que os integrantes do júri não seriam empáticos a eles por desconhecerem o que envolve ser um fã de quadrinhos. Assim, o juiz é convencido a preencher o júri com alguns fãs que acabam inocentando os réus da acusação de obscenidade, indicando que grupos de fãs de quadrinhos podem ser muito diferentes dos "cidadãos comuns".

Pustz (2000) ainda atenta para o fato que, mesmo dentro da cultura dos quadrinhos, há culturas distintas, dependendo do tipo de quadrinhos que os leitores consomem, identificando comportamentos também específicos entre os fãs de quadrinhos

\footnotetext{
${ }^{13}$ One recent example accurately captures the idea that this group of people constitutes a unique culture. In Simpsons Comics \#39, Homer and the Comic Book Guy, owner of Springfield's comic book shop, are put on a trial for possessing and selling obscene comic books. Action on behalf of himself and Homer, the Comic Book Guy's statement, filled with references to comics and Science fiction films, so confuses the jury that the court needs a group of fans to translate.
} 
"mainstream" e "alternativos" e demonstrando como as revistas em quadrinhos contribuem para a construção dessas culturas.

Muito embora a frequência às lojas que vendem quadrinhos e outros produtos colecionáveis seja o principal foco da análise de Pustz (2000) os motivos que levam os leitores a esses espaços podem ser comparados aos que levam os visitantes da Gibiteca de Santos ao local, a partir do que é observado nos depoimentos de alguns dos participantes dos eventos que responderam o questionário online (Apêndice A), como a possibilidade de estar em um ambiente onde outras pessoas compartilhem dos mesmos gostos que você ou a possibilidade de ter acesso a quadrinhos raros que não são facilmente encontrados em livrarias ou bancas de jornais.

Frequentadas basicamente por leitores de histórias em quadrinhos, as "comic shops" também serviriam de espaços culturais ou clubes onde "os fãs podem passar o tempo sendo eles mesmos entre amigos e indivíduos com a mesma mentalidade que a sua" (PUSTZ, 2000, p. x). Da mesma forma, as gibitecas possibilitam acesso a produtos que nem todos possuem poder aquisitivo para comprar, ou seja, assim como as lojas de quadrinhos são espaços para a cultura tanto quanto para o comércio, as gibitecas, ao eliminarem o fator econômico da equação e oferecerem espaços para socialização entre os leitores de quadrinhos, poderiam ser consideradas também como espaços culturais ou clubes.

A interação que ocorre por meio da socialização é uma prática que contribui para o consumo das revistas em quadrinhos: Ao criar um senso de cooperação entre leitores e criadores por meio das seções de cartas dos leitores em cada edição, editoras como a antiga EC Comics ofereciam aos consumidores a chance de interagir entre si e entre seus artistas favoritos (PUSTZ, 2000, p. xi), permitindo que os fãs sugerissem rumos e desfechos para as histórias que acompanhavam.

Hoje em dia, essa interação é feita por meio de sites e redes sociais, via comentários e discussões acaloradas sobre questões relacionadas ao mercado, personagens, artistas e o que mais surgir em torno das publicações mais populares. É também por meio das redes sociais e eventos presenciais realizados por sites especializados que fãs refletem acerca de temas relacionados aos quadrinhos, como ocorre nos eventos promovidos pela Gibiteca de Santos. 
Entre quadrinistas, editores de quadrinhos e jornalistas que contribuíram com depoimentos para o vídeo de aniversário de 25 anos da Gibiteca de $\operatorname{Santos}^{14}$, a afirmação de que as gibitecas contribuem para formação de leitores é recorrente, indicando a forte associação dos quadrinhos com a alfabetização no Brasil. Artistas também ressaltam sua importância para a divulgação dos quadrinhos independentes e para a formação de outros artistas que realizam os cursos oferecidos no local.

Além dos elementos mencionados, o colecionismo é mais uma característica presente na cultura das histórias em quadrinhos e é graças a essa prática que muitas gibitecas são mantidas ou iniciadas, como é o caso da Gibiteca de Santos, cujo acervo hoje depende exclusivamente da doação desses colecionadores.

Wright (2008) afirma que grande parte das práticas relacionadas ao ato de colecionar quadrinhos está ligada à sua materialidade: "qualquer pessoa que já tenha precisado mudar uma coleção de gibis de endereço pode testemunhar sobre sua presença física, principalmente no que tange ao seu peso" (2008, tradução nossa $\left.{ }^{15}\right)$. Como lembra o autor, uma edição de The Flash não pesa muito, mas vários volumes colecionados ao longo de anos, enchem certamente uma caixa.

Assim, a prática social de colecionar afeta os envolvidos de forma física, pois envolve a classificação, separação, conservação, tudo de acordo com os fins que cada revista pode ter, não sendo possível então, separar tal atividade da materialidade de seus objetos. Por isso, é compreensível que muitos dos colecionadores entrevistados por Wright, afirmem que manter quadrinhos em arquivos de computador ou outros dispositivos eletrônicos não caracterizaria uma coleção, pois, afinal, o prazer da experiência envolve atividades como "caçar" quadrinhos raros, organizá-los, observar suas condições e texturas...

Apesar de algumas distinções entre as práticas dos colecionadores americanos mencionados por Pustz (2000) e os santistas, a cultura das histórias em quadrinhos é unificada pelo hábito da leitura de seus produtos. "Leitores "mainstream" e "alternativos" são todos devotados à mídia dos quadrinhos e são unidos por seu conhecimento e

\footnotetext{
${ }^{14} \mathrm{https}: / /$ www.youtube.com/watch?v=8I9y_1zD_1k

15 [...] ]anyone else who has ever moved a comic book collection, especially a sizable one, can testify to its material presence, particularly its weight
} 
especialização em literacia dos quadrinhos" (PUSTZ, 2000, p. xii, tradução nossa ${ }^{16}$ ), o que significa, em um nível mais básico, que essa literacia envolve fluência na linguagem dos quadrinhos. Pustz (2000, p. xii) explica que essa linguagem é internalizada pelos leitores com base em sua experiência com os quadrinhos e é por meio dessa compreensão que o público é delimitado, uma vez que as publicações costumam ser direcionadas a leitores que possuem um conhecimento prévio necessário para a decodificação das mensagens transmitidas nas histórias.

Tal qual ocorre com outras expressões artísticas ou mesmo em relação aos esportes, “fãs de quadrinhos apreciam ser especialistas, mesmo quando não há ninguém com quem compartilhar seu conhecimento" (PUSTZ, 2000, p. 114, tradução nossa ${ }^{17}$ ). Nesse sentido, Pustz afirma que

os fãs de gibis possuem um conhecimento muito mais detalhado sobre os títulos que escolhem, até mesmo quando se trata de alguma história que não tenham lido, do que os não-leitores podem imaginar. Como resultado, o leitor ideal que essas histórias embebidas de literacia "quadrinística" miram não é um indivíduo: é a própria cultura das histórias em quadrinhos. (PUSTZ, 2000, p.114, tradução nossa ${ }^{18}$ )

Ao citar Umberto Eco, Carvalho (2017) defende que, para entendermos a importância da cultura de massa, onde os quadrinhos estariam inseridos como produtos, é preciso ter em mente que ela oferece uma quantidade significativa de informações a serem consumidas e que não dependem de critérios de discriminação, favorecendo que o homem se sensibilize em relação ao universo do qual faz parte (CARVALHO, 2017, p. 58).

Quanto à definição das histórias em quadrinhos como um campo de produção cultural distinto, vale ressaltar que elas resistiram a modismos e preconceitos e se consolidaram como "uma forma de narrativa que engloba pluralidades estilísticas e ideológicas, mesmo sendo pautada pela lógica consumista do mercado editorial

\footnotetext{
${ }^{16}$ Mainstream and alternative readers are all devoted to the comics medium and are united by their knowledge and expertise in comics literacy.

${ }^{17}[\ldots]$ comics fans enjoy being experts, even when there is no one with whom to share their knowledge.

${ }^{18}$ [...] comic book fans have more detailed knowledge of their texts of choice - even of stories they have never read - than most people in the outside world can imagine. As a result, the ideal reader at which these stories steeped in comics literacy are aimed is not an individual: it is comic book culture itself.
} 
(CARVALHO, 2017, p. 73), constituindo assim, um campo produtivo com moldes específicos em constante processo de renovação.

Nesse sentido, ao estipular que as histórias em quadrinhos constituem um campo de produção cultural específico, com suas próprias peculiaridades, Carvalho (2017) explica que, como outros campos das artes, assim com a literatura e o cinema, os quadrinhos contemplam gêneros narrativos que podem ser veiculados por meio de diferentes suportes, como as graphic novels:

O fato de mais de uma obra ser designada como tal (graphic novel) não faz de todas as outras obras que recebem essa denominação como pertencentes ao mesmo gênero. Seria o mesmo que dizer que uma revista em quadrinhos de super-heróis e outra de terror fazem parte do gênero "revista em quadrinhos" simplesmente por terem sido publicadas por meio do mesmo suporte editorial. (CARVALHO, 2017, p. 123)

Assim, como outros autores já afirmaram anteriormente (GROESTEEN, 2015; BARBIERI, 2017, MCCLOUD, 1993), as histórias em quadrinhos possuem recursos narrativos específicos que exigem de seus fãs e consumidores habilidades também específicas para decodificá-los:

Sem o domínio dessa linguagem, um domínio que muitos fãs internalizaram, quadrinhos se provaram uma leitura difícil para aqueles sem experiência. McCloud diz que cada aspecto de uma página de quadrinhos, do layout do painel ao uso das cores, da interação entre palavras e imagens à tendência do artista em direção (ou afastamento) do abstrato, é importante para a criação de significado. (PUSTZ, 2000, 115, tradução nossa ${ }^{19}$ )

A compreensão do que Groesteen (2015) afirma sobre a solidariedade icônica das imagens, indica que os leitores irão apreciar uma história em níveis diferentes de interpretação, dependendo de sua capacidade de decodificar e desvendar as camadas de significados e referências contidas nelas. Dessa forma, a construção de significados a partir de uma narrativa de quadrinhos só é possível se o leitor estiver em posse das ferramentas necessárias para essa função.

\footnotetext{
${ }^{19}$ Without expertise in this language, an expertise that many fans have internalized, comic books can prove to be difficult Reading for the uninitiated. McCloud argues that every aspect $f$ a comics page, from the panel layout to the use of color, from the interaction of words and pictures to the artist's tendency toward (or away from) the abstract, is important in creating meaning.
} 
Prova da necessidade de ações voltadas para o desenvolvimento dessas habilidades é a atuação da organização The Ink $\operatorname{Link}^{20}$ : formada por pesquisadores de diversas áreas do conhecimento, a $\mathrm{ONG}$ atua em vários países do mundo levando informações sobre ciências, ecologia, preservação ambiental e saúde por meio de histórias em quadrinhos. No entanto, a confecção das histórias se pauta nos resultados obtidos a partir de um jogo desenvolvido especialmente para identificar o conhecimento de ícones e recursos gráficos pertinentes às histórias em quadrinhos de cada público alvo das campanhas.

Por exemplo, ao criar uma campanha de vacinação usando histórias em quadrinhos na América Central, os cientistas responsáveis imaginaram que o uso de personagens que remetessem aos super-heróis seria uma maneira de chamar a atenção da população para a importância da vacinação. No entanto, o que os pesquisadores do The Ink Link constataram foi que o repertório iconográfico da população alvo da campanha de vacinação não continha referências sobre super-heróis e isso gerou baixa adesão das pessoas à campanha. Para reverter a situação, os cientistas desenvolveram então uma história em quadrinhos com o auxílio de uma desenhista local e participaram de vivências nas comunidades, o que gerou uma narrativa colaborativa completamente diferente da inicial, resultando em uma ação com maior adesão da população, ou seja, a narrativa criada continha elementos iconográficos que dialogavam com o repertório de seus leitores ${ }^{21}$.

Os elementos iconográficos dos quadrinhos compõem o que Pustz (2000, p. 115) chama de "gramática visual dos quadrinhos". De acordo com ele, as histórias em quadrinhos demandam uma série de habilidades de leitura bem específicas, das quais muitos americanos não dispõem:

Fisicamente, o ato de ler uma história em quadrinhos é diferente da leitura de um livro tradicional. $\mathrm{O}$ olho não pode simplesmente ir da esquerda para a direita da mesma forma linear em que lê apenas as palavras. Lawrence Abbott sugere que, com quadrinhos, o movimento dos olhos em um painel é determinado por convenções de leitura tanto da esquerdapara-a-direita, do topo-para-a-base, tanto quanto por padrões mais livres

\footnotetext{
${ }^{20} \mathrm{http}: / /$ www.theinklink.org/fr

${ }^{21}$ Encontro realizado por Skype com Laure Garancher, uma das pesquisadoras do grupo The Ink Link no III Entre Aspas, realizado em Leopoldina, MG, em maio de 2017. Fonte: http://historiadoensino.blogspot.com/2017/03/laure-garancher-no-iii-entre-aspas.html
} 
associados à contemplação das imagens. (PUSTZ, 2000 p. 122, tradução nossa $\mathrm{s}^{22}$ )

Logo, como a leitura de uma história em quadrinhos exige obrigatoriamente habilidades distintas, isso significa que sua literacia não é compartilhada por todos os tipos de leitores: "Essa literacia funciona, então, como uma das fronteiras principais entre os leitores e não-leitores de quadrinhos" (PUSTZ, 2000, p.123, tradução nossa ${ }^{23}$ ). Ainda nas palavras de Pustz "a linguagem dos quadrinhos ajuda a unificar a cultura dos quadrinhos tanto quanto qualquer linguagem comum ajuda a unificar qualquer grupo de pessoas" (2000, p. 124, tradução nossa $\left.{ }^{24}\right)$.

A importância de se estabelecer essa distinção reside no fato de que, sem ela, o reconhecimento das histórias em quadrinhos como produtos culturais legítimos e de valor equivalente a qualquer outra manifestação artística, não é possível. Por muito tempo, a validação das histórias em quadrinhos se deu por meio da comparação entre uma história e alguma outra produção como cinema ou literatura.

Seria possível atribuir, ao não reconhecimento dos quadrinhos como uma forma de expressão artística e cultural de igual valor e importância que qualquer outra manifestação, o descaso e falta de interesse dos órgãos públicos em relação às gibitecas, uma vez que diversas cidades e espaços culturais contam com eventos distintos para a realização de feiras literárias ou de cinema, por exemplo.

No entanto, Vergueiro (2017) acredita que há motivos para ser otimista quanto à mudança dessa mentalidade, pois o Brasil tem acompanhado as tendências internacionais de produção acadêmica sobre quadrinhos, representando "uma nova etapa do processo de legitimação cultural do meio, que passa a ser visto de forma mais positiva por parte de parcelas significativas e influentes da sociedade" (2017, p.166).

\footnotetext{
${ }^{22}$ Physically, the act of Reading a comic book is unlike Reading a traditional book. The eye cannot simply go from left to right in the same linear way it can when Reading words only. Lawrence Abbot suggests that, with comics, "eye movement in a pane lies determined by both left-to-right, top-to-bottom conventions of Reading and by the freer patterns associated with the contemplation of pictures".

${ }^{23}$ This literacy thus functions as one of the primary boundaries between comic book readers and nonreaders.

${ }^{24}$ The language of comics helps to unify comic book culture, just as any common language helps to unify any group of people.
} 
Essas tendências, associadas às práticas que são desenvolvidas na Gibiteca Henfil, no Centro Cultural São Paulo, bem como os resultados obtidos pela Gibiteca de Santos, podem ilustrar a afirmação de que a mentalidade acerca da importância das histórias em quadrinhos, e, consequentemente, de espaços onde possam ser apreciadas, está de fato passando por mudanças, justificando então, a necessidade da existência de gibitecas em todo o país. 


\section{AS GIBITECAS}

\subsection{O surgimento das gibitecas}

Embora o termo gibiteca tenha sido adotado a partir da junção do nome mais popular que as revistas em quadrinhos recebem no Brasil e a palavra biblioteca (gibi + biblioteca $=$ gibiteca), Waldomiro Vergueiro considera interessante salientar que os primeiros espaços do gênero não tinham relação com bibliotecas, mas com associações de fãs e leitores de quadrinhos que não eram profissionais da área de biblioteconomia (VERGUEIRO, 1994, p. 16). Entre os objetivos desses colecionadores em criar as gibitecas estavam o interesse em oferecer ao público acesso às suas revistas favoritas, preservá-las para as futuras gerações, promover a disseminação do hábito de ler quadrinhos entre a população e incentivar novos artistas. Ainda de acordo com Vergueiro,

bibliotecas públicas especialmente dedicadas à coleta, armazenamento e disseminação de histórias em quadrinhos são instituições genuinamente brasileiras, existindo desde o início da década de 1980, quando uma instituição pública na capital do Estado do Paraná decidiu fundar a primeira unidade desse tipo, que batizou com o nome de gibiteca, um neologismo que mescla a forma como as revistas de histórias em quadrinhos são tradicional e carinhosamente referidas no país - gibis -, com as unidades de informação - bibliotecas. Com o surgimento da Gibiteca de Curitiba, cunhava-se o termo genérico para denominar qualquer biblioteca que colocasse as histórias em quadrinhos como o centro de sua prática de serviço de informação e que seria então utilizado em todo o país. (VERGUEIRO, 2005, p. 4)

A oposição da sociedade talvez não seja o fator determinante para explicar a inexistência ou escassez das histórias em quadrinhos no acervo das bibliotecas. De acordo com Vergueiro (2005), muitos responsáveis por espaços dedicados à leitura não se interessam em selecionar os quadrinhos para suas bibliotecas por entenderem que eles não se adequavam aos critérios de qualidade que haviam definido para seus acervos. No entanto, este fator não está relacionado somente à falta de interesse de bibliotecários, mas ao fato de que a prática bibliotecária envolve um emaranhado das relações sociais que caracterizam um determinado grupo de pessoas e aqueles que atuam em serviços de informação são tão influenciados pelas ideias dominantes na sociedade quanto as pessoas 
a que servem. Por isso, é possível dizer que a resistência dos bibliotecários às histórias em quadrinhos seja um reflexo da resistência da própria sociedade em relação aos quadrinhos e que vem diminuindo à medida que todos os meios de comunicação de massa passaram a ser vistos com outros olhos (VERGUEIRO, 2005, p. 4).

Para Scott (1991), mesmo que uma gibiteca disponha de quadrinhos demasiadamente antigos, o bibliotecário responsável deveria saber responder honestamente às perguntas mais contumazes dos visitantes, como por exemplo: "Qual é seu quadrinho mais antigo?", "Qual é o item mais valioso?" e, no caso de haver entre seus itens, alguma raridade, também deveria ser capaz de explicar que, a menos que o visitante tenha uma razão muito importante para manuseá-lo, seria melhor evitar o desgaste da obra sem necessidade (SCOTT, 1991, p.44). Assim,

políticas precisam ser estabelecidas para permitir que pesquisadores tirem melhor proveito de uma coleção. Normalmente, como quadrinhos são meios de massa, o pesquisador irá precisar comparar, contrastar, ou mesmo ler uma grande quantidade de quadrinhos. O leitor recreacional, por outro lado, irá querer ler Fabulosos X-Men desde o começo e terminar de forma ininterrupta, o que pode levar em média três semanas. Ambos usuários irão requerer dedicação de tempo dos funcionários para lhes entregar uma grande quantidade de quadrinhos, supervisionar seu uso e devolvê-los às prateleiras. (SCOTT, 1991, p. 45, tradução nossa ${ }^{25}$ )

Além da escassez mencionada, o descaso em relação às gibitecas é destacado na imprensa $^{26}$ e confirmado por leitores de quadrinhos de cidades como Belém e Fortaleza, além de também aparecer em grupos de discussão sobre quadrinhos no Facebook. Em uma das matérias, a jornalista afirma que o acervo atual da Gibiteca de Fortaleza é de 6.000 quadrinhos ${ }^{27}$. "Cerca de 2.600 a mais que o acervo inicial. O aumento não é devido a novas compras, mas sim a doações. O número, contudo, deveria ser maior se não fossem os furtos”. E a Gibiteca de Belem - Centur ${ }^{28}$, não recebe a devida atenção da Secretaria de Cultura do Estado do Pará, sendo também, alvo de furtos e roubos constantes.

\footnotetext{
${ }^{25}$ Policies need to be established that will allow the researcher to use the collection to best advantage. Typically, since comics are a mass medium, the researcher will need to compare, contrast, or even read large numbers of comic books. The recreational reader, on the other hand, will sometimes want to read The Uncanny X-Men from start to finish uninterrupted, which can easily take three weeks. Both users will require big investments of staff time in retrieving large numbers of comic books, supervising their use, and reshelving them.

${ }^{26}$ https://jbomdia.com.br/noticias/crise-na-cultura-biblioteca-tem-energia-cortada-por-falta-de-pagamento

${ }^{27} \mathrm{http}: / /$ revistazinext.blogspot.com.br/2011/06/o-povo-online-vida-e-arte-cade-o-gibi.html

${ }^{28} \mathrm{http}$ ://www.fcp.pa.gov.br/espacos-culturais/sede/biblioteca-arthur-vianna/gibiteca
} 
Ainda assim, o Brasil presenciou a criação de espaços para a leitura de revistas em quadrinhos que pode ser relacionada à abertura política do país nos anos 1980, quando o fim da ditadura propiciou que iniciativas públicas na área de leitura fossem tomadas. Como explica Bari,

em 1982, um grupo de desenhistas e amantes das histórias em quadrinhos se organizou e inaugurou, na cidade de Curitiba, capital do estado do Paraná, a Gibiteca de Curitiba, primeiro acervo público do gênero no país, com estrutura para consultas, empréstimos, exposições e eventos. (BARI, 2008, p.52)

A existência de um local físico para encontro de fãs, sejam eles convenções ou gibitecas, possibilita que os leitores interajam e conversem sobre seus personagens favoritos e discutam questões relacionadas aos quadrinhos (PUSTZ, 2000, p. xiii), contribuindo para a formação de uma cultura específica das histórias em quadrinhos. Pustz atribui à interação um papel crucial para a importância dessa cultura, uma vez que a participação em eventos é central para sua realização, pois cada membro da cultura dos quadrinhos é um participante ativo dela, não apenas um consumidor. Portanto, "essa cultura serve como um exemplo importante de como a cultura em geral é criada por meio da participação e delimitação de fronteiras" (PUSTZ, 2000, p. xiv, tradução nossa ${ }^{29}$ ). Entre as gibitecas que promovem eventos para a interação de seus frequentadores, as gibitecas de Curitiba e a Henfil se destacam com uma programação ativa desde sua criação.

\subsection{As gibitecas públicas}

Embora o país tenha passado por grandes mudanças a partir do fim da ditadura, Sonia Bibe Luyten já havia fundado a primeira mangateca do Brasil em 1972, no prédio da Escola de Comunicações e Artes da Universidade de São Paulo. De acordo com Luyten, o acervo criado para pesquisa propiciou também o nascimento de uma associação de leitores de mangás (LUYTEN, 2003, p. 10).

$29[\ldots]$ this culture can serve as na importante exemple of how culture in general is created through participation and boundaries. 
Porém, a primeira gibiteca a integrar um sistema de bibliotecas públicas foi a Gibiteca Henfil, em 1991, como esclarece Vergueiro:

A primeira gibiteca brasileira a surgir dentro de um serviço de biblioteca pública, a partir de iniciativa da própria administração municipal, foi a Gibiteca Henfil, órgão do Departamento de Bibliotecas Infanto-Juvenis da Secretaria de Cultura do município de São Paulo, inaugurada em 1991 e hoje possuindo o maior acervo do país, com mais de 100 mil exemplares. Além de possuir um vasto acervo e ser responsável por um dos maiores índices de freqüência das bibliotecas públicas da cidade de São Paulo, a Gibiteca Henfil também se coloca como um grande centro de eventos relacionados com os quadrinhos, promovendo cursos, exposições, palestras, debates e lançamentos de novas obras e servindo como ponto de encontro para reuniões de leitores e de associações de quadrinhistas. (VERGUEIRO, 2005, p. 5)

A relevância da Gibiteca Henfil não se dá apenas em função do número de frequentadores, mas também pelo número de empréstimos e exemplares, que aumentou significativamente em pouco tempo de existência, gerando a necessidade de mudança de endereço e nome para melhor abrigar sua coleção.

Primeira gibiteca com sistema de consulta e empréstimo do Brasil, estava inicialmente localizada no bairro da Vila Mariana, em São Paulo, como um anexo da Biblioteca Infanto-Juvenil Viriato Correa. Sua fundação ocorreu nos anos 1990 devido à necessidade de aumentar o acervo das bibliotecas municipais que estava defasado. Assim, foram destinados 5 milhões de dólares pela Secretaria Municipal de Cultura para a atualização dos acervos e, entre as publicações adquiridas, estavam os quadrinhos para as bibliotecas infanto-juvenis (ABUD; PINHO, 2011).

Para a aquisição e seleção das obras que seriam destinadas à formação dos acervos das gibitecas, uma comissão de especialistas foi constituída para que os títulos pudessem compor coleções variadas e que atendesse públicos diversos: 
Esta comissão foi oficializada através da Portaria n.1.074/90 e publicada no Diário Oficial do Município (D.O.M.) em 25/10/1990, página 10. Foi composta por seis funcionários da SMC, são eles: Maria Luiza Barros Gomes de Matos (Chefe da BIJ Viriato Correa), Silvana Mattiazzo Casella (Bibliotecária BIJ Planejamento), Irma Cleide Grillo (Bibliotecária da BIJ Viriato Correa), Guaraciaba Aparecida de Almeida Rodrigues (Bibliotecária BP Planejamento), Laurivaldo Klink Júnior (Bibliotecário do Centro Cultural São Paulo), Og Gil Gregório da Silva (Assistente Técnico da BIJ Viriato Correa), Odete Piccolo (Bibliotecária da BIJ Viriato Correa), Dario Chaves (Oficial de Administração Geral). Havia também dois especialistas na área de histórias em quadrinhos, e ambos professores da ECA/USP, o professor e jornalista Álvaro de Moya (autor do projeto "Gibizada") e Waldomiro de Castro Santos Vergueiro.

Esta comissão tinha as seguintes atribuições: planejar e executar a implantação da Gibiteca; proceder estudos de adequação de espaço e de viabilização de infra-estrutura; elaborar a programação de eventos e atividades; estabelecer a administração e funcionamento da Gibiteca; e por último a avaliação do desenvolvimento dos trabalhos. (ABUD; PINHO, 2011, p. 4)

O principal objetivo da criação da Gibiteca Henfil era a preservação e difusão das histórias em quadrinhos: "O conceito de preservação não se limita somente ao escrito ou a arte. Preservar está atrelado ao que é um bem patrimonial para a sociedade ou aquilo que é reflexo da memória e da identidade de uma comunidade" (ABUD; PINHO, 2011, p. 2), ou seja, havia a necessidade de se tomar medidas para resguardar em locais públicos a produção cultural e técnica relacionadas aos quadrinhos. Assim,

a Gibiteca tinha por propósito servir à pesquisa, à formação, preservação e atualização do acervo, à coleta de documentação para formação de base de dados, e servir como disseminador da informação sobre quadrinhos, bem como desenvolver um acervo especializado. Para o cumprimento das regras da biblioteconomia, obrigatoriamente deveria coletar, selecionar, processar tecnicamente e armazenar de modo adequado todo este acervo. (ABUD; PINHO, 2011, p.5)

Os 3.000 títulos na época de sua inauguração passaram para 75.000 exemplares em 1998 e havia 12.000 leitores cadastrados que usufruíam do espaço, o que gerou a necessidade de mudança para um lugar maior. Por isso, em “outubro de 1999 a Gibiteca foi reinaugurada, em um novo espaço na qualidade de seção técnica da Divisão de Bibliotecas do CCSP (Centro Cultural São Paulo), dividindo seu espaço com a Biblioteca Braille" (Figura 2) (ABUD; PINHO, 2011, p. 7). 
Figura 2 - Gibiteca Henfil

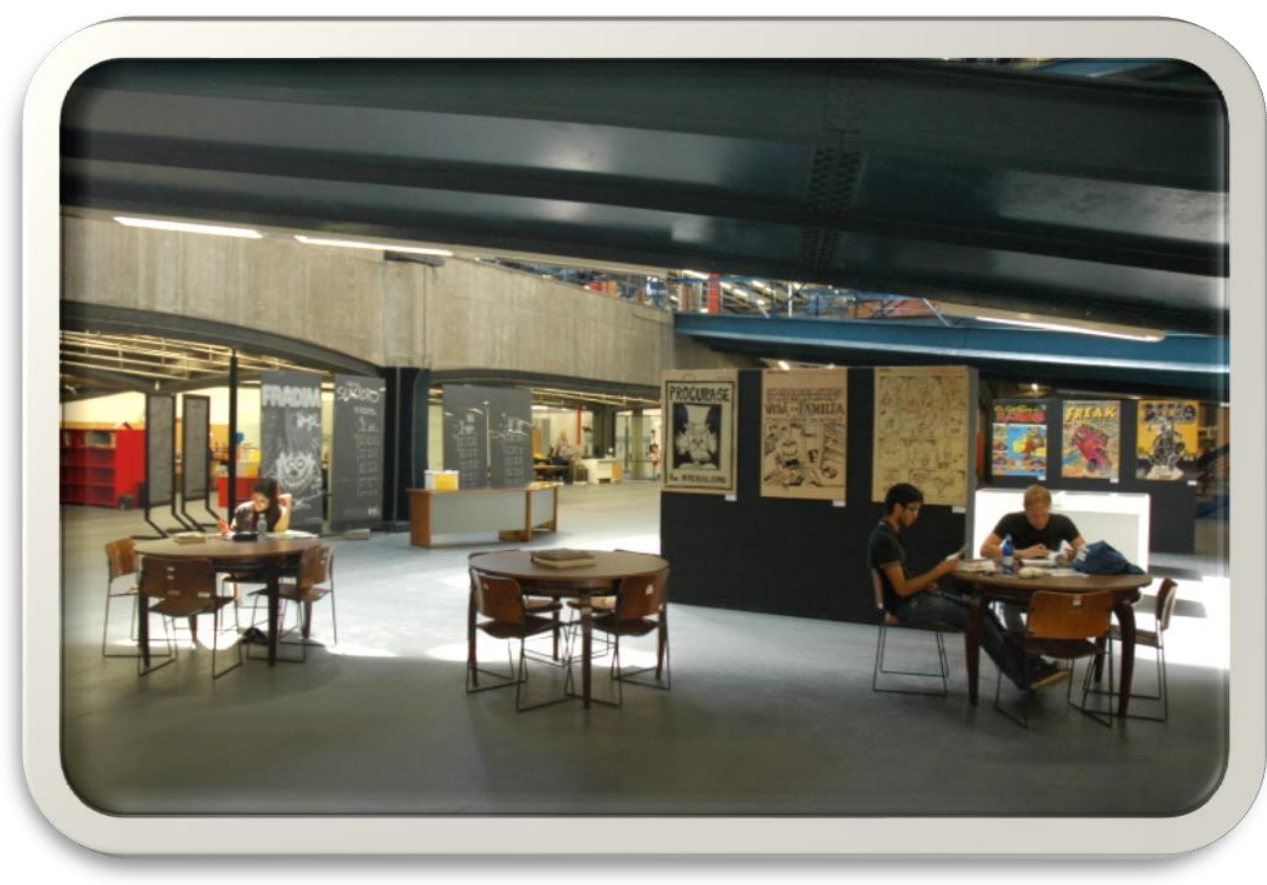

Fonte: Site do Centro Cultural São Paulo

Em 2004, o então diretor do CCSP, Carlos Augusto Calil, propôs a criação de um conselho consultivo da Gibiteca Henfil, com o objetivo de aprofundar a discussão sobre a programação e sobre a natureza cultural e política do acervo. $\mathrm{O}$ conselho ficou ativo entre os anos de 2004 e 2007 e contava com a participação de especialistas em histórias em quadrinhos provenientes de diversas áreas do conhecimento, entre eles estavam pioneiros dos estudos das histórias em quadrinhos como Sonia Luyten e Waldomiro Vergueiro, além de José Alberto Lovreto, Cartunista e Presidente da Associação de Cartunistas do Estado de São Paulo e João Gualberto Costa, arquiteto, especialista em quadrinhos e diretor do Instituto Memorial de Artes Gráficas do Brasil (ABUD; PINHO, 2011, p. 7)

Em 1991, com o lançamento da primeira edição da obra Transubstanciação, do quadrinista Lourenço Mutarelli, o mercado de quadrinhos underground ganhou mais visibilidade, quando Mutarelli ganhou então o Grande Prêmio da I Bienal Internacional de Quadrinhos do Rio de Janeiro (BARI, 2008, p. 57). Com o êxito editorial que os quadrinhos vivenciavam, surgiram outras gibitecas. Assim, 
o aparecimento de gibitecas devidamente departamentalizadas nas redes de bibliotecas públicas do Brasil ocorreu apenas na década de 1990, o que finalmente concretizou os conceitos teóricos relativos aos benefícios dessa forma de estrutura para a leitura pública, aprimoramento a gestão informacional desses acervos. Por meio dessa mudança, temos para o início do séc. XXI a formação de um cenário de leitura pública mais democrático e propício à inserção das histórias em quadrinhos nos gostos de leitura de lazer da população. (BARI, 2008, p. 176)

Em 1992 são fundadas mais duas gibitecas públicas no Brasil: a Antônio Gobbo, em Belo Horizonte e a Gibiteca Marcel Rodrigues Paes, em Santos, São Paulo. A Gibiteca Antônio Gobbo leva esse nome em homenagem ao colecionador que doou seu acervo, com muitas obras de difícil aquisição nos dias de hoje, à Biblioteca Nacional de Histórias em Quadrinhos, nome que ele mesmo cunhou quando abriu seu acervo para o público em sua casa e que hoje se encontra hoje no prédio que abriga a Biblioteca Pública Infantil e Juvenil de Belo Horizonte, com cerca de 20.000 títulos que podem ser emprestados. O local também costuma receber exposições e encontros que buscam divulgar os artistas brasileiros independentes de quadrinhos, bem como aproximar comunidade dos quadrinhos, por meio de ações conjuntas com artistas locais e escolas públicas, como informado por um dos organizadores desses eventos, Afonso Andrade um dos responsáveis pelo local -, em visita realizada em julho de 2016.

Já a Gibiteca Municipal de Santos, localizada na orla da praia, recebeu o nome de Marcel Rodrigues Paes em homenagem ao colunista de quadrinhos do jornal local, $A$ Tribuna de Santos, com a doação de sua coleção após sua morte precoce. Hoje, conta com cerca de 30.000 títulos que são doados por moradores da cidade ou mesmo enviados de outras cidades, como uma coleção de quadrinhos portugueses enviada pela bedeteca de Amadora, em Portugal.

A Gibiteca Municipal de Santos também realiza eventos com frequência em seu espaço, no intuito de divulgar os artistas nacionais de quadrinhos, por meio de bate-papos ou exposições, o que lhe rendeu em 2016 o prêmio Jayme Cortez de incentivo ao quadrinho nacional no troféu Angelo Agostini ${ }^{30}$. Nesses mesmos moldes, a gibiteca Jorge Braga $^{31}$, em Goiânia, vem realizando eventos há 24 anos, sempre de forma gratuita.

\footnotetext{
${ }^{30} \mathrm{http}: / /$ aqcsp.blogspot.com.br/2016/01/32-premio-angelo-agostini-acontecera-no.html

${ }^{31}$ https://folhadegoianira.com.br/gibiteca-jorge-braga-comemora-24-anos-nesta-sexta-feira-2/
} 
Em artigo escrito para o periódico New Library World, em 1994, Waldomiro Vergueiro detalha a realidade das gibitecas brasileiras na época. De acordo com ele, alguns fatores contribuíram para que bibliotecários começassem a mudar sua percepção acerca das histórias em quadrinhos a ponto de incluírem os quadrinhos em suas coleções. Entre os fatores citados estão as pesquisas de autores proeminentes como Umberto Eco, Pierre Fresnault-Deruelle e Romam Bubern, que rebateram as acusações negativas contra os quadrinhos, mostrando que se tratavam apenas de preconceitos contra um meio de massa legítimo; o uso dos quadrinhos como uma ferramenta pedagógica como tema de estudo em escolas, que demonstrou a viabilidade dos quadrinhos em transmitir valores sociais; o aumento na produção de títulos chamados "graphic novels", apontando para a existência de um público com gosto mais refinado, conferindo aos quadrinhos um padrão de qualidade mais elevado; e a demanda, por parte dos consumidores, tanto crianças como adultos, que procuravam histórias em quadrinhos nas bibliotecas públicas.

Ainda de acordo com Vergueiro (1994, p. 15), uma pesquisa feita em 132 bibliotecas públicas do país, demonstrou que 57 delas já incluíam histórias em quadrinhos em suas coleções. Mesmo entre as que as possuíam, apenas 5 delas não manifestaram interesse em adquiri-las.

Scott (1991, p. 23) defende que as habilidades de especialistas são requisitadas quando se trata de coleção de quadrinhos porque as revistas adquiridas por uma biblioteca são, majoritariamente, frutos de doações e são de difícil aquisição contínua, principalmente quando se trata de um espaço público, onde licitações costumam conferir uma morosidade ao processo que impossibilitaria o acesso aos títulos seriados, pois estes saem de circulação rapidamente após sua publicação.

Essas habilidades também precisariam levar em conta a fragilidade do material com o qual as revistas são publicadas e sua frequência, que faz com que certos títulos se tornem raros: como no caso de qualquer outra mídia, alguma mediação entre o leitor e a coleção se faz necessária (SCOTT.1991, p. 23).

O fato de os quadrinhos serem diferentes de todos os outros materiais normalmente encontrados em uma biblioteca, faz com que seja necessária a ajuda de um especialista em cada parte do processo que envolve uma coleção de revistas ou tiras cômicas. Para Scott, como qualquer outro bibliotecário, alguém que lide com os quadrinhos deverá ser versado 
em catalogação, referência, preservação, levantamento de fundos e publicidade (SCOTT, 1991, p. 24).

No entanto, aumento no número de espaços dedicados à leitura de histórias em quadrinhos, a partir dos anos 1980, acabou gerando algumas dificuldades para os bibliotecários, pois grande parte deles não está habituada à mídia dos quadrinhos, não sabe que tipo de tratamento dispensar a eles (VERGUEIRO, 1994, p.16). O próprio nome gibiteca, de acordo com Vergueiro, não seria muito apropriado, uma vez que pode gerar confusão sobre as coleções por abranger apenas um tipo de publicação entre os tantos tipos existentes de histórias em quadrinhos e suportes.

Outra característica importante em relação às gibitecas brasileiras, é que existe uma pré-disposição de colecionadores em doar suas revistas aos espaços públicos (VERGUEIRO, 1994, p. 17), pois acreditam que seu material receberá bons cuidados dos bibliotecários. Entretanto, as doações formariam coleções mortas se não estiverem completas, pois, ao menos no que tange à pesquisa acadêmica, não poderiam servir de fonte para os estudiosos interessados (SCOTT, 1991, p. 28).

De qualquer forma, Vergueiro (1994) enfatiza que isso não deveria impedir os profissionais que lidam com as revistas de definir políticas de desenvolvimento e conservação das coleções. De acordo com o autor, é justamente a ausência dessas políticas que poderia acarretar que as gibitecas recebam centenas de quadrinhos "inúteis". Logo, instruções para a conservação das revistas serviriam tanto como um guia para os bibliotecários, como uma garantia para os leitores de que a biblioteca se compromete com a manutenção das publicações, conferindo credibilidade ao espaço.

\subsection{Manutenção, catalogação e programação de eventos das gibitecas}

Além de Scott (1991), que sugere de forma detalhada a melhor forma de se catalogar e manter uma coleção de histórias em quadrinhos, outros bibliotecários têm oferecido indicações para indexar as coleções de uma gibiteca. Para Severo (2012), os procedimentos para indexação de histórias em quadrinhos podem variar de acordo com os objetivos, público e material disponível por cada gibiteca. Ainda assim, considerando 
a falta de funcionários especializados, são estes materiais que deverão servir de suporte para as práticas dos bibliotecários responsáveis por coleções de quadrinhos.

Embora os avanços tecnológicos tenham propiciado o surgimento das histórias em quadrinhos digitais, o foco de espaços como a Gibiteca de Santos são as publicações impressas. Dessa forma, tais instituições poderiam se beneficiar do padrão apresentado por Severo (2012, p.61) cuja catalogação tem base na descrição de elementos básicos de indexação.

Além das gibitecas mencionadas, outras iniciativas têm surgido, como a Gibiteca de Barueri, Gibiteca de Santo André, Gibiteca de Belém do Pará, Gibiteca de Fortaleza, Gibiteca de Sertãozinho (SP), entre tantas outras, o que só reforça a afirmação de Valéria Bari (2008, p. 176) sobre o aumento do número desses espaços estar relacionado aos conceitos teóricos que demonstram o quanto a leitura de histórias em quadrinhos é uma atividade que não se limita apenas ao lazer, mas a diversas outras áreas relacionadas à aquisição de bens culturais. Para Nogueira (2017), é importante ressaltar que

muitas das iniciativas de criação de gibitecas partiram, quase que exclusivamente, da ação de profissionais da área de biblioteconomia, educadores, leitores e profissionais que trabalham direta ou indiretamente com HQs. A partir de arrecadação de HQs, essas pessoas conseguem compor e organizar acervos dentro de bibliotecas e mesmo criar gibitecas independentes. (NOGUEIRA, 2017, p.98)

Ainda que haja trabalhos e pesquisas acadêmicas dedicados às gibitecas, não é possível precisar a quantidade de espaços dedicados exclusivamente à leitura de histórias em quadrinhos no país. Nogueira (2017) afirma que

fazer um mapeamento das gibitecas brasileiras não é uma tarefa fácil: Muitas vezes gibitecas são criadas em comunidades carentes como forma de incentivo à leitura, noutras, a gibiteca é um espaço anexo à biblioteca e aparece, quando citada, apenas como uma "atividade" da mesma, não nos permitindo avaliar se ela realmente existe como espaço autônomo ou corresponde tão somente a um mero amontoado de revistas velhas e desordenadas. (NOGUEIRA, 2017, p.99) 
Para Vergueiro (2005, p. 5), os últimos anos têm evidenciado a tendência de constituir gibitecas como setores de bibliotecas públicas, o que talvez aponte para uma tendência de conscientização dos governantes locais e estaduais a respeito da importância da leitura de quadrinhos como uma prática de lazer, sendo assim, vinculada às práticas culturais promovidas pelas secretarias de cultura. Nesse sentido,

assim como as bibliotecas, as gibitecas possuem, também, uma função social. Podemos estabelecer, como função social da gibiteca, a inclusão e o estímulo à leitura, criatividade e criticidade e, no caso da gibiteca escolar, acrescente-se aí a inclusão pela educação. Assim, a gibiteca não pode ser considerada tão somente uma coleção de histórias em quadrinhos disposta à consulta pública. (NOGUEIRA, 2017, p.101)

Entre as iniciativas que se destacam quanto à promoção de atividades que visam aproximar as pessoas dos quadrinhos e à formação de público leitor, é possível citar algumas que promovem eventos voltados exclusivamente aos quadrinhos, como Biblioteca São Paulo (Figura 3), indicada a um prêmio internacional na Feira do Livro de Inglaterra de $2018^{32}$ e que chama a atenção por estar localizada no prédio que servia como a antiga penitenciária do Carandiru. Hoje, abriga um acervo de revistas em quadrinhos e em sua página $^{33}$ podem ser encontradas dicas e resenhas sobre exemplares que estão disponíveis no acervo, além de uma agenda com os eventos com quadrinistas nacionais.

\footnotetext{
${ }^{32} \mathrm{https} / / /$ www.revistahabitare.com.br/arquitetura/biblioteca-sao-paulo-e-finalista-em-premiacaointernacional/

${ }^{33} \mathrm{https}: / /$ bsp.org.br/?s=Quadrinhos
} 
Figura 3 - Biblioteca São Paulo (Antiga Carandiru)

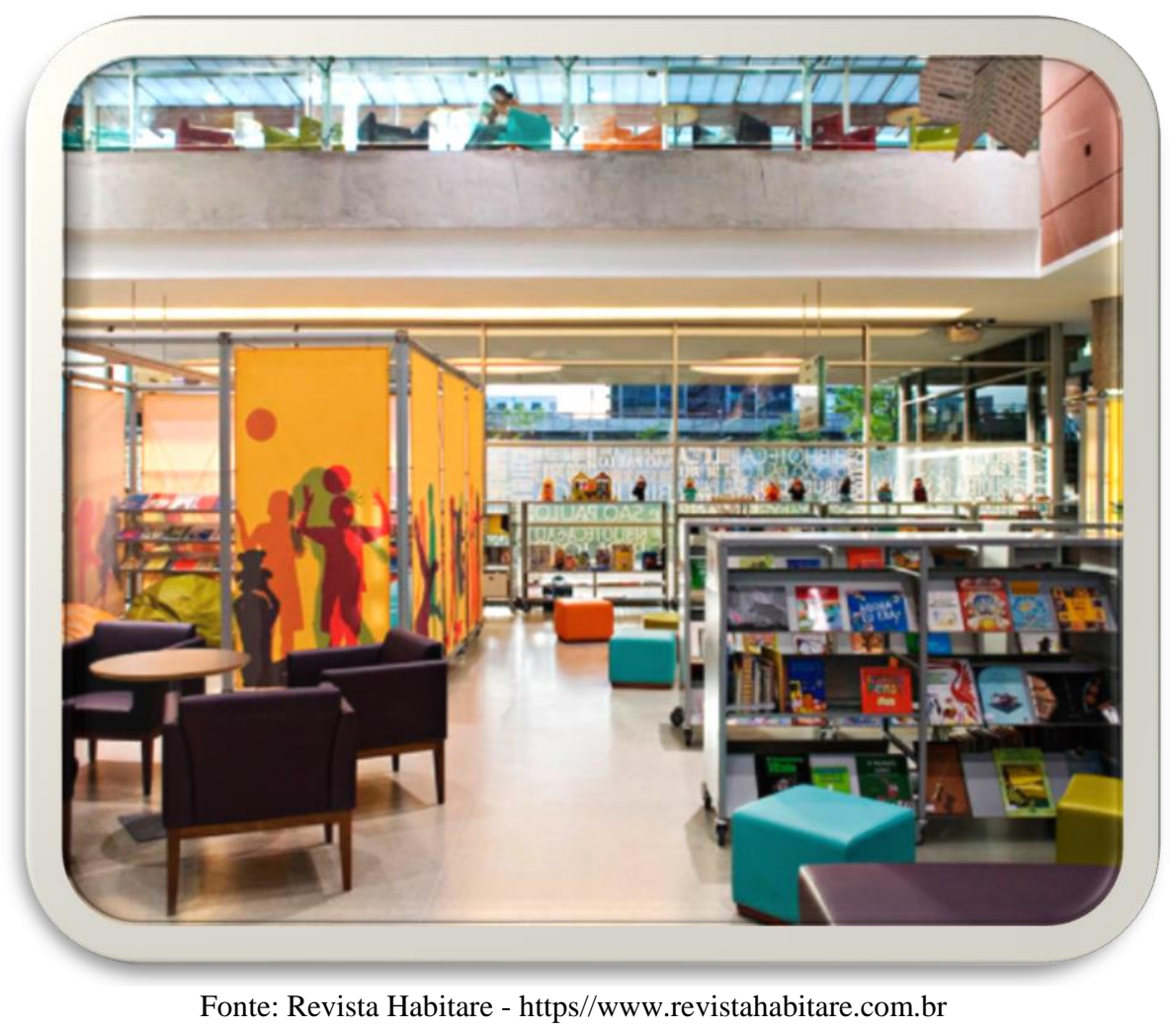

A Gibiteca de Curitiba $^{34}$ desde a sua fundação manteve uma agenda bastante ativa, com lançamentos, exposições e bate-papos com artistas nacionais e internacionais, além de diversos cursos oferecidos à comunidade, se consolidando com uma das maiores referências para leitores e pesquisadores de quadrinhos no Brasil.

Em São Paulo há a biblioteca infantil Monteiro Lobato, Biblioteca do Sesi e a Biblioteca Mário de Andrade, todas com áreas dedicadas à leitura de histórias em quadrinhos e que, eventualmente, também incluem bate-papos e lançamentos nacionais em sua programação ${ }^{35}$.

Já a Gibiteca Henfil, de São Paulo, por manter um dos maiores acervos públicos de quadrinhos do país (hoje são mais de 100.000 exemplares) e por sua localização privilegiada no Centro Cultural São Paulo, é um dos mais frequentados espaços dedicados aos quadrinhos no país, como já mencionado anteriormente. Promovendo atividades que envolvem artistas nacionais e internacionais, como Laerte Coutinho, Trina Robbins, entre outros, e realizando exposições com desenhos originais dos maiores artistas italianos, além

\footnotetext{
${ }^{34} \mathrm{http}: / /$ www.fundacaoculturaldecuritiba.com.br/espacos-culturais/gibiteca-de-curitiba/

${ }^{35} \mathrm{https} / /$ guia.folha.uol.com.br/passeios/2018/03/conheca-seis-bibliotecas-com-secoes-dedicadas-aos-fasde-quadrinhos.shtml
} 
de bate-papos sobre diversidade e acessibilidade nas histórias, cursos de desenho, o público em geral pode ter contato com as diversas etapas da produção de uma história em quadrinhos em seus mais diversos formatos e gêneros narrativos.

Em São Bernardo do Campo, SP, a mudança de endereço da Cidade da Criança para o Poupatempo, quadruplicou o número de visitantes da Gibiteca Municipal Eugênio Colonnese $^{36}$. De acordo com o então secretário de Cultura, Adalberto Guazzelli, a média de visitantes por ano no antigo local era de 5.000 pessoas, enquanto em 2017 cerca de 20.000 pessoas passaram pelo novo endereço. Com um acervo de 15.000 exemplares de quadrinhos, do qual apenas $20 \%$ corresponde a quadrinhos para o público infantil, a antiga gibiteca era mal sinalizada e não constituía um atrativo para as crianças que dispunham de brinquedos pagos no parque. Então, desde a mudança para o Poupatempo em abril de 2017, além dos exemplares voltados para o público jovem e adulto, os visitantes podem conferir também livros teóricos sobre as histórias em quadrinhos, RPGs, entre outros.

Tais práticas, como a promoção de eventos e cursos, não chegam a ser uma novidade quando se trata da interação entre um espaço que se destina à difusão cultural e o público. Museus como o Museu da Língua Portuguesa, na Estação da Luz em São Paulo, ou a Bienal de Arte de São Paulo, sempre ofereceram atividades interativas entre obras e público.

Consoni (2013, p.22) afirma que "a interação nas artes surgiu com o intuito de encurtar o distanciamento existente entre artista, obra e público" e tal ação propicia não só várias possibilidades de manipulação de uma obra, como permite que os visitantes de um espaço destinado à difusão artística possam lidar e interpretar essa obra de novas maneiras.

Assim, a julgar pelas ações realizadas por gibitecas que visam aproximar o público aos artistas e suas obras, e pelos cursos oferecidos, a ideia de que esses espaços não podem se limitar à exposição estática de seus acervos parece estar sendo compartilhada por alguns coordenadores e bibliotecários, indicando que a interação promovida nos eventos não só atrai visitantes para os locais, como também pode mostrar que tais espaços são polos de fomento de cultura pop, de aprendizado e fortalecimento de laços entre seus frequentadores.

36 http://www.abcdoabc.com.br/sao-bernardo/noticia/mudanca-quadruplica-publico-gibiteca-sao-bernardo62931 


\section{A GIBITECA MUNICIPAL DE SANTOS - MARCEL RODRIGUES PAES}

\subsection{A história da gibiteca municipal de Santos}

Fundada em 8 de dezembro de 1992, com o nome de Gibiteca Municipal de Santos, somente em dezembro de 1993 ela foi rebatizada com o nome de Marcel Rodrigues Paes, colunista de cultura do jornal A Tribuna de Santos, falecido em 30 de novembro de 1992, aos 26 anos, em decorrência de complicações da hemofilia que o acometia (Figura 4).

Marcel era formado em jornalismo pela Faculdade de Comunicação da Universidade Católica de Santos, a FACOS, e começou a trabalhar na redação de $A$ Tribuna em julho de 1988 e assinava uma coluna de cultura que saía todas as quartas-feiras. Fã incondicional de histórias em quadrinhos, não só comentava todos os lançamentos que saiam no Brasil, como também indicava como lidar com pragas mais comuns que atacavam (Figura 5) as coleções de revistas e indicava as bancas da cidade onde os leitores podiam comprar seus quadrinhos (Figura 6).

Figura 4 - Carta em homenagem a Marcel publicada no Jornal A Tribuna em 6/12/1992

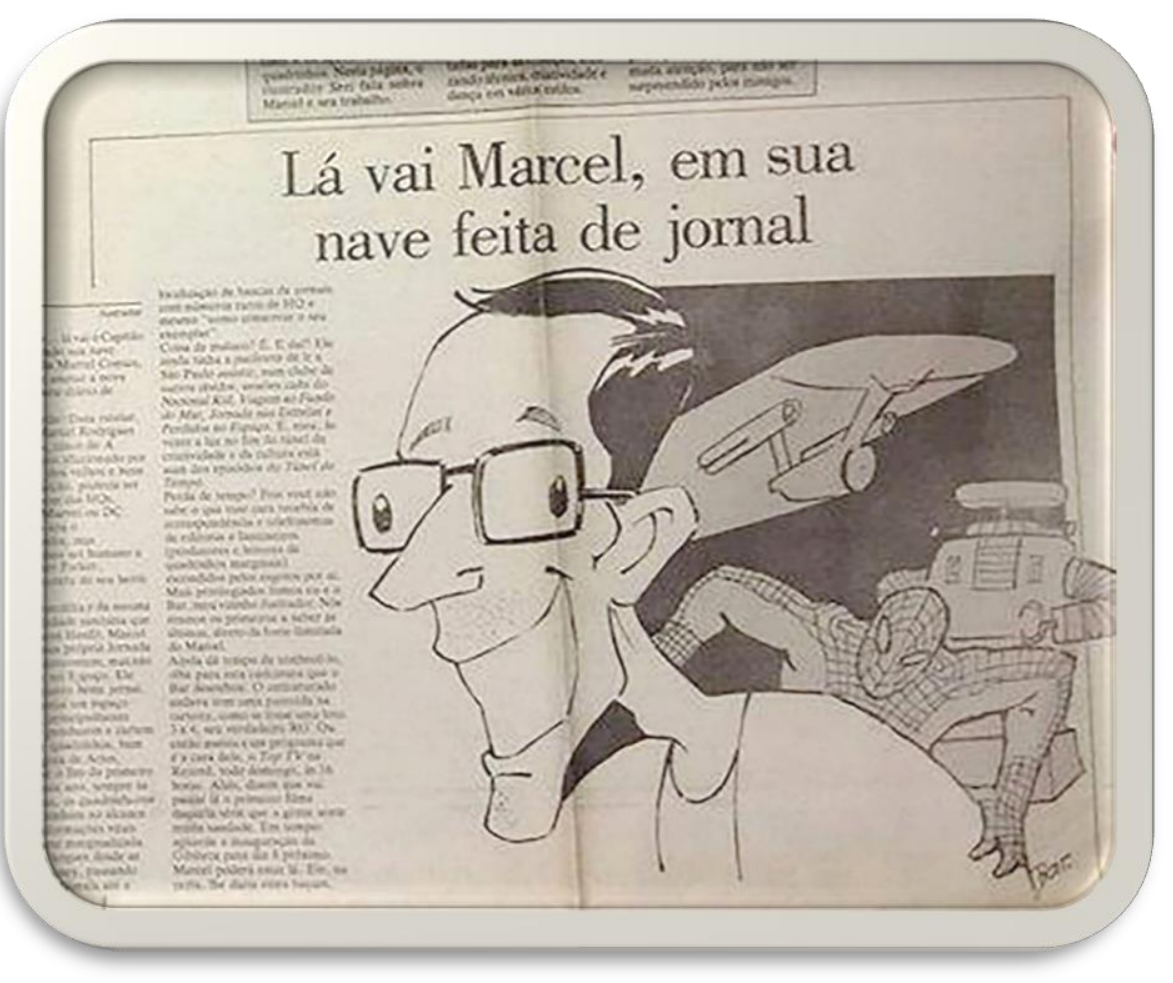

Fonte: Alexandre Barbosa - arquivo pessoal 
Figura 5 - Matéria de Marcel sobre controle de pragas das coleções de quadrinhos

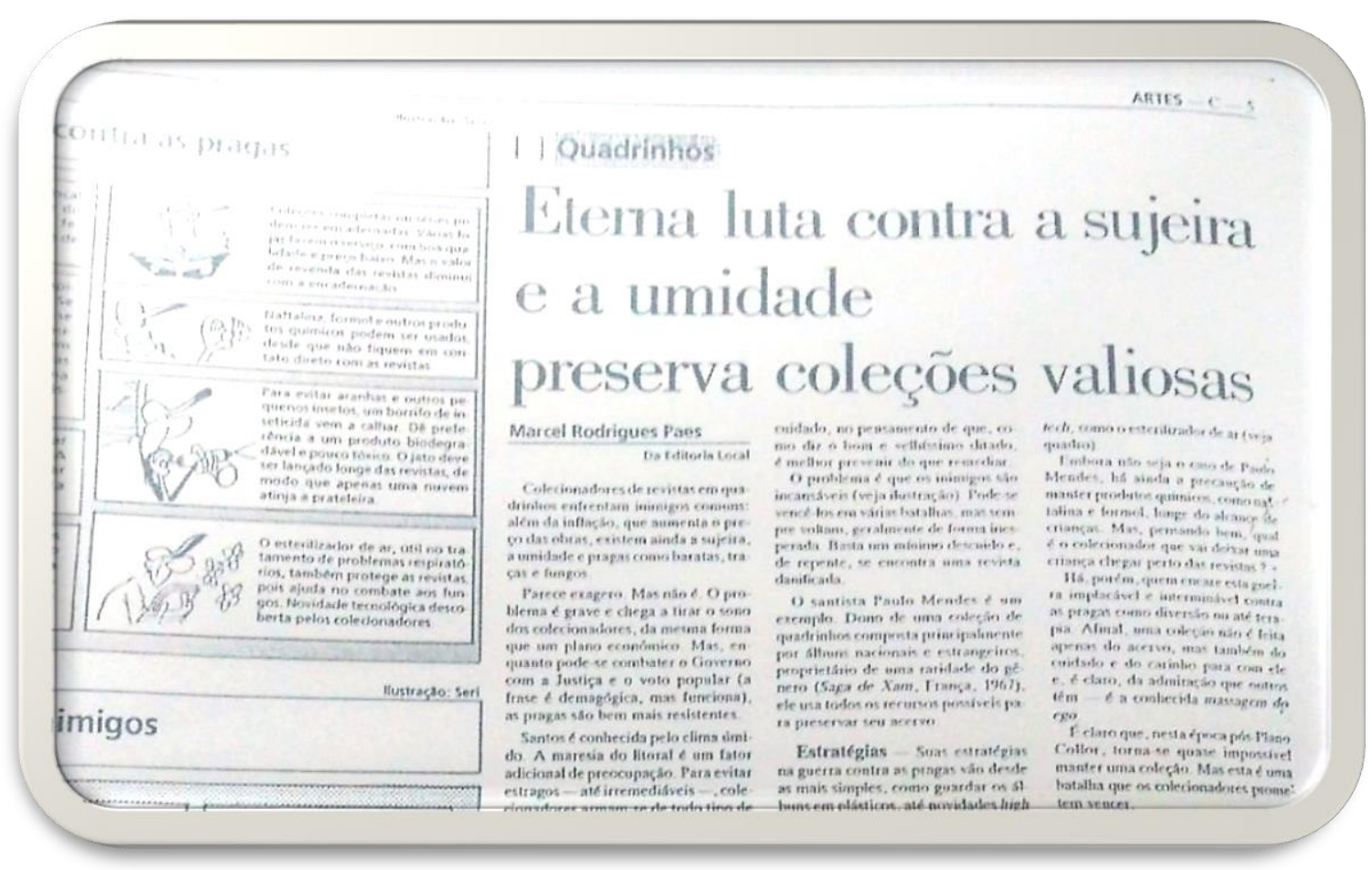

Fonte: Arquivo da Gibiteca

Figura 6 - Matéria de Marcel sobre sebos e bancas de jornal da cidade de Santos

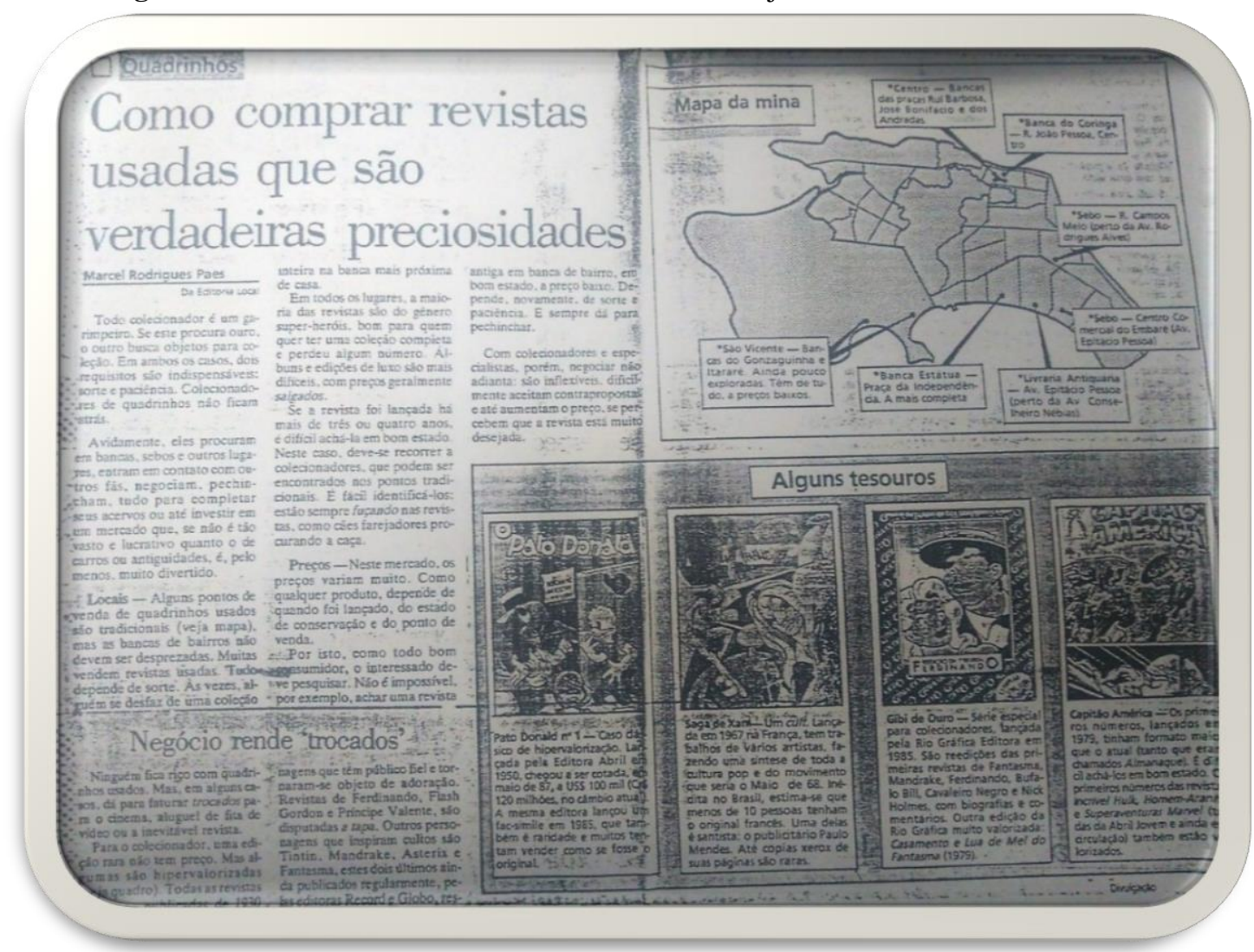

Fonte: Arquivo da Gibiteca 
A inauguração da Gibiteca fez parte de um projeto municipal de revitalização dos postos de salvamento localizados na orla da praia de Santos (Figuras 7, 8 e 9). Em sua extensão, a orla conta com sete postos de salvamento que serviam exclusivamente como postos do Corpo de Bombeiros de 1937 até 1992 (Figura 10). A partir de então, a área antes destinada como almoxarifado de produtos de salvamento em cada posto, passou a abrigar equipamentos culturais diversos, como o Posto 2, que é uma escola de esportes radicais e surf; o posto 4 que abriga o cinema de arte, o posto 6 que é uma biblioteca e o posto 5 , onde se encontra a Gibiteca (Figura 11).

Hoje, a Gibiteca de Santos é um equipamento gerido pela seção das Bibliotecas da Orla (Sebi-OR), que é um departamento da Coordenadoria de Informação e Centros Culturais dentro da Secretaria de Cultura de Santos. No organograma da SECULT ${ }^{38}$, ela aparece como um equipamento gerido diretamente pela Secretaria; no entanto, de acordo com a coordenadora do local, Narayana Fida Mamede, a gestão da Gibiteca está sujeita a vários departamentos: Gibiteca < Sebi-Or (Seção de Bibliotecas da Orla) < COCEC (Coordenadoria de Informação e Centros Culturais) < DEFORPEC (Departamento de Formação e Pesquisa Cultural) < SECULT.

Figura 7 - Matéria sobre a inauguração da Gibiteca no jornal A Tribuna em 09/12/1992

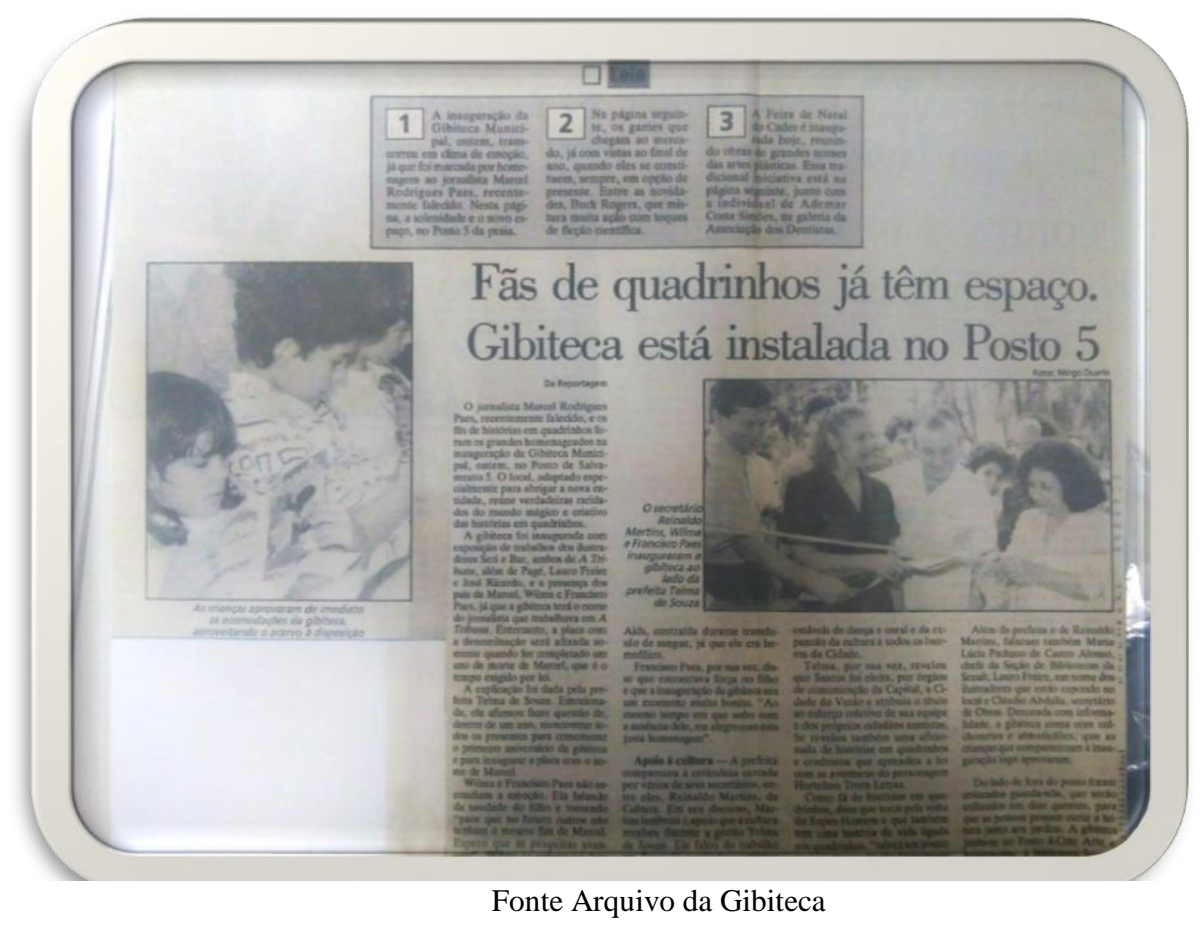

\footnotetext{
${ }^{37}$ http://www.novomilenio.inf.br/santos/fotos349.htm

${ }^{38}$ https://egov1.santos.sp.gov.br/organograma/\#SECULT
} 
Figura 8 - Convite da inauguração da Gibiteca - dezembro de 1992

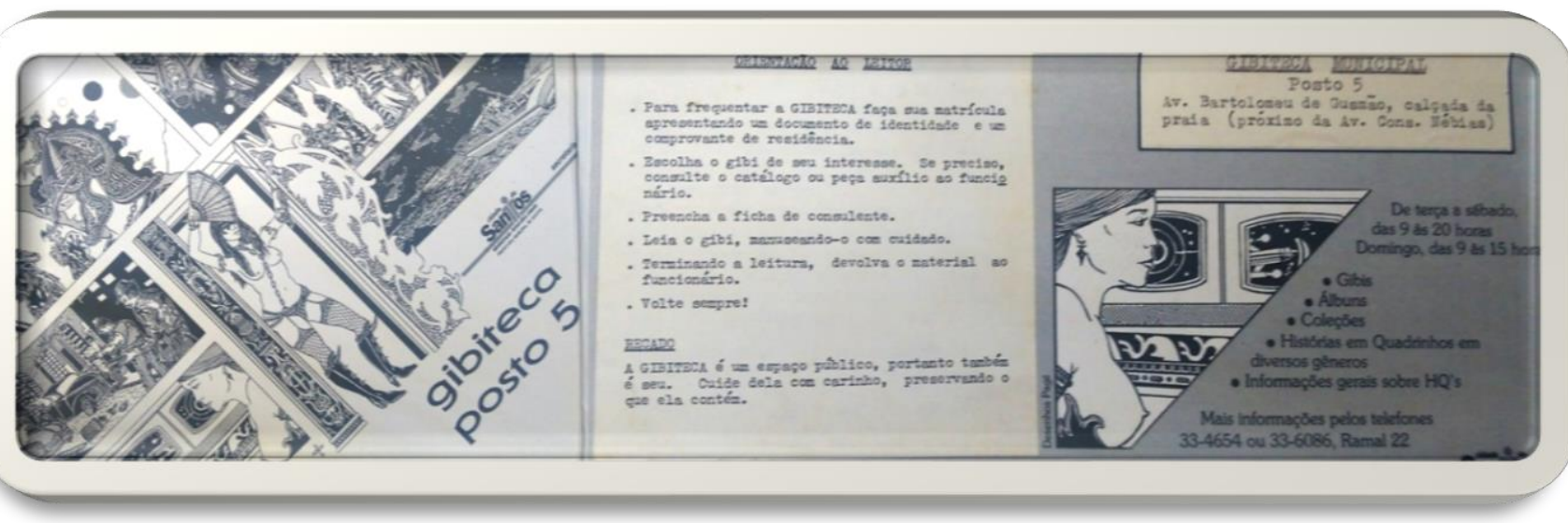

Fonte: Arquivo da Gibiteca

Figura 9 - Espaço interno da Gibiteca em 1993

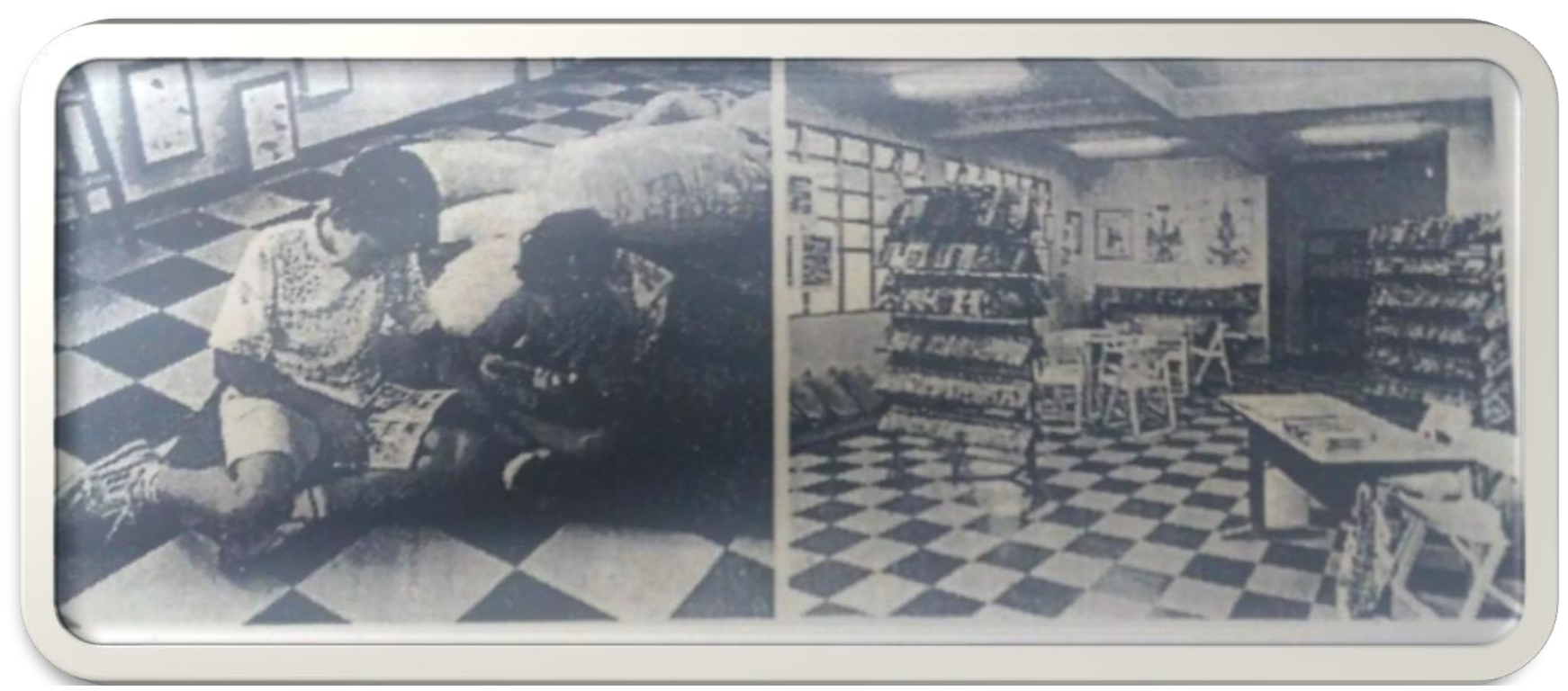

Fonte: Arquivo da Gibiteca 
Em 2010, todo o jardim de 5.335 metros de extensão e $218 \mathrm{mil} \mathrm{m}^{2}$ da orla marítima de Santos foi tombado pelo Conselho de Defesa do Patrimônio Histórico e Arqueológico, Artístico e Turístico do Estado (Condephaat) ${ }^{39}$. Essa área compreende também todos os postos de salvamento, garantindo a preservação do espaço físico onde a Gibiteca é mantida.

Figura 10 - Como eram os postos de salvamento na época de sua inauguração

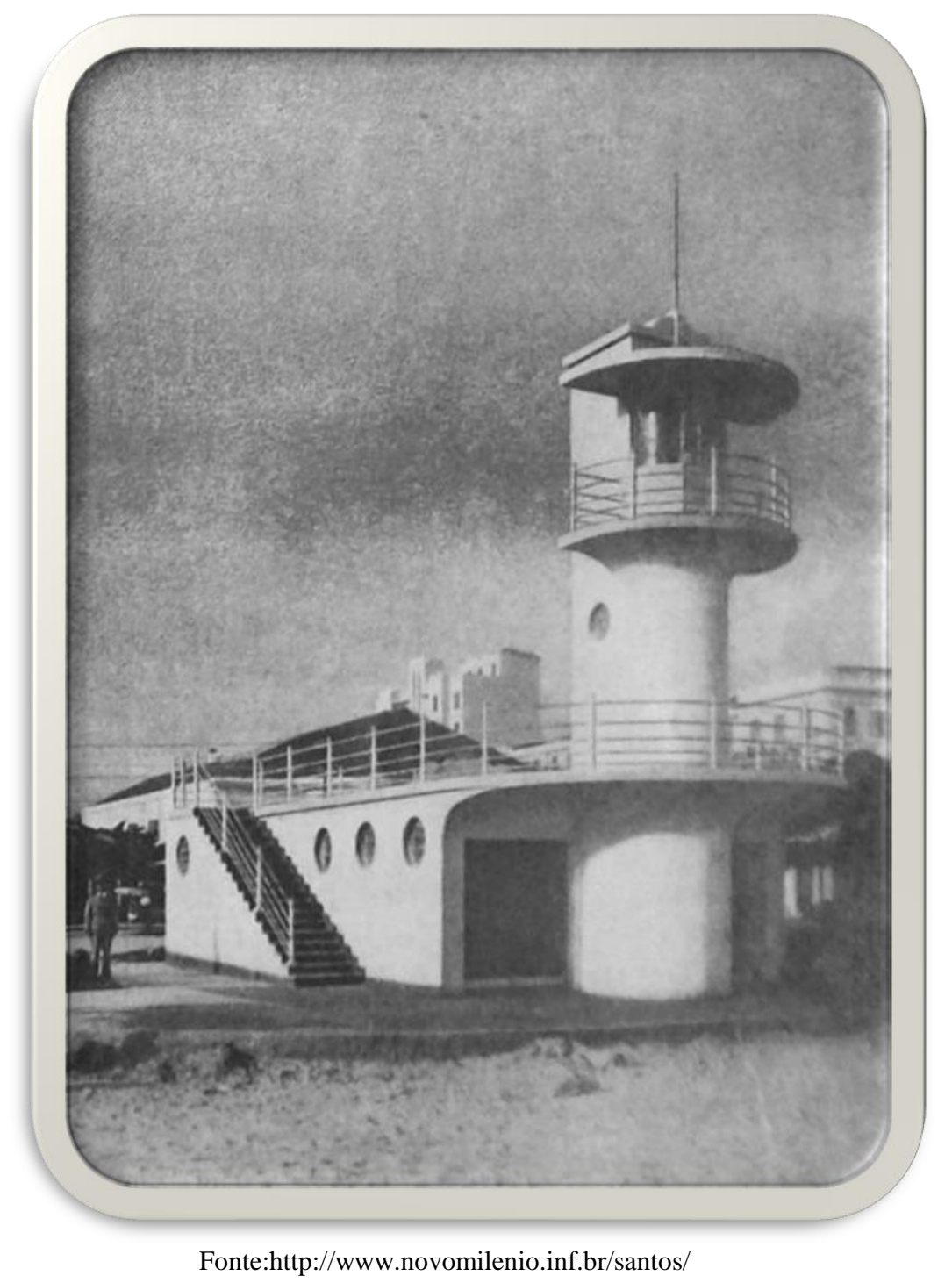

\footnotetext{
${ }^{39} \mathrm{http}$ //sao-paulo.estadao.com.br/noticias/geral,tombada-a-orla-de-santos-a-maior-do-mundo-imp-,580404
} 
Figura 11 - Posto de Salvamento que abriga a Gibiteca Municipal de Santos

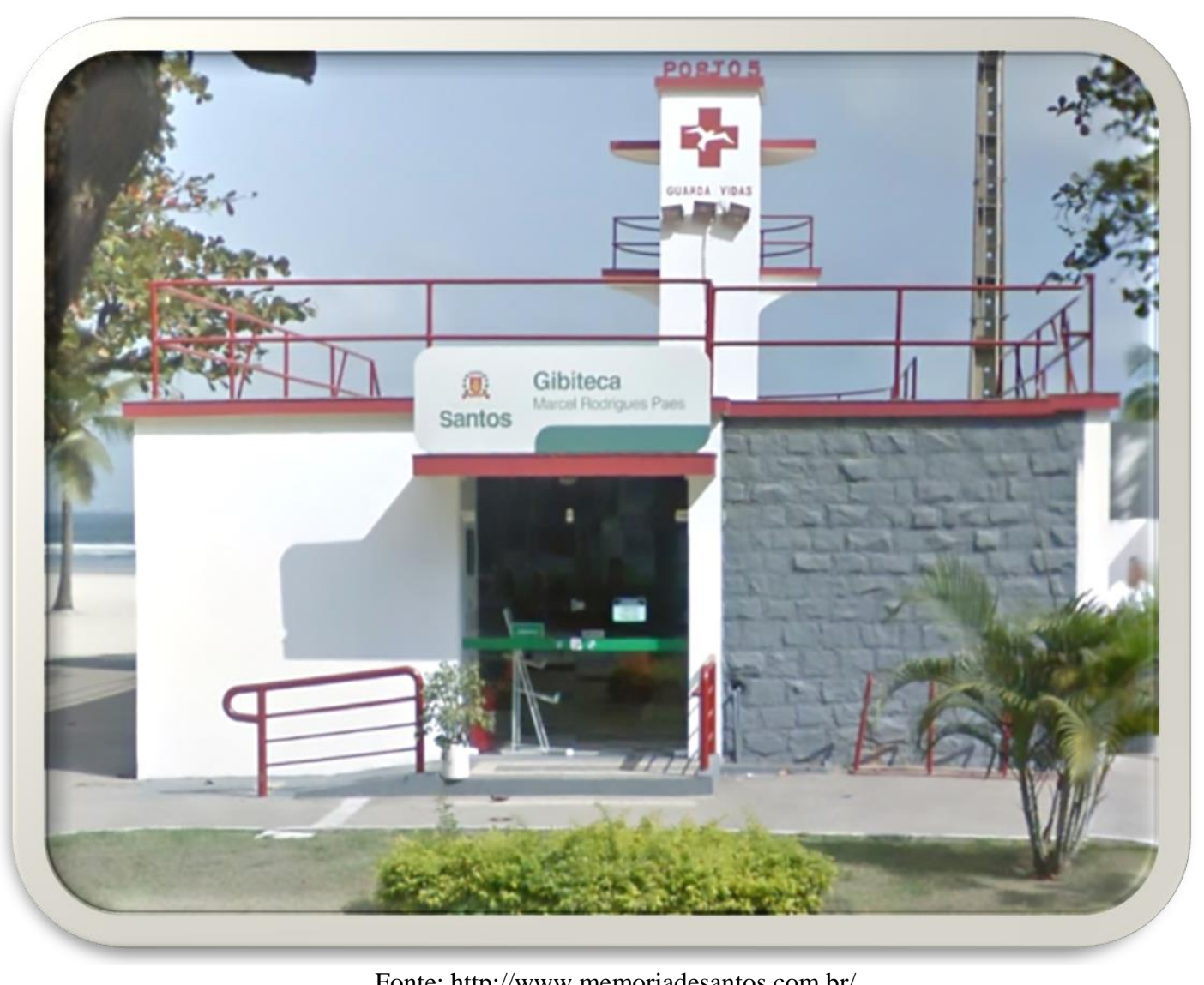

Fonte: http://www.memoriadesantos.com.br/

Em 19 de fevereiro de 2015 ela foi fechada para reformas e para a instalação de seu primeiro ar-condicionado. Reaberta em 31 de maio do mesmo ano, com nova pintura, o espaço continuou apresentando dificuldades quanto ao acondicionamento e organização das revistas em quadrinhos, e outros problemas relacionados à segurança do local, que frequentemente tem as maçanetas de suas portas roubadas.

Documentos que demonstram não só a justificativa para a criação da Gibiteca, como também sua constituição inicial, podem ser consultados no local. O arquivo com informações de interesse histórico é composto basicamente de matérias de jornais, que cobrem desde a abertura da Gibiteca, incluindo o convite original enviado às autoridades (Figura 8), imprensa e artistas locais, aos eventos divulgados até hoje.

Por meio desse arquivo que é possível constatar que o problema de segurança não é recente, já que existe um boletim de ocorrência de outubro de 1995 que registra ofensas contra funcionários e brigas no local. De acordo com a atual coordenadora da Gibiteca, as almofadas e cadeiras que estavam disponíveis no projeto inicial, tiveram que ser trocadas 
por mesas e cadeiras para melhor acomodar as novas estantes que foram trazidas na medida que o acervo foi aumentando. Ela ainda lembra que até 2010, a Gibiteca possuía assinatura mensal dos principais lançamentos da Turma da Mônica, Marvel e DC e que só a partir de 2011 que as doações passaram a ser a única forma de aumentar o acervo ${ }^{40}$.

Santos é uma cidade que possui diversas ações voltadas à leitura e à cidadania, no entanto, a Gibiteca Marcel Rodrigues Paes, por ter uma localização privilegiada (no jardim da praia), acesso gratuito e eventos que ocorrem nos finais de semana com maior frequência a cada ano, costuma ter destaque na mídia local, como no jornal A Tribuna, onde podem ser encontrados 219 entradas sobre os eventos ocorridos desde 2014 em seu site quando buscamos por "gibiteca" 41 .

O destaque se deve também à realização de ações sociais específicas voltadas à formação de público leitor de quadrinhos, como o Baú da Gibiteca, realizado desde 2015. $\mathrm{O}$ projeto de incentivo à leitura da Secretaria de Cultura, por meio de histórias em quadrinhos, chega a doar em média 250 revistas em quadrinhos às escolas, todas provenientes de doações feitas à Gibiteca Municipal Marcel Rodrigues Paes. Publicações variadas como quadrinhos infantis (Disney e Turma da Mônica), revistas de super-heróis e mangás passam a fazer parte dos acervos. Em 2016 o projeto contabilizou treze baús entregues às escolas municipais de Santos.

Em dezembro de 2014 a Gibiteca Municipal de Santos Marcel Rodrigues Paes comemorou vinte e dois anos de existência com uma celebração à qual compareceram visitantes habituais, a mãe do colecionador de quadrinhos homenageado, Marcel Rodrigues Paes, e políticos locais. A comemoração marcava não só o aniversário do equipamento municipal, que é administrado pela Secretaria de Cultura de Santos, mas o anúncio de sua esperada reforma ${ }^{42}$ e do número de eventos realizados naquele ano: a Gibiteca realizou 108 eventos somente em 2014 contra apenas 18 realizados em 2012. Em 2015 foram mais 106 atividades realizadas, o que rendeu ao local o prêmio Jayme Cortez de incentivo ao quadrinho nacional na 32a edição do Troféu Angelo Agostini, realizado no dia 30 de janeiro de 2016. De acordo com o responsável pelo local na época, Fábio Tatsubô,

\footnotetext{
${ }^{40}$ Informações fornecidas presencialmente por Narayana Fida Mamede, coordenadora atual da Gibiteca

${ }^{41}$ Busca realizada em 02/05/2018

${ }^{42} \mathrm{http} / / / q u a d r o-a-q u a d r o . b l o g . b r / r e a b e r t u r a-d a-g i b i t e c a-d e-s a n t o s /$
} 
a premiação do Angelo Agostini é um reconhecimento da importância das gibitecas. Hoje, as gibitecas não podem mais ser somente uma caixinha de gibis, elas precisam ser tornar polos irradiadores para a formação de público leitor, iniciação e formação artística, valorização dos cartunistas locais e integração com os artistas de reconhecimento nacional. É criar ambientes propícios para o desenvolvimento do segmento na cidade. E o Angelo Agostini nos dá a oportunidade de debater sobre isso, da estrutura aos investimentos no equipamento e principalmente, que no ano que vem, outras gibitecas do país possam estar concorrendo ao Troféu. ${ }^{43}$

Esses eventos, que envolvem desde debates e encontros com quadrinistas à contação de histórias e rodas de leitura para crianças, contribuem para que a Gibiteca de Santos receba destaque local nos veículos de imprensa, como o jornal A Tribuna, Jornal da Orla, TV Tribuna, entre outros. Seu acervo, hoje em torno de 30.000 títulos, pode ser consultado no local e é mantido por meio da doação de revistas pelos artistas e frequentadores do espaço. Para Mauricio de Sousa, da Mauricio de Sousa Produções,

as gibitecas deveriam se espalhar pelo país principalmente para o lazer e até alfabetização de crianças e jovens. A história em quadrinhos ainda é o brinquedo mais barato, que diverte e traz conteúdo. A Gibiteca de Santos é um exemplo nesse sentido porque não apenas tem bom acervo, mas procura ter uma programação de debates, exposições e oficinas de quadrinhos para seus frequentadores. Com direção de quem é do ramo, até presta assessoria aos desenhistas sobre leis de incentivo para conseguirem publicar seus quadrinhos. Ainda é localizada na praia. (DIÁRIO OFICIAL, 2014, p. 4)

Com a perspectiva da publicação de adaptações literárias por meio de editais públicos, muitos artistas têm optado por este meio para conseguir divulgar seus trabalhos, podendo posteriormente lançar outras obras de forma independente. Em editais de fomento à cultura como o Proac (SP), por exemplo, parte da produção deve ser destinada ao abastecimento de escolas públicas da rede estadual e bibliotecas como contrapartida de um projeto. Quando a escola dispõe de uma gibiteca, essas revistas integram seu acervo;

\footnotetext{
${ }^{43}$ Fábio Tatsubô, coordenador da Gibiteca de Santos em: http://quadro-a-quadro.blog.br/32-trofeu-angeloagostini/
} 
quando não, fazem parte da biblioteca tradicional, como explicado pelo desenhista Mario Cau em bate-papo realizado na Gibiteca de Santos, em fevereiro de $2014^{44}$.

\subsection{Os eventos realizados na gibiteca de Santos}

Entre os apontamentos de Pustz (2000, p. 157-198) sobre a importância da realização dos eventos específicos de histórias em quadrinhos, está a satisfação de se sentir parte de algo. No capítulo cinco de seu livro Comic Book Culture: Fanboys and True Believers, o autor discorre sobre as origens da cultura das histórias em quadrinhos e sobre os tipos de interação que fazem com que os fãs e leitores se sintam próximos de seus personagens e criadores favoritos.

Da seção de cartas dos leitores às Comic Cons, essa interação envolve hoje eventos presenciais e discussões nas redes sociais, fomentadas por sites como os americanos Comics Journal ${ }^{45}$, Comic Buyer's Guide ${ }^{46}$ e Wizard: The Guide to Comics $^{47}$ (PUSTZ, 2000, p. 178). São os sites e fan pages que divulgam as publicações, promovem eventos e fazem resenhas sobre os títulos lançados no mês. No Brasil, sites como o Universo $H Q^{48} \mathrm{e}$ Omelete $^{49}$ são alguns dos espaços virtuais dedicados à divulgação de programas e eventos voltados aos quadrinhos.

Nesse sentido, o que se observa no Brasil, é um aumento da oferta de diferentes gêneros narrativos dentro das histórias em quadrinhos, como coletâneas inteiras dedicadas a quadrinhos de terror, hip hop ou ficção científica, por editoras como a Draco, por exemplo, gerando um "processo de segmentação que ocorre a partir das redes sociais, com a constituição de coletivos de autores com determinadas preferências temáticas ou de gênero" (VERGUEIRO, 2017, p.167):

\footnotetext{
${ }^{44}$ http://quadro-a-quadro.blog.br/lancamento-coletivo-na-gibiteca-de-santos-15-02-14/

${ }^{45}$ http://www.tcj.com/

${ }^{46} \mathrm{http}: / / \mathrm{www}$.antiquetrader.com/comics-buyers-guide/

${ }^{47}$ Revista impressa até 2011, anunciou retorno em versão digital em 2017: https://www.newsarama.com/35982-wizard-magazine-returns.html

${ }^{48}$ http://www.universohq.com/

${ }^{49} \mathrm{https} / / / \mathrm{m}$. omelete.uol.com.br/quadrinhos/artigo/estoques-dos-quadrinistas-esgotam-no-terceiro-dia-de$\operatorname{ccxp/}$
} 
Assim, amplia-se a produção de quadrinhos realizada e destinada a mulheres, com o aparecimento de produtoras que refletem sobre sua realidade e produzem quadrinhos com características próprias, evidenciando as possibilidades de a Nona Arte atingir os mais distintos públicos. (VERGUEIRO, 2017, p. 167)

Paralelamente à maior diversidade e ao advento da internet que propiciaram intercambio de trabalhos e compartilhamento de ideias, eventos de cultura pop de grande porte começaram a ocorrer no país, principalmente a partir dos anos 2000, com a chegada de feiras como a Comic Con Experience, seguindo nos moldes das comic cons norteamericanas.

Esses eventos promovem oficinas e disponibilizam espaços para que os artistas nacionais e internacionais de quadrinhos comercializem e divulguem seus trabalhos. Para Vergueiro (2017), ainda que possam ser feitas críticas aos moldes destes eventos, eles representariam uma inserção do país no movimento internacional de cultura pop, valorizando os produtos que dela fazem parte, como os quadrinhos:

Ao incorporar os autores nacionais nesse circuito - tratando-os, com maior ou menor dignidade, dependendo do evento - como agentes importantes de produção cultural, essas convenções concorrem para o desenvolvimento de um sentimento de valor próprio e para a aproximação maior do autor nacional do seu público. Qualquer um que visite um desses eventos, pode perceber que o interesse dos visitantes já não se prende apenas aos convidados internacionais, mas se estende também aos autores brasileiros, que comparecem com novas obras, lançamentos e produtos, estreitando relações desenvolvidas tanto por produções impressas como também por atividade de promoção pessoal realizada via redes sociais. (VERGUEIRO, 2017, p.166)

Além dos eventos dedicados aos quadrinhos no Brasil, tanto na área do entretenimento como no meio acadêmico, as franquias cinematográficas e séries das redes de streaming, como Netflix ${ }^{50}$, também têm em seu catálogo não só documentários sobre quadrinhos, como obras dedicadas a contar a história da Nona Arte.

\footnotetext{
${ }^{50} \mathrm{http}: / /$ deliriumnerd.com/2016/04/18/quadrinhos-especiais-sobre-quadrinhos-na-netflix/
} 
Em relação à cidade de Santos, pesquisa realizada pelo site Amazon.com em 2016, revelou que ela "é a quinta cidade mais nerd do País, perdendo apenas para Florianópolis (SC), Niterói (RJ), Santana de Parnaíba (SP) e São Caetano do Sul (SP)"51 . A informação, obtida por meio do número das vendas de quadrinhos e itens relacionados ao universo da cultura pop enviados para Santos, revela que a cidade abriga uma quantidade considerável de admiradores de histórias em quadrinhos, o que levou a secretaria de turismo da cidade a realizar o primeiro Santos Criativa-Festival Geek, que dedicou um local específico para a venda e exposição de quadrinhos, além de reservar diversos horários para a realização de painéis sobre o tema.

Os termos "nerd" e "geek" costumam estar associados e, embora apresentados de forma pejorativa nas produções cinematográficas norte-americanas dos anos 1980, quando fãs de produtos de cultura pop eram representados como rapazes geralmente sem habilidades sociais e dotados de muita inteligência, "nerds e geeks são pessoas com grande conhecimento e, também, com grande envolvimento em produtos de cultura pop e da tecnologia" (PEGORARO, 2016, p.173), que costumam representar fonte de lucros para a indústria cultural.

Entre 2013 e 2016 foram realizadas 445 (Anexo 1) atividades na Gibiteca de Santos, divididos entre: bate-papos, painéis e lançamentos de quadrinhos, exposições, eventos geek (jogos de RPG, de tabuleiro, competições de videogame e desfiles de cosplay), oficinas e aulas, feiras de trocas de gibis, doações de revistas em quadrinhos para escolas e doações recebidas.

O que se observa a partir dos dados fornecidos pela coordenação da Gibiteca (Anexo 1), é que ainda que o número de atividades realizadas em 2015 e 2016 tenha sido praticamente o mesmo, a quantidade de pessoas que passaram pelo local nos dias em que foram realizados os eventos e cursos aumentou de 1150 para 1444 de um ano para o outro, significando uma diferença ainda maior se comparada aos anos de 2013 e 2014 (Figura 13). Porém, a quantidade de leitores nos outros dias, diminuiu entre 2013 e 2015, o que pode ter ocorrido em função da reforma da Gibiteca: 4979 visitantes em 2014, 2521 em 2015 e 3813 em 2016 (Figura 12). A comparação dos números enviados demonstra diminuição de frequência do público em geral nos dias úteis, mas um aumento no número

\footnotetext{
${ }^{51} \mathrm{http}: / / \mathrm{www}$.boqnews.com/etc/considerada-a-quinta-cidade-mais-nerd-santos-demonstra-crescimento-dacultura/
} 
de visitantes nos dias em que são realizadas as atividades. No entanto, tratam-se de números aproximados, uma vez que o controle dos visitantes não é realizado de forma precisa.

Figura 12 - Gráfico de atividades realizadas na Gibiteca entre 2009 e 2016.

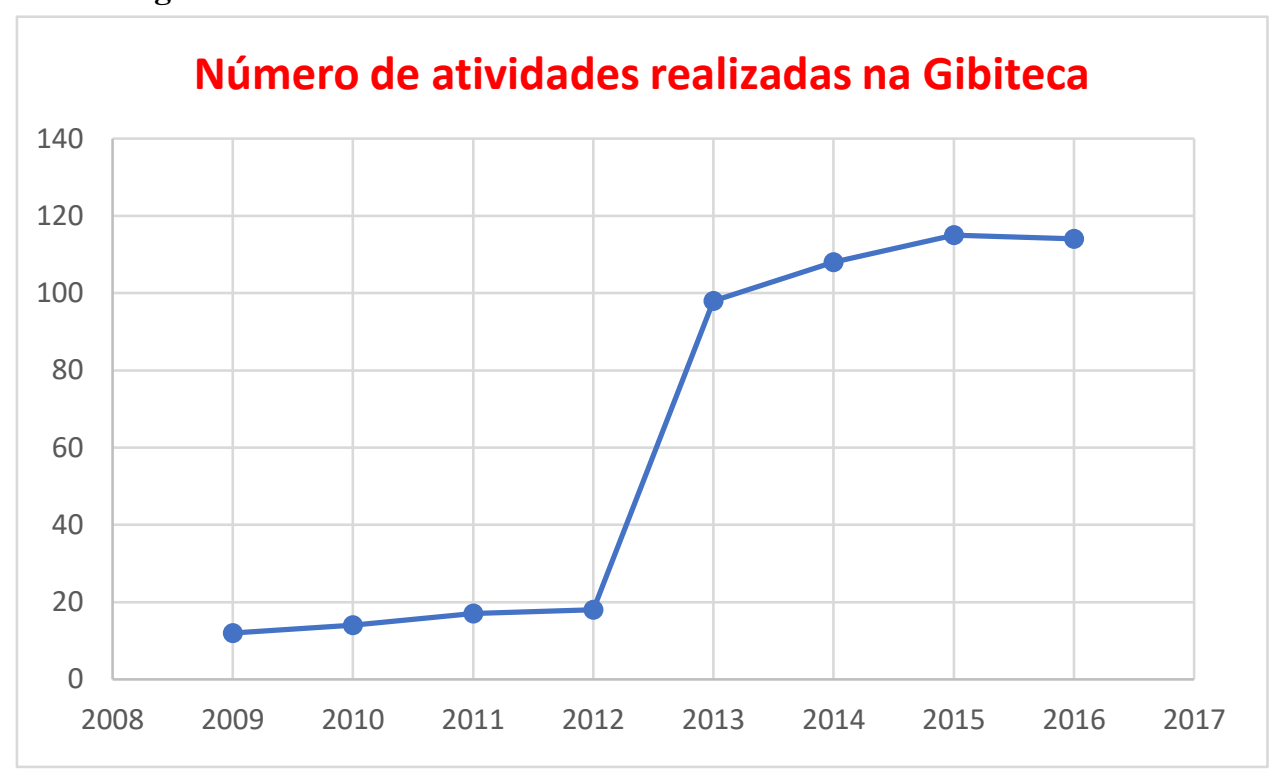

Fonte: Gibiteca de Santos

Figura 13 - Gráfico do número de participantes das atividades realizadas na Gibiteca entre 2013 e 2016.

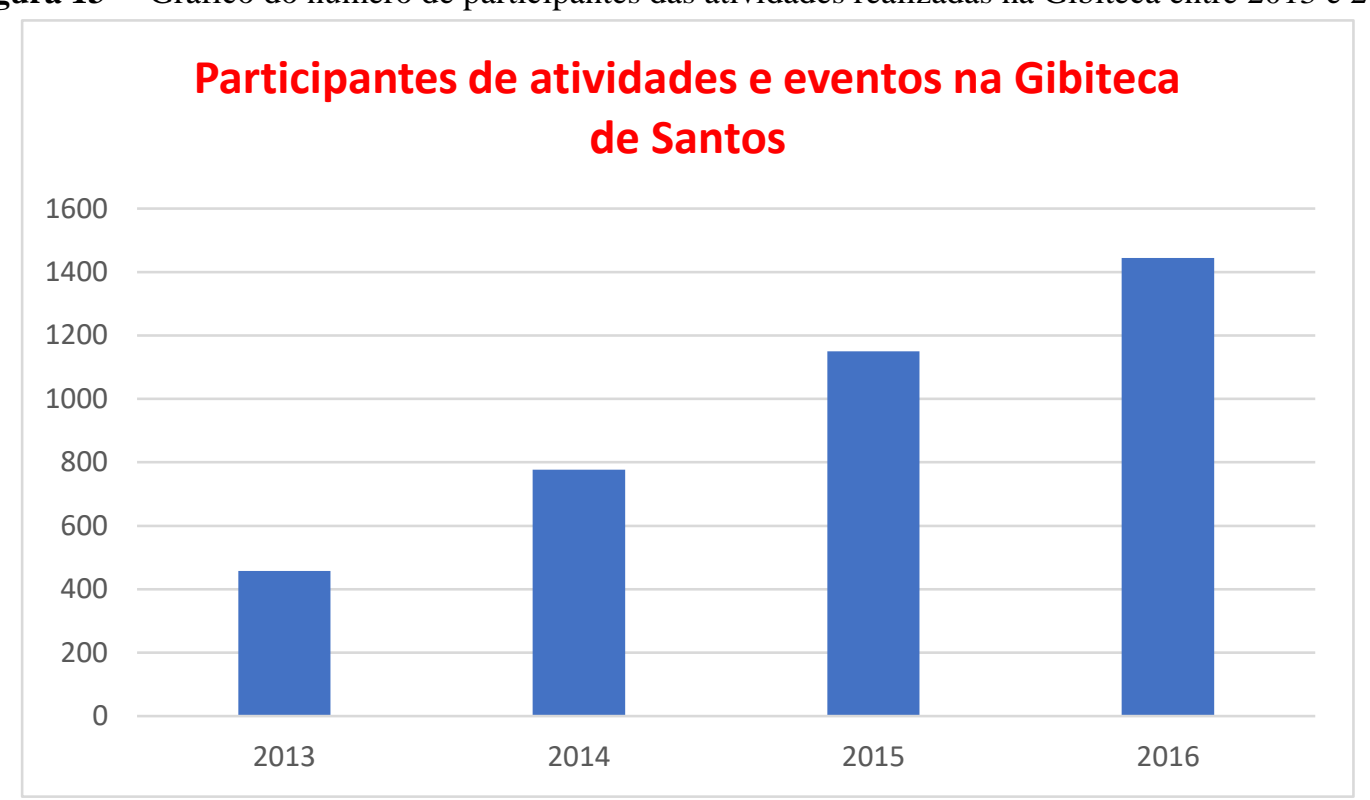

Fonte: Gibiteca de Santos

Quanto à perspectiva dos processos de compartilhamento de significados que podem ser observados entre os consumidores de quadrinhos, uma prática em especial poderia ajudar a compreender porque o número de visitantes em dias úteis na Gibiteca diminuiu: a leitura de scans pode estar entre os responsáveis por isso. Scans são versões 
digitalizadas de histórias em quadrinhos mainstream e que, além de serem ilegais, por ferirem os direitos autorais em diversos países, têm sido um problema para editoras no mundo todo, em alguns casos comprometendo as vendas dos títulos originais ${ }^{52}$.

Em relação aos visitantes da Gibiteca, o número de participantes nos dias de eventos realizados aponta que sua frequência tem aumentado, indicando uma tendência oposta ao que se observa em relação às visitas nos dias úteis, exclusivamente para a leitura das revistas. Ou seja, se por um lado os fãs não precisariam se deslocar a um espaço público para leitura gratuita de suas revistas favoritas, por outro, como também pode ser observado nas respostas do questionário (Apêndice A), a possibilidade de aperfeiçoar o conhecimento sobre técnicas de desenho, conhecer os quadrinistas e encontrar pessoas que compartilhem do mesmo interesse pelas histórias em quadrinhos, pode contribuir para que os leitores continuem frequentando esses espaços.

\subsubsection{Bate-papos e lançamentos}

Os bate-papos e lançamentos de histórias em quadrinhos são realizados nos fins de semana com artistas convidados e um mediador, geralmente um funcionário da Gibiteca ou um jornalista local. Os temas são variados, mas sempre pertinentes à produção de quadrinhos. Assim, quadrinistas, editores, roteiristas, fãs, pesquisadores, compartilham suas experiências com o público e, em seguida, os presentes podem fazer perguntas. Esse tipo de evento dura em média duas horas, sendo realizado no fim da tarde de sábado ou domingo, sempre divulgado na mídia local e no Diário Oficial da cidade (Figura 14).

\footnotetext{
${ }^{52}$ https://nosbastidores.com.br/panini-comics-solicita-remocao-de-scans-ilegais-no-brasil/
} 
Figura 14 - Matéria do Diário Oficial - 8/12/2014

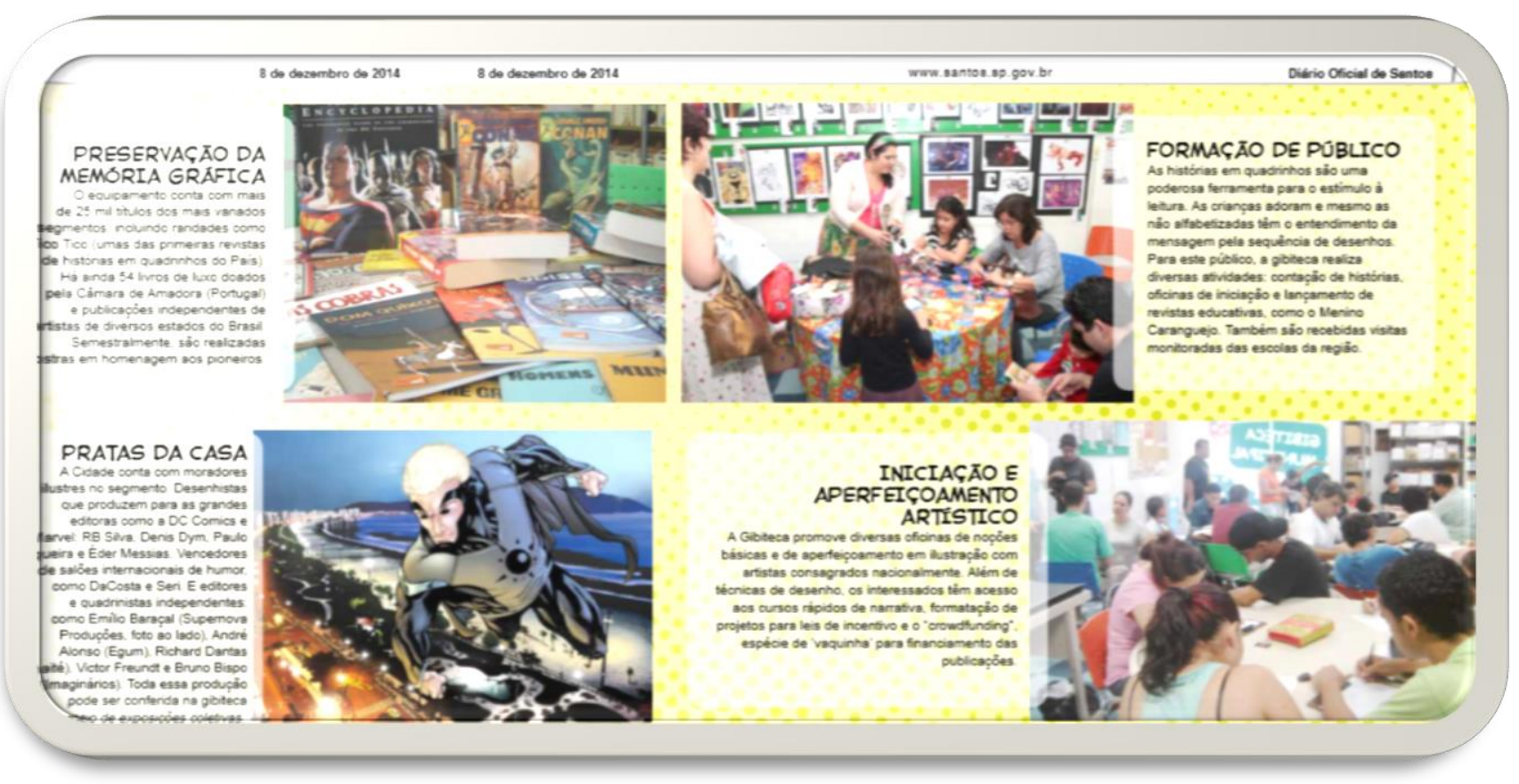

Fonte: site do Diário Oficial de Santos

Ainda que existam cadernos de visitas que ficam disponíveis para que os frequentadores assinem, até 2014 esse controle era feito mensalmente, não por evento. No entanto, a preocupação quanto à quantidade de pessoas presentes na Gibiteca por dia, nunca fez parte da rotina de seus funcionários e nem estes cadernos estão dispostos de maneira a que todos os visitantes vejam se sintam impelidos a assinar. Assim, os números apresentados pela coordenação em cada relatório, refletem um número aproximado, uma vez que nem todas as pessoas que frequentam o espaço costumam assinar o caderno. A partir de 2015, a Gibiteca passou a contar com um caderno de visitas exclusivo para registrar o número de pessoas por evento. Assim, medidas simples como a conscientização dos funcionários quanto à importância de se registrar o número de visitantes diariamente ou a instalação de uma catraca na entrada do local, poderiam assegurar maior precisão em relação ao número de pessoas que passam por lá.

O principal objetivo dos bate-papos e debates é aproximar o público dos artistas de quadrinhos, tanto para que conheçam o processo de produção, como também para que saibam quais são os percalços e dicas que podem ser compartilhados por quem já está no mercado há mais tempo, como são os casos de Laerte Coutinho, Gustavo Duarte, Camila Torrano, Mariana Cagnin, Ivan Reis, Marcatti, Laudo Ferreira, Daniel Esteves, Germana Viana, entre outros (Anexo 2). 
Além de discussões específicas sobre determinados títulos e lançamentos de quadrinhos, também são promovidos painéis com temas variados, como "Mulheres nos Quadrinhos", "Ditadura e Censura nas publicações alternativas", "O mercado nacional", "Como projetar seu trabalho no exterior", "Quadrinhos de terror", "Liberdade de Expressão".

Maia (2012 p. 21) atesta a importância e a relevância do compartilhamento de experiências nos eventos, afirmando que se trata de um meio de se atingir um bem comum. A autora acredita que a emoção é indispensável para motivar os sujeitos a tematizarem sobre suas vivências e a se engajarem na troca argumentativa: A empatia e outras "emoções altruístas" podem ajudar os sujeitos a
"assumirem idealmente o lugar do outro" (ideal role-taking), o que é
essencial para o bom raciocínio em questões de interesse público. [...] os
sentimentos de cuidado, de preocupação, de compaixão ou, ainda, de
solidariedade podem aperfeiçoar a compreensão da posição do outro e,
assim, permitir a produção de uma decisão moral justa. Mesmo que o
discurso seja orientado por regras gerais, a prática de "assumir
reciprocamente o lugar do outro", envolve uma sensibilidade empática
para com o outro concreto, bem como uma atenção para as
particularidades da situação real. (MAIA, 2012, p. 21)

No dia 14 de maio de 2016 a Gibiteca sediou um bate-papo sobre super-heróis. Com mediação do jornalista André Rittes e participação de Marco Aurélio, um dos organizadores da Santos Comic Expo, e Emílio Baraçal, roteirista de quadrinhos da Supernova Produções, a discussão girou em torno das expectativas, gostos, decepções e polêmicas do universo dos super-heróis.

As discussões sobre as adaptações para séries e cinema que costumam ocorrer na Gibiteca de Santos, corroboraram o que Pustz (2002) afirma quanto ao conhecimento específico pertinente à cultura dos quadrinhos, indicando que uma pessoa "não-iniciada" nesse universo não poderia contribuir com colocações acerca dos elementos dos quadrinhos que foram ou não adaptados adequadamente, de acordo com as expectativas dos fãs.

Para Martin-Barbero (2000), essas trocas, o compartilhamento de informações, os questionamentos e, consequentemente, possíveis conclusões, são resultados de interações que ocorrem dentro de um contexto específico que são fundamentais para a compreensão dos processos comunicacionais que ocorrem na América Latina.

No dia 26 de junho de 2016 o bate-papo foi sobre o mercado internacional de quadrinhos e como fazer para publicar no exterior (Figura 15). Com a presença de artistas 
locais que produzem para o mercado norte-americano, para editoras como Marvel e DC Comics, os participantes puderam ter acesso a dicas sobre os caminhos percorridos pelos artistas, bem como uma consultoria sobre como montar um portfólio profissional para a apresentação a agentes, editores e roteiristas.

Figura 15 - Bate-Papo sobre Mercado Internacional de Quadrinhos em 26/06/2016

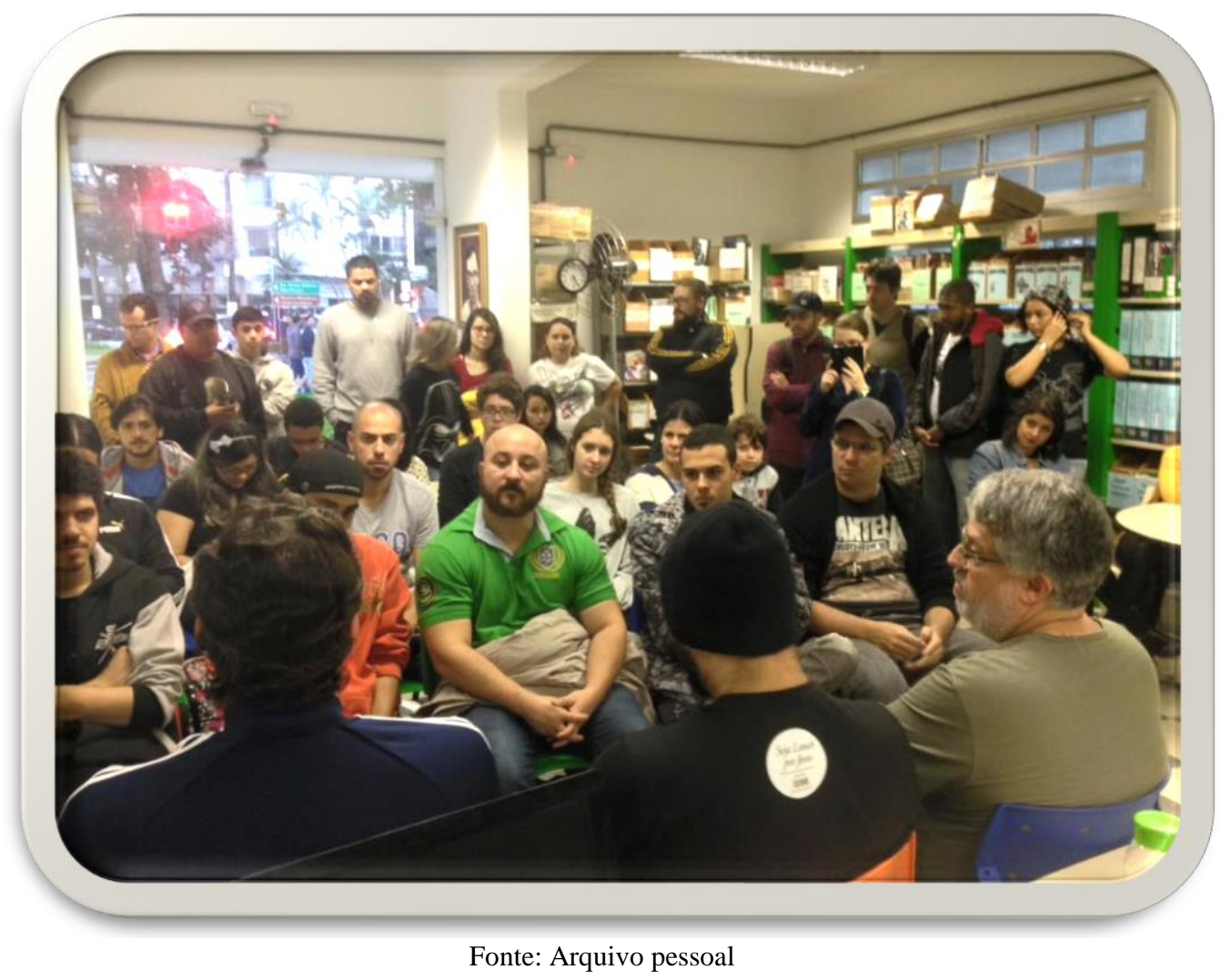

Os presentes fizeram muitas perguntas aos artistas, demonstrando que entre eles havia não só leitores de quadrinhos, mas também potenciais quadrinistas com interesse em aprender mais sobre os requisitos necessários para conseguir projeção internacional com seus trabalhos. Tais informações não costumam ser oferecidas em outros ambientes se não nos que são dedicados à publicação e circulação de histórias em quadrinhos.

Os bate-papos também podem fomentar a discussão sobre temas políticos ou ideológicos, como ocorreu em 28 de agosto de 2016, quando pesquisadores foram convidados a debater sobre os limites do humor frente ao atentado sofrido pelos cartunistas do jornal francês Charlie Hebdo, em janeiro de 2015, e no dia 27 de abril de 2015, quando os cartunistas Osvaldo da Costa, Fausto Bergocce e Geandré, expuseram suas 
considerações sobre o papel do humor gráfico na época da ditadura militar no Brasil e a importância de publicações alternativas como o jornal Ovelha Negra ${ }^{53}$.

As reflexões em torno dos limites do humor e terrorismo renderam uma exposição virtual promovida pela Gibiteca de Santos em sua página do Facebook, cujo tema era o atentado terrorista contra o jornal francês Charlie Hebdo em janeiro de 2015. Assim, os temas foram abordados em diferentes datas e sob diferentes perspectivas, propiciando que frequentadores da Gibiteca pudessem aprofundar seu conhecimento sobre determinados assuntos, além de aumentar seu repertório e visão crítica por meio da interação promovida nos vários eventos.

No dia 12 de outubro é comemorado, por alguns fanzineiros, o dia nacional do fanzine. A data, celebrada desde 2012 na Gibiteca de Santos, por iniciativa do fanzineiro e pesquisador Gazy Andraus, marca o lançamento do fanzine Ficção, de Edson Rontani, ocorrido no ano de 1965, considerado por alguns estudiosos o primeiro fanzine brasileiro ${ }^{54}$.

Os eventos promovidos pela Gibiteca de Santos juntamente com produtores de fanzines, como Thina Curtis, responsável pelo projeto Fanzinada, que visa levar os fanzines às escolas e comunidades carentes, fazem parte de uma ação idealizada por Edson Rontani Filho para que a data seja registrada oficialmente no calendário nacional e que está em trâmite na cidade de Piracicaba, cidade natal de Rontani ${ }^{55}$. Todos os anos, além de palestras e exposições de fanzines, também são realizadas atividades e oficinas para que os participantes confeccionem seus próprios fanzines. (Figura 16)

\footnotetext{
${ }^{53}$ http://quadro-a-quadro.blog.br/lancamento-de-uns-e-outros-e-bate-papo-sobre-o-ovelha-negra/

${ }^{54} \mathrm{http}$ ://impulsohq.com/artigos/consciencia-e-quadrinhos/dia-nacional-do-fanzine-e-a-importancia-derontani/

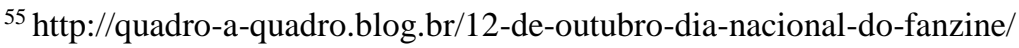


Figura 16 - Exposição de fanzines realizado na Gibiteca em 12/12/2015

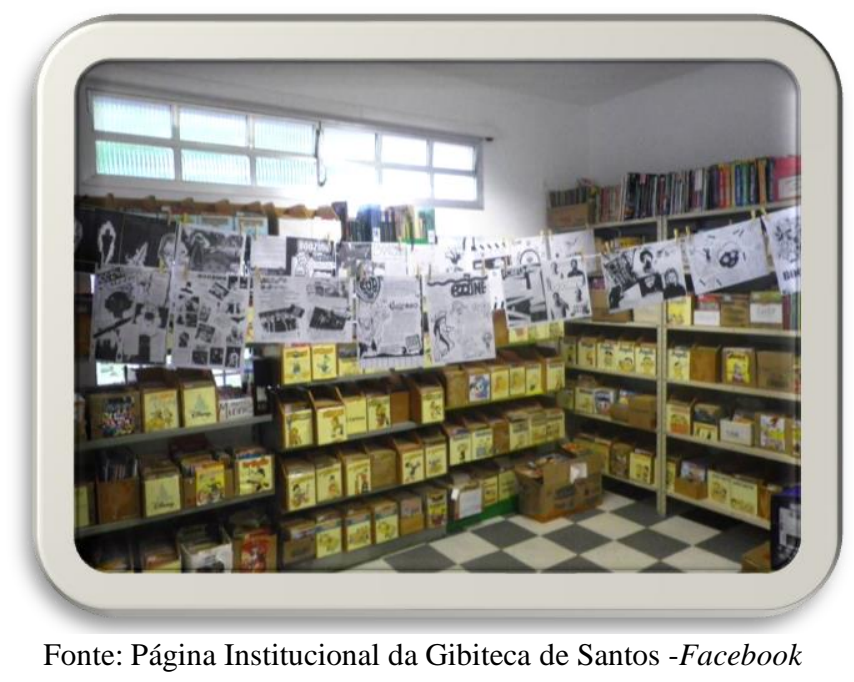

Peruzzo (2000) associa o engajamento social ao exercício da cidadania, uma vez que por meio do envolvimento em atividades concretas os indivíduos constroem não só o conhecimento, mas também novas relações de sociabilidade mediadas pelo próprio ambiente.

Ou seja, ao organizar diversos tipos de atividades, a Gibiteca não só favorece que um número cada vez maior de pessoas tenha acesso às revistas em quadrinhos, como também desempenha um papel social de agregador de indivíduos cujos interesses em comum os leva a trocar experiências sobre seus personagens favoritos em um ambiente acolhedor.

\subsubsection{Produção de quadrinhos institucionais}

Tendo em vista o potencial dos quadrinhos na apreensão de certos conteúdos, formatos como cartilhas e folders costumam ser usados não só por empresas, como também organizações e órgãos públicos de saúde ou Comunicação, no intuito de informar e auxiliar no processo de conscientização da população sobre diversos temas (TAKAHASHI, 2015).

Pensando nisso, a prefeitura municipal de Santos, por meio da Secretaria de Comunicação e Resultados e da Gibiteca, viabilizou o lançamento da história em quadrinhos Receptação é Crime, em novembro de 2016. A publicação integra uma série de ações de conscientização para evitar a compra de materiais suspeitos e a campanha foi organizada por Paulo Oshiro, responsável pelo projeto Luan Vive. 
Paulo Oshiro, perdeu o filho de 18 anos em uma tentativa de assalto em uma avenida movimentada de Santos no final de 2015. Luan foi surpreendido por dois assaltantes que queriam levar seu celular.

O lançamento da história em quadrinhos Receptação é Crime ${ }^{56}$, que ocorreu na Gibiteca no dia 19 de novembro de 2016, também contou com uma exposição com as artes usadas no folder. Paulo Oshiro proferiu uma palestra sobre a importância de conscientizar os jovens quanto à compra de celulares e aparelhos digitais sem saber sua procedência, pois os crimes só ocorrem porque existem pessoas dispostas a comprar estes aparelhos.

Com arte de Clayton Inloco, o argumento de Fábio Tatsubô e produção gráfica de Rodrigo Vieira (Figura 17), a publicação visa alertar crianças e adultos sobre os riscos de comprar mercadorias de procedência incerta. Sete mil exemplares foram distribuídos nas escolas municipais, onde também aconteceram palestras.

Ou seja, este tipo de ação, onde os participantes expõem seus problemas e compartilham experiências em comum, corroboram o ponto de vista de Maia (2012, p.24), ao afirmar que "os méritos da argumentação informal, das narrativas e dos testemunhos são vários, uma vez que podem contribuir para a ampliação do escopo da discussão".

Nestes eventos, o locutor cria uma conexão com os convidados e participantes de maneira que haja uma troca de informações entre os envolvidos. Segundo Signates (2003) Walter Benjamim foi um dos pioneiros a teorizar a mediação como uma forma fundamental "que permite pensar a relação da transformação nas condições de produção com as mudanças no espaço da cultura" (SIGNATES, 2003, p.38). Portanto, os eventos presenciais culturais "ajudariam a articular sentimento de injustiça e a expressar auto compreensão de opressão, humilhação ou exploração, vivenciada no contexto cotidiano (MAIA, 2012, p. 24)".

\footnotetext{
${ }^{56} \mathrm{http} / / / \mathrm{www} \cdot$ santos.sp.gov.br/?q=noticia/894796/projeto-luann-vive-realiza-exposi-o-do-hq-recepta-ocrime-na-gibiteca
} 
Figura 17 - Capa da história em quadrinhos Receptação é crime

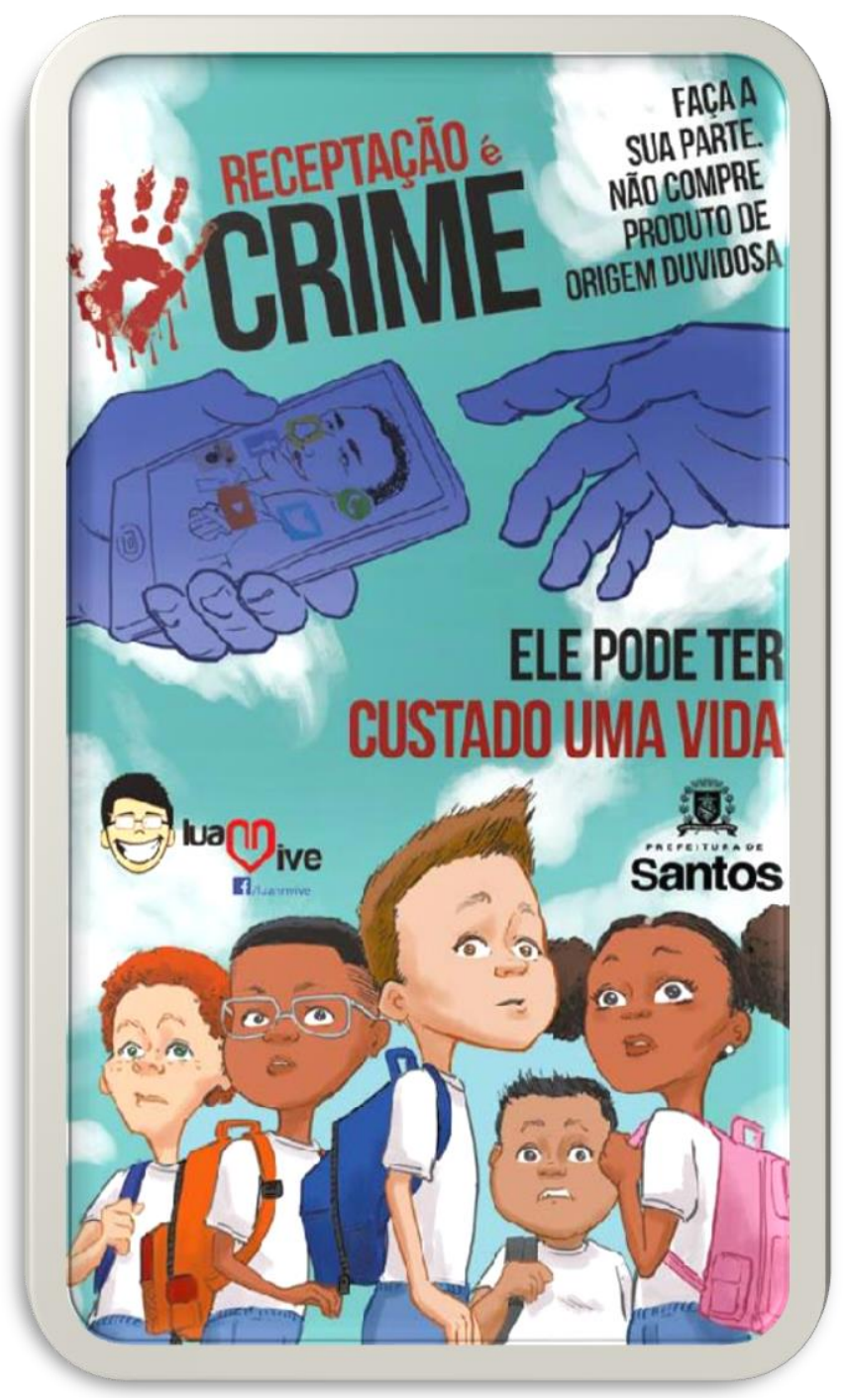

Fonte:http://impulsohq.com/agenda

Assim, é possível observar que um evento ocorrido em torno de uma história em quadrinhos na Gibiteca carrega, em sua constituição, as características que comprovam sua eficácia como uma forma de levar conhecimento a um determinado público por meio de uma mídia bem específica, que está inserida em uma cultura cujos próprios elementos constitutivos são pertinentes somente a ela, bem como mencionado por Pustz (2000).

Em entrevista concedida ao site Universo $H Q^{57}$, o artista baiano Antônio Cedraz afirmou que a revistas em quadrinhos institucionais atingem um universo bem heterogêneo de pessoas, de uma forma simples, agradável e divertida, sem perder a seriedade dos

\footnotetext{
${ }^{57} \mathrm{http}: / /$ www.universohq.com/materias/empresas-no-brasil-investem-em-quadrinhos-para-funcionarios-eclientes/
} 
assuntos abordados. De acordo com o autor da Turma do Xaxado, os quadrinhos potencializam a assimilação da informação e atraem muito mais do que um folder ou um informativo só com textos, pois oferecem entretenimento aos leitores.

\subsubsection{Baú da gibiteca}

Realizado desde 2015, o Baú da Gibiteca é uma ação que doa revistas de histórias em quadrinhos a escolas da periferia da cidade (Figura 18). Desde o início de sua realização até dezembro de 2016, foram doadas cerca de 4.700 revistas em 19 baús com média 250 revistas cada, que são enviados às escolas municipais com o intuito de integrar suas gibitecas ou bibliotecas.

A seleção das revistas doadas é feita pelos funcionários da Gibiteca, que separam exemplares repetidos do acervo principal e quando acumulados o suficiente para encher o baú, são enviados às escolas. Embora não haja um acompanhamento formal do que é feito com as revistas nas escolas, no momento de seu recebimento, alunos e professores estão presentes, registrando que há um volume de revistas à disposição dos alunos nas bibliotecas. Eventualmente, alunos e professores contatam a Gibiteca para agradecer e informar que os quadrinhos estão sendo utilizados, porém, de acordo com relatos de pedagogos que frequentam eventos da Gibiteca, raramente são realizadas atividades que usem os quadrinhos em sala de aula como uma atividade pedagógica. A estudante de Pedagogia da Universidade Santa Cecília, Daniela Resende, afirma que os alunos são apenas direcionados às bibliotecas para que manuseiem e leiam as revistas, sem qualquer acompanhamento didático ${ }^{58}$.

Para Nogueira (2017, p. 104), “a gibiteca escolar aproxima o aluno da escola e o aluno de si mesmo. Desenvolve habilidades que vão desde a organização de ideias à elaboração de respostas para desafios propostos por tarefas aparentemente inocentes".

\footnotetext{
${ }^{58}$ Daniela é frequentadora da Gibiteca e compartilhou suas considerações sobre o uso dos quadrinhos em sala de aula durante a realização de uma palestra sobre o tema, realizada na terceira edição da Santos Comic Expo, em outubro de 2015.
} 
Figura 18 - Um dos baús doados às escolas

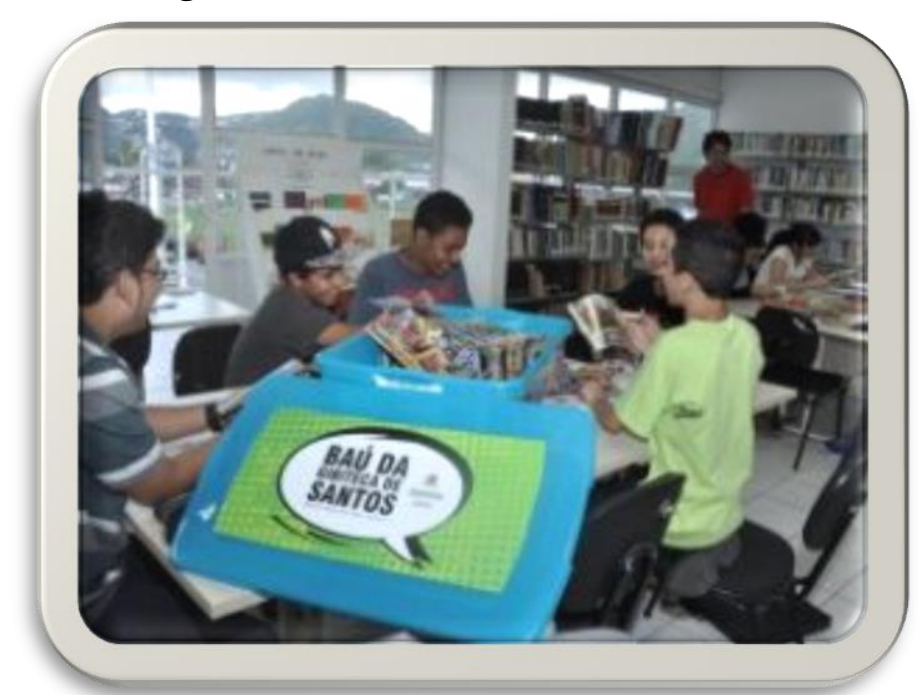

Fonte: Página Institucional da Gibiteca de Santos - Facebook

\subsubsection{Feira de trocas}

Agendada normalmente nos feriados, a Feira de Trocas (Figura 19) é uma ação que disponibiliza revistas em quadrinhos repetidas do acervo da Gibiteca para a troca entre seus frequentadores. A cada revista doada, o leitor pode levar outra que esteja disponível em uma das caixas, separadas exclusivamente para este fim.

Crianças acompanhadas por seus pais e alguns adultos costumam trocar seus quadrinhos, que são, em sua maioria, da Turma da Mônica e de personagens Disney. No entanto, não é preciso esperar a realização de uma feira de trocas, pois as caixas ficam disponíveis para que qualquer pessoa possa trocar uma revista em qualquer dia, mas o maior volume de interessados é observado os domingos de manhã, quando os santistas aproveitam o fechamento da avenida da praia para os carros, para passear com seus filhos e animais de estimação, e muitos deles levam então seus quadrinhos para serem trocados. A diferença entre os dias de expediente normal e a feira, é que a feira tem ampla divulgação na mídia e incentiva os colecionadores da região a comparecerem à Gibiteca ou a algum outro lugar estipulado, garantindo que a quantidade de opções de quadrinhos seja maior e que os leitores e colecionadores realizem as trocas entre si também.

Dificilmente um leitor irá completar uma coleção a partir do que está disponível nessas caixas. O que é observado por quem frequenta o local, é que os pais costumam incentivar seus filhos ou avós estimulam seus netos, grande parte na faixa etária entre os 7 e 10 anos de idade, a que continuem lendo outras histórias além das que possuem, levando para casa uma revista diferente. 
Figura 19 - Caixas com quadrinhos repetidos para troca - 24/07/2016

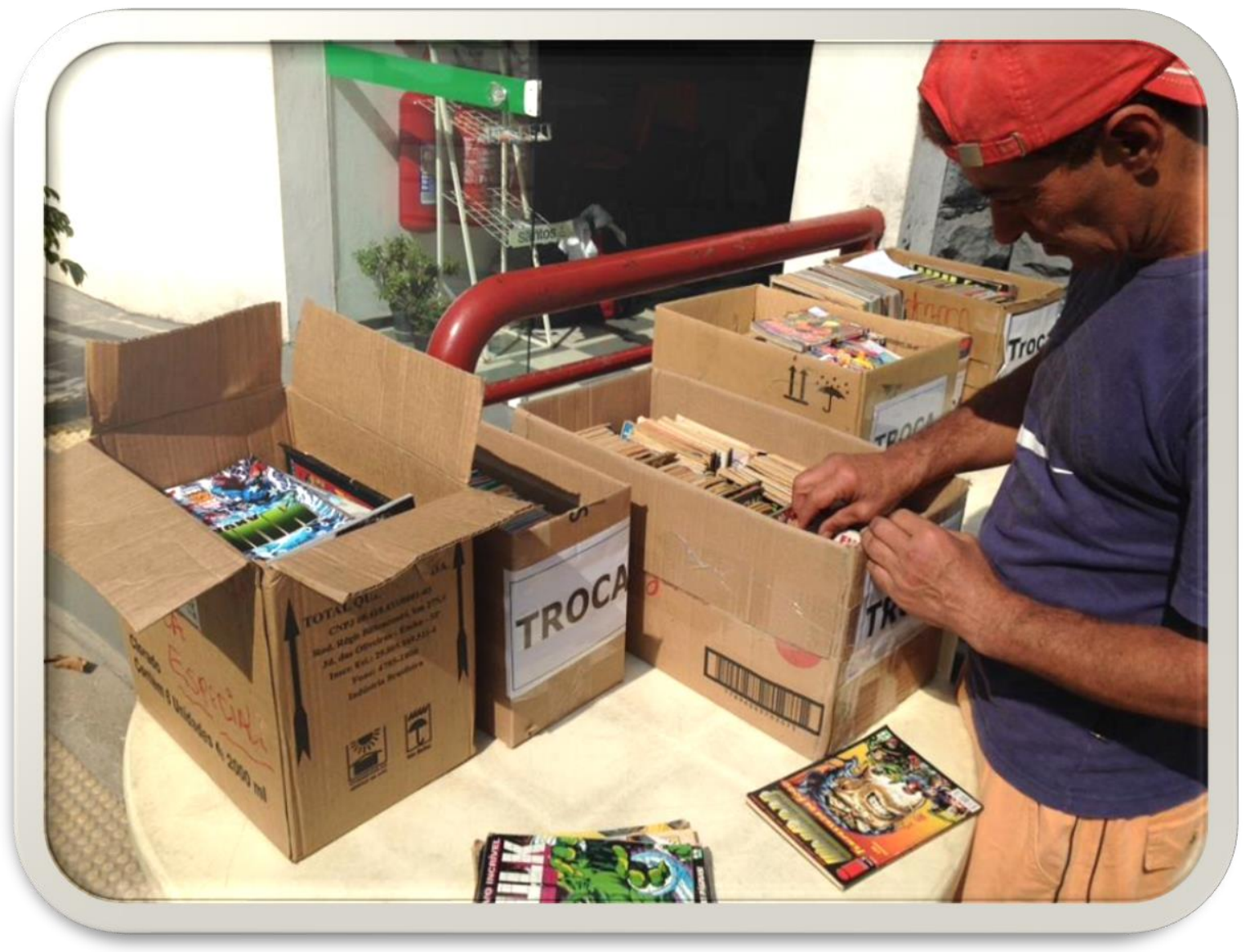

Fonte: Página institucional da Gibiteca de Santos - Facebook

\subsubsection{Doações recebidas}

Como o acervo hoje depende exclusivamente de doações recebidas, moradores da região, artistas, editores ou mesmo outras gibitecas, enviam contribuições para a Gibiteca de Santos. Estas doações são tombadas, fotografadas e divulgadas na página da Gibiteca no Facebook.

O primeiro acervo da Gibiteca foi doado pela mãe de Marcel Rodrigues Paes, após sua morte, com cerca de 1.500 revistas. A partir de então, a constituição de coleções de mais variados temas e estilos de quadrinhos continuam chegando semanalmente, fazendo com que em um ano de funcionamento, seu acervo tenha passado para cerca de 4.000 exemplares. Seja via colecionadores (Figura 20), seja via autores que enviam seus lançamentos, cada item recebe uma numeração de tombamento. Muitos volumes se amontoam na área da copa da gibiteca, em pilhas e caixas, sem o devido cuidado muitas 
vezes dispensados aos livros em bibliotecas. Por isso, ainda que exista um catálogo do que é tombado em uma planilha de Excel, o acúmulo de revistas e a falta de espaço para acomodá-las dificulta a contagem real da quantidade de títulos disponíveis no local.

Figura 20- Matéria publicada no jornal A Tribuna em dezembro de 1993

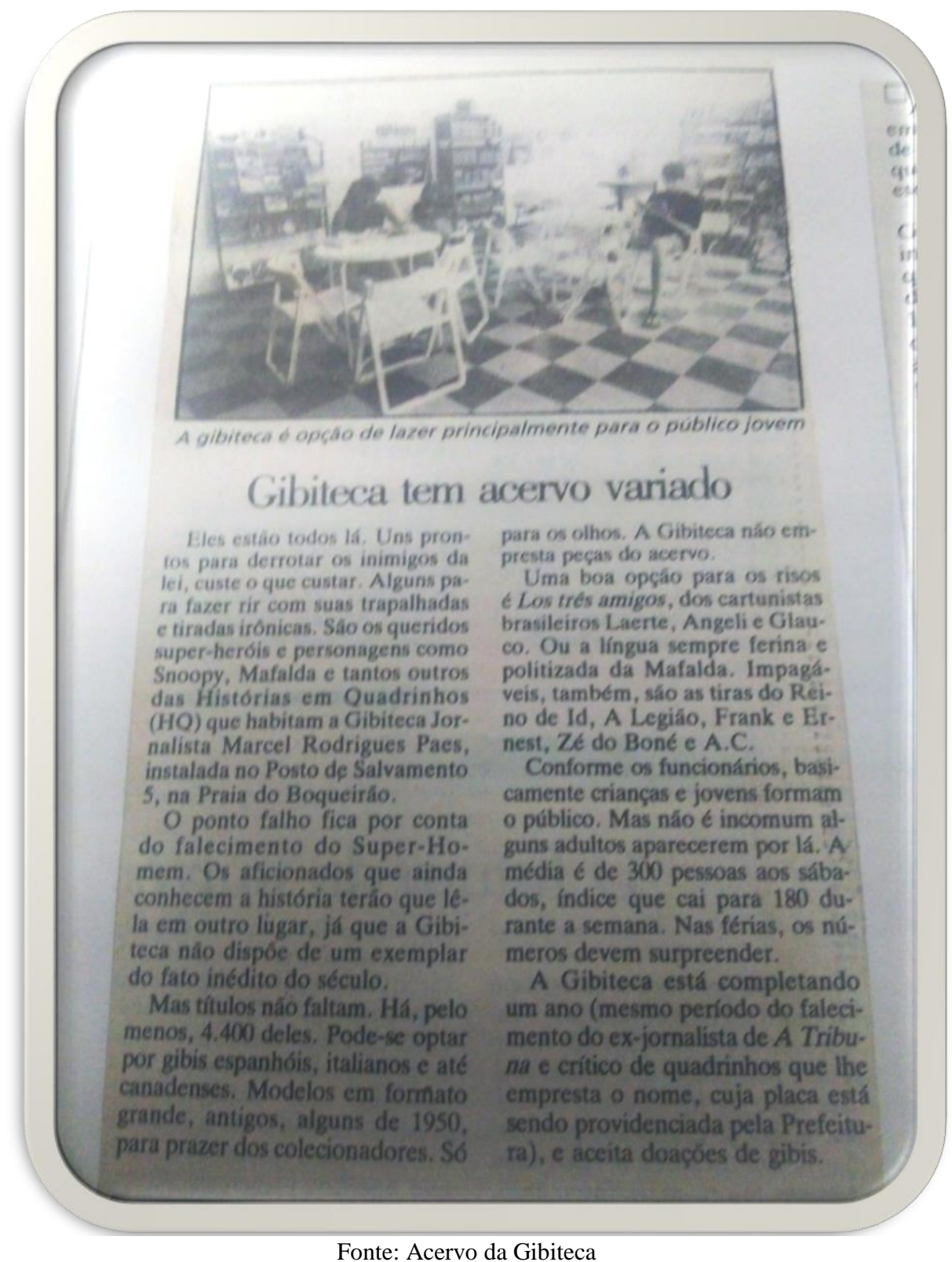

Em 2017, por exemplo, o quadrinista R.B. Silva doou cerca de 4.000 quadrinhos de sua coleção particular à Gibiteca de Santos ${ }^{59}$. Todos em inglês, arcos completos de superheróis. As aplicações dessas revistas em disciplinas de artes e língua inglesa seriam

\footnotetext{
${ }^{59}$ https://www.gluseum.com/BR/Santos/916981655082815/Gibiteca-de-Santos---Gibiteca-MunicipalMarcel-Rodrigues-Paes
} 
inúmeras, caso elas estivessem disponibilizadas ao público. Devido à falta de espaço e de catalogação, apenas alguns frequentadores assíduos têm conhecimento desses exemplares e os solicitam para leitura.

Também em 2017, a Gibiteca recebeu um exemplar da graphic novel Angola Janga (Figura 21), de Marcelo D’Salete. A importância da aquisição de títulos como Angola Janga reside no fato de que, além do fator econômico referente ao custo desse tipo de publicação - R \$89,00 na livraria Saraiva, em maio/2018 -, que torna inviável a compra tanto por parte de algumas instituições como por parte principalmente do público, está em seu enredo de grande valor histórico e pedagógico: a história narra a trajetória de Zumbi e do mais importante quilombo brasileiro, o quilombo dos Palmares. Publicada pela editora Veneta em 2017, a pesquisa de Marcelo resultou em 432 páginas que ilustram a resistência dos negros no Brasil, em uma época em que assuntos ligados à representatividade das minorias nunca esteve tão em voga.

Figura 21 - Graphic Novel Angola Janga

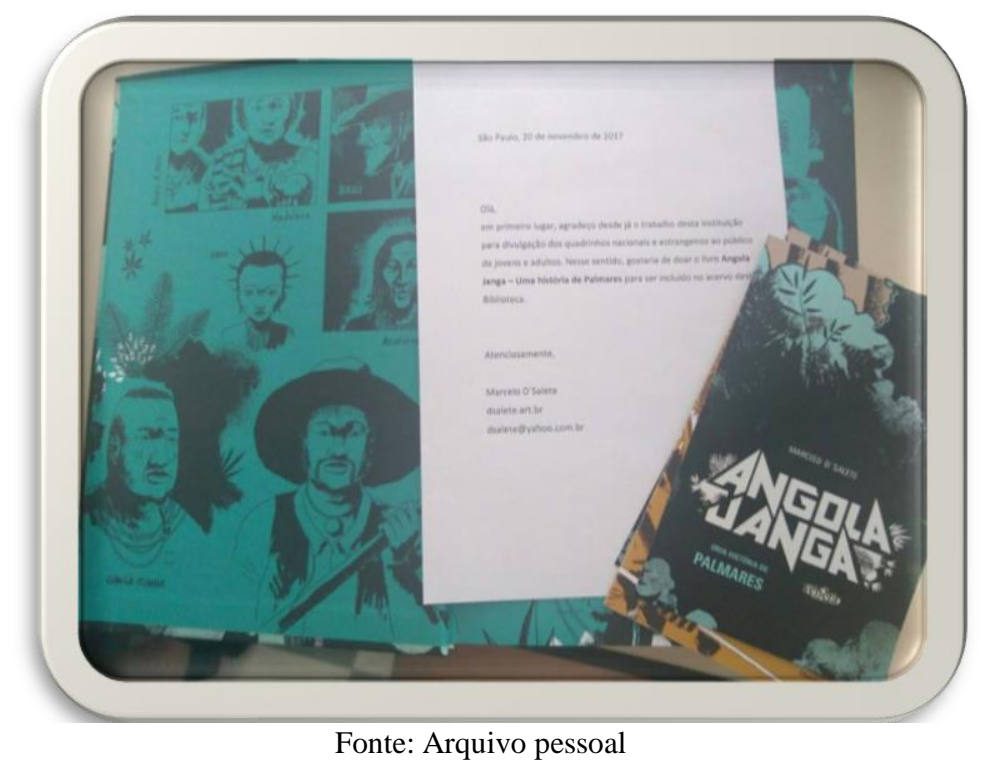

\subsubsection{Visitas monitoradas}

São visitas realizadas por alunos de escolas municipais ou privadas, centros de assistência a deficientes (Figura 22) ou idosos, agendadas previamente. Os alunos são acompanhados por professores e podem consultar revistas que são lidas no local e, de 
acordo com a lista de agendamentos da Gibiteca, foram realizadas 53 visitas entre 2013 e 2016.

A importância do acesso à cultura por parte dos deficientes auditivos, por exemplo, vai além da do entretenimento que pode representar um passeio a um equipamento localizado na praia: Em pesquisa realizada na Universidade Federal de Sergipe, sob orientação de Valéria Bari, Rebeca Oliveira (2017), demonstrou que o acesso às histórias em quadrinhos pode se tornar uma forma de mediação entre os alunos deficientes auditivos e as obras de literatura brasileira.

Agendadas por telefone, o objetivo das visitas à Gibiteca de Santos é oferecer ao público contato com o universo das histórias em quadrinhos, porém, assim como acontece nas escolas que recebem o Baú da Gibiteca, normalmente não há a realização de uma atividade pedagógica ou reflexão sobre o que os visitantes leem. Eles apenas circulam pelo local e escolhem o que querem ler, enquanto o funcionário observa passivamente.

Figura 22 - Visita de pessoas assistidas pelo centro de referência de saúde auditiva - 20/07/2016

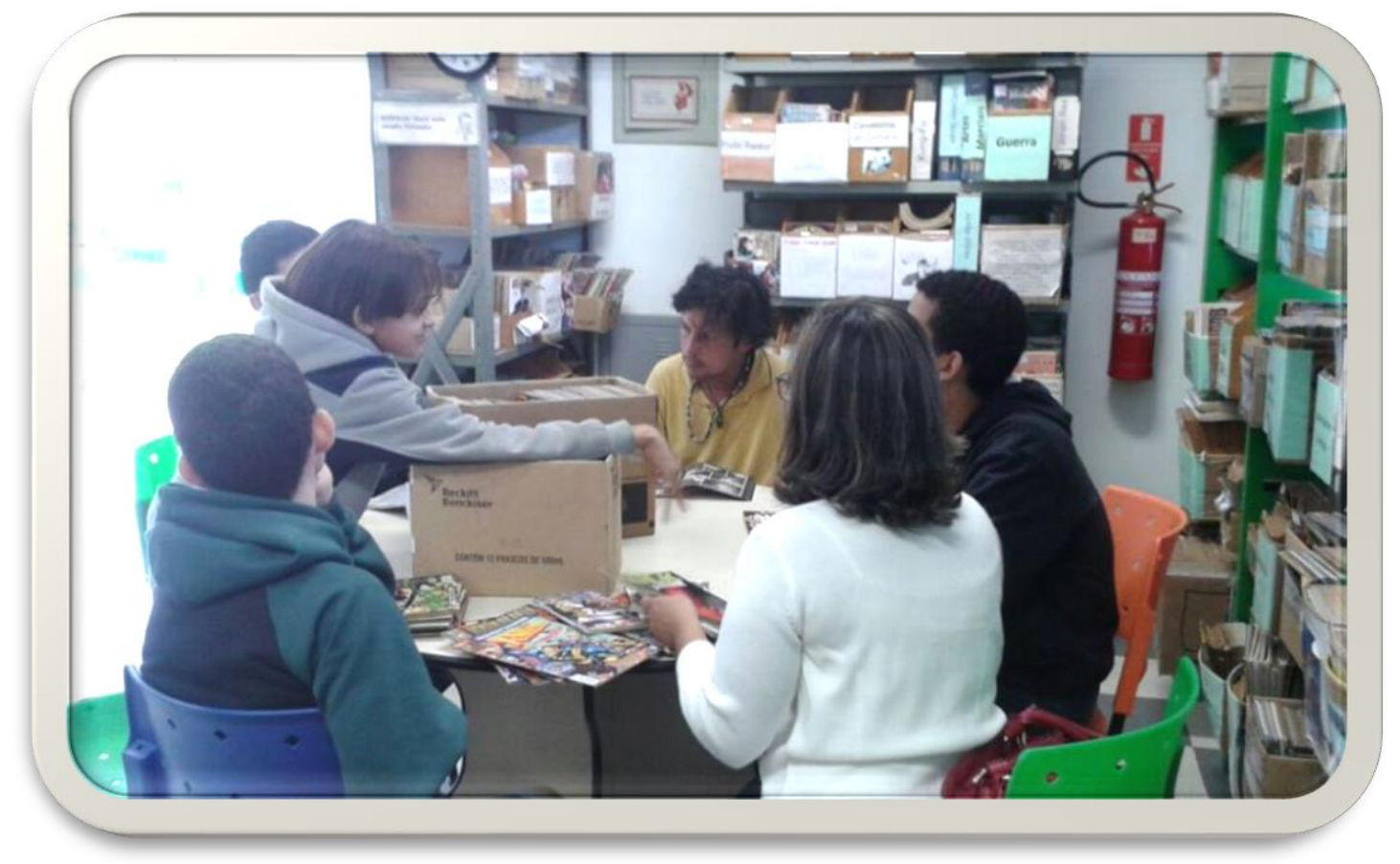

Fonte: Página Institucional da Gibiteca no Facebook 


\subsubsection{Oficinas e cursos}

Os cursos e oficinas oferecidos pela Gibiteca variam entre técnicas de desenho, noções básicas de mangá, roteiro, confecção de fanzines, entre outros. Ministrados por artistas locais, os cursos são gratuitos e os participantes precisam se inscrever previamente.

Foram realizados 47 cursos e oficinas entre 2013 e 2016. Cursos de desenho, roteiro, ilustração, mangás... E, de acordo com as respostas enviadas no questionário online (Apêndice A), seus participantes puderam ampliar seu conhecimento e interesse sobre os quadrinhos, bem como conhecer melhor a carreira que gostariam de seguir, além de se sentirem motivados a continuar desenhando ou criando roteiros: "a gibiteca foi um dos impulsos e motivação em relação à minha profissão, por isso também entrei na faculdade e estou cursando Designer Gráfico” (Respondente 6, pergunta 9 - Apêndice A),

Artistas que atuam no mercado nacional e internacional de quadrinhos, como Fábio Yabu, autor da animação Princesas do Mar (Figura 23), e Fábio Coala ${ }^{60}$, quadrinista, frequentaram os cursos e atividade oferecidos pela Gibiteca e ressaltam sua importância para sua formação profissional:

Figura 23 - Depoimento de Fabio Yabu

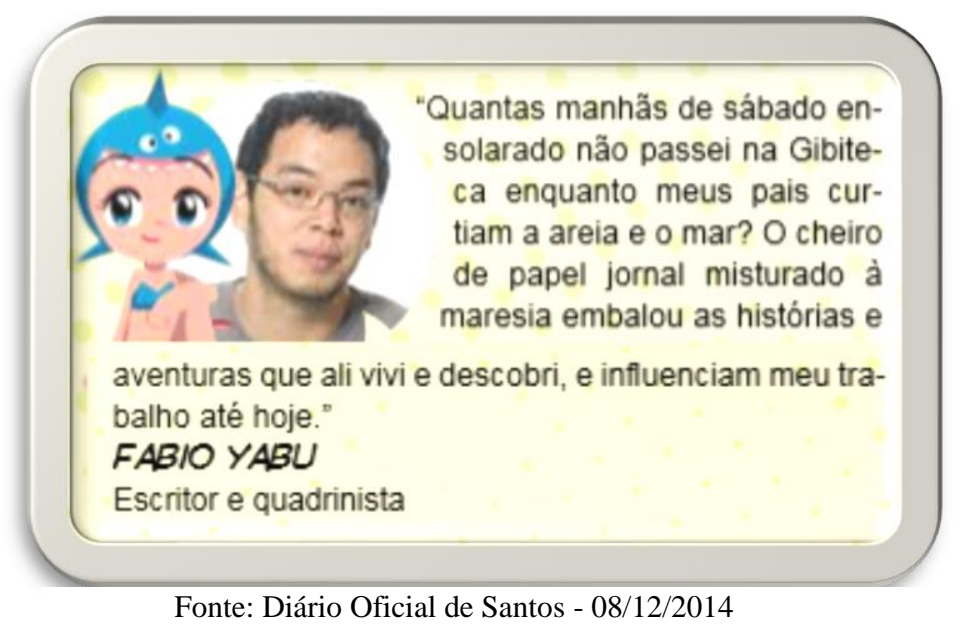

Para Sônia Luyten (DIÁRIO OFICIAL, 2014, p. 5), as oficinas e palestras promovidas pela Gibiteca são responsáveis pela formação de novos leitores e de novos profissionais na arte dos quadrinhos. Sua perspectiva é corroborada pelas afirmações de outros editores, pesquisadores e

\footnotetext{
${ }^{60} \mathrm{https}: / /$ www.youtube.com/watch?v=8I9y_1zD_1k
} 
artistas que forneceram seus depoimentos à edição especial do Diário Oficial de Santos, dedicado aos 22 anos de existência da Gibiteca, publicado em 08 de dezembro de 2014.

\subsubsection{Exposições}

As exposições que ocorrem na Gibiteca costumam abordar temas diversos, não necessariamente relacionados aos quadrinhos. Grande parte das exposições é constituída de trabalhos de artistas locais, mas o local já abrigou também artes enviadas de outros países, como África e Argentina.

A Associação de Quadrinistas e Cartunistas - AQC -, também já realizou diversas exposições com trabalhos de seus associados, bem como outras instituições, como a Escola Oficina - Escola de desenhos de Santos-, que enviam produções de seus alunos para serem expostas na Gibiteca. No período de 2013 a 2017, as exposições eram organizadas e idealizadas pelo coordenador Fábio Tatsubô, que entrava em contato com os artistas e cuidava da divulgação de cada evento.

Saúde Mental $^{61}$ e deficiência auditiva ${ }^{62}$ foram assuntos tratados em exposições e bate-papos que contaram com especialistas nessas áreas, como quando ocorreu no lançamento da exposição da deficiente auditiva, Larissa Medeiros, que teve a interpretação de uma intérprete de Libras durante o bate-papo promovido em 17 de dezembro de 2016, para o lançamento de sua exposição (Figuras 24 e 25).

Tais ações indicam que o potencial de espaços destinados ao entretenimento vai além de apresentar obras e produtos culturais, podendo representar lugares onde a acessibilidade à cultura seja discutida, promovendo assim, inserção social de pessoas que costumam ser excluídas de eventos e produções em geral.

Porém, o que ocorre com as exposições é que, ao menos que estejam vinculadas a alguma atividade como um bate-papo, sua abertura não costuma atrair visitantes à Gibiteca. Normalmente, além dos artistas responsáveis, apenas alguns parentes e amigos prestigiam seus trabalhos.

\footnotetext{
${ }^{61} \mathrm{http} / / / \mathrm{www} \cdot$ santos.sp.gov.br/?q=noticia/900844/gibiteca-recebe-bate-papo-e-exposi-o-de-hq-sobre-distrbios-mentais

${ }^{62} \mathrm{https} / / /$ www.juicysantos.com.br/vida-caicara/artistas-de-santos/vencendo-a-surdez-os-tracos-da-historiade-larissa-medeiros/
} 
Figura 24- Larissa Medeiros desenhando na Gibiteca no dia do lançamento de sua exposição

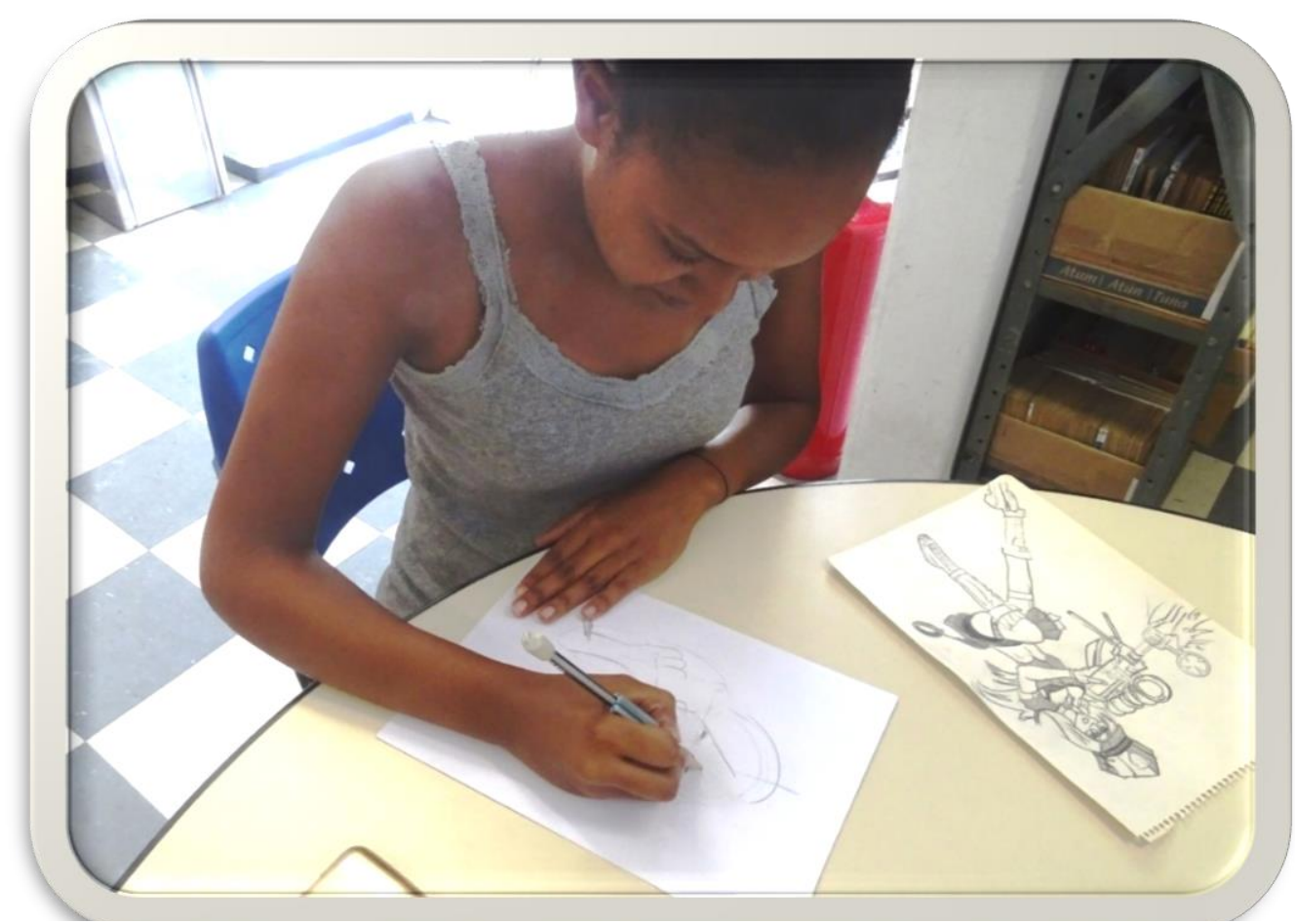

Fonte: https://www.juicysantos.com.br

Figura 25 - Larissa Medeiros diante de suas ilustrações em exposição

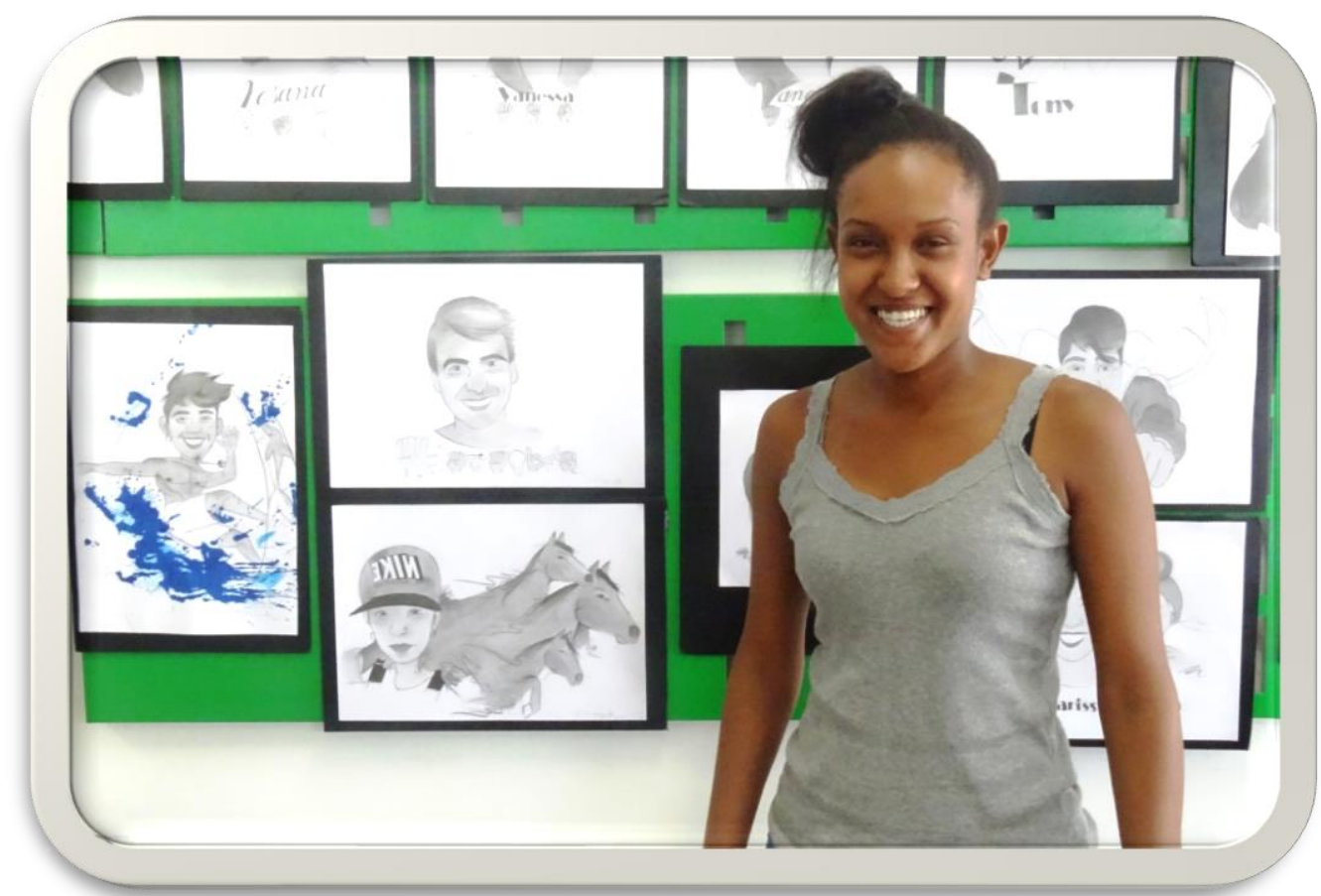

Fonte: https://www.juicysantos.com.br 


\subsection{Constituição física da gibiteca municipal de Santos e seus problemas}

A planta original do projeto da Gibiteca (Figura 26) pode ser encontrada no local, no arquivo com as matérias de jornal e outros documentos referentes à manutenção, coleção e rotina do lugar. Seus $59 \mathrm{~m}^{2}-5,40 \mathrm{~m}$ de largura x $11 \mathrm{~m}$ de comprimento-, abrigaram, inicialmente, pufes, carpetes de E.V.A (espuma vinílica acetinada) - e duas estantes para a coleção disponível em sua abertura. Foram disponibilizadas também cadeiras e mesas externas, porém, devido à falta de um guarda no local, não foi possível mantê-las.

Figura 26 - Planta do projeto da Gibiteca

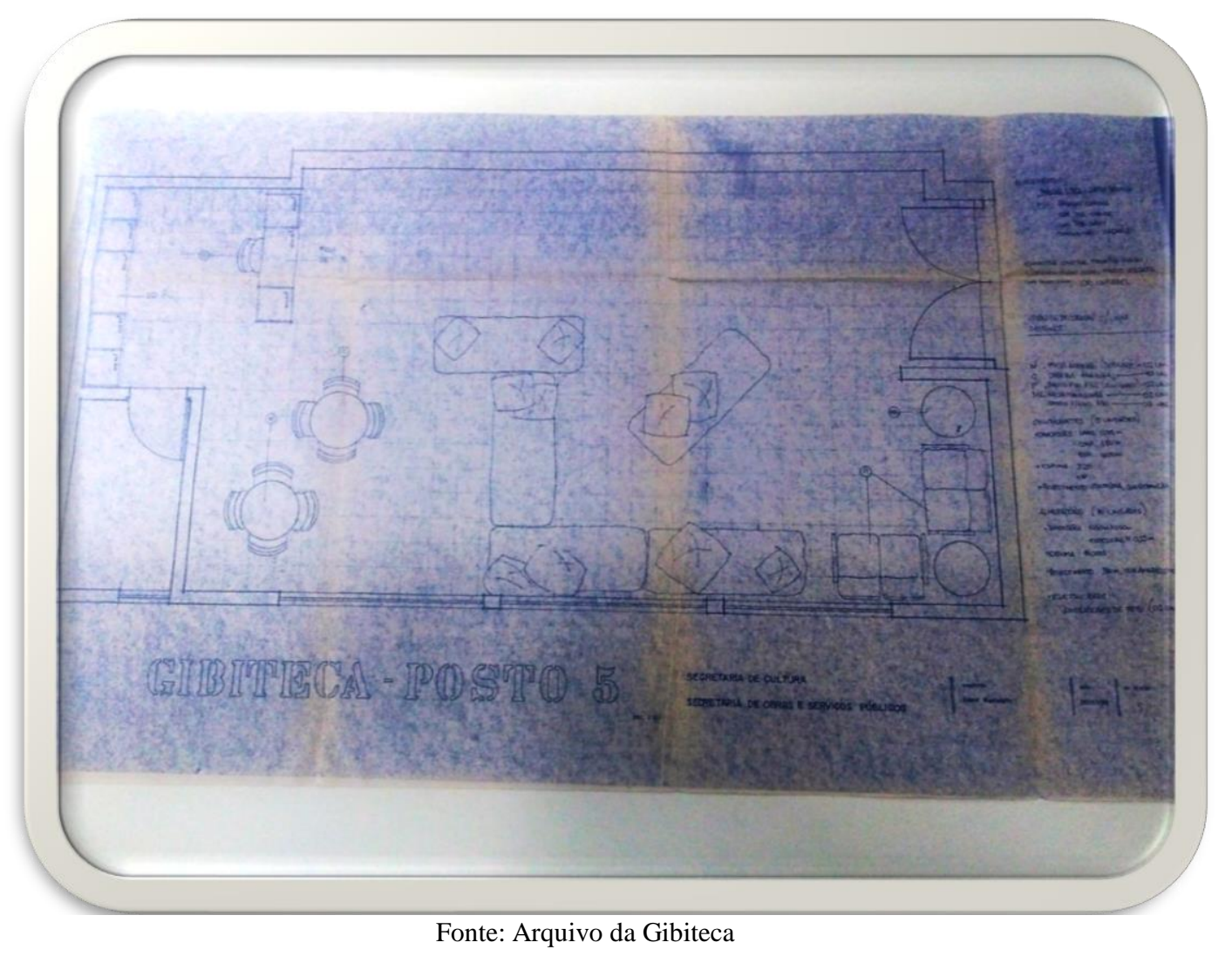

Com o aumento do acervo e a dificuldade da manutenção dos pufes, muitas vezes usados por moradores de rua para dormir, a decoração inicial foi então trocada pelas atuais mesas, cadeiras e estantes, que abrigam as caixas onde são acomodados os quadrinhos.

A falta de espaço para acomodar as doações, somada a outros problemas como falta de recursos para o pagamento de cachês de convidados e alta rotatividade de funcionários 
não especializados, exemplificam o descaso com que muitos equipamentos culturais são tratados no Brasil. Nesse sentido, comparar as práticas bem sucedidas de outros espaços dedicados à leitura de histórias em quadrinhos pode ilustrar que medidas poderiam ser tomadas pela Gibiteca de Santos no intuito de garantir melhores condições de armazenamento e manuseio dos materiais disponíveis; no caso de práticas não tão bem sucedidas, a comparação poderia corroborar a ideia de que as gibitecas não recebem a devida atenção dos órgãos públicos de maneira geral, e que por isso, a falta de manutenção e cuidados não seriam exclusivos da gibiteca Marcel Rodrigues Paes, mas um reflexo de um contexto nacional.

Na perspectiva de bibliotecários especializados em quadrinhos, como Scott (1991), o manuseio das revistas pelos funcionários de uma gibiteca exige cuidados específicos, por exemplo: sua retirada e devolução deve ser feita exclusivamente por eles, nunca pelos visitantes, pois tais itens mereceriam maior atenção do que a que é dispensada aos livros, uma vez que são muito mais frágeis.

Quanto à melhor forma de organizar as revistas, Scott menciona o Magafile (Figura 27): Inicialmente pensado para organizar revistas, o modelo foi adaptado pela Universidade de Michigan para guardar as edições seriadas de quadrinhos. Scott exemplifica que o rótulo pode indicar a numeração das revistas alocadas em cada caixa: PN6728.1 ao PN6728.6, lembrando que em caso de detalhamento das edições encontradas lá, a cada adição, o rótulo deverá ser trocado. Já em relação à Gibiteca de Santos, a organização das revistas se contrapõe às propostas de Scott (Figura 28). Sobre isso, não seria possível afirmar que se trata apenas de desconhecimento sobre as melhores formas de armazenamento do material, uma vez que em seu acervo a Gibiteca dispõe de diversos artigos e livros sobre biblioteconomia e confecção de acervo de quadrinhos. 
Figura 27 - Magafile como usado na Universidade de Michigan

\section{Popular Mechanics MAGAFIITS 8 SEPARATH INDFXES}

No more untidy shelves or magaxines stacked on top of each other.

POPULAR MECHANICS MAGAFILES will help you keep your magazines and bookshelves trim and orderly. PM is now offering a sturdy glossy lacquered Magafile to keep a year's supply of PM issues neatly together. The MAGAFILE stands alone with all twelve issues intact! Line them up by year on your bookshelf and always have a wealth of do-it-yourself information at your fingertips!

With every order you will receive FREE self-adhesive labels

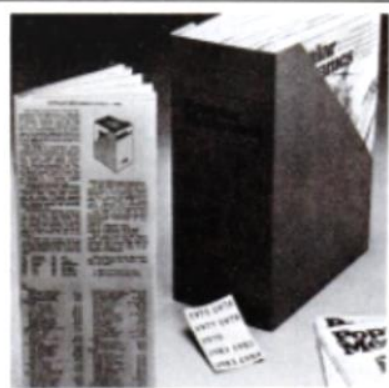

the year on the side that's convenient for you. Expose all the magazines on the shelf, or keep the solid side in view. It's your choice! Either way you'tl have a valuable, convenient
PM Indexes for the years $1975-1980$ are here!

Find the answers to your shop, home and car problems faster than ever.

Thousands of entries cross-reference the articles that have appeared in PM over these years.

Broad category listings help you locate articles on home remodeling. shop projects, solar energy, boats, photography, medicine, fuel conser vation, car maintenance and many other timely subjects:

ORDER BY YEAR! Price for each index is $\mathbf{3 2 . 2 5}$.

Fonte: Revista Popular Mechanics - Ago/81 - https://books.google.com.br/books

Figura 28 - Caixas organizadoras de revistas da Gibiteca de Santos

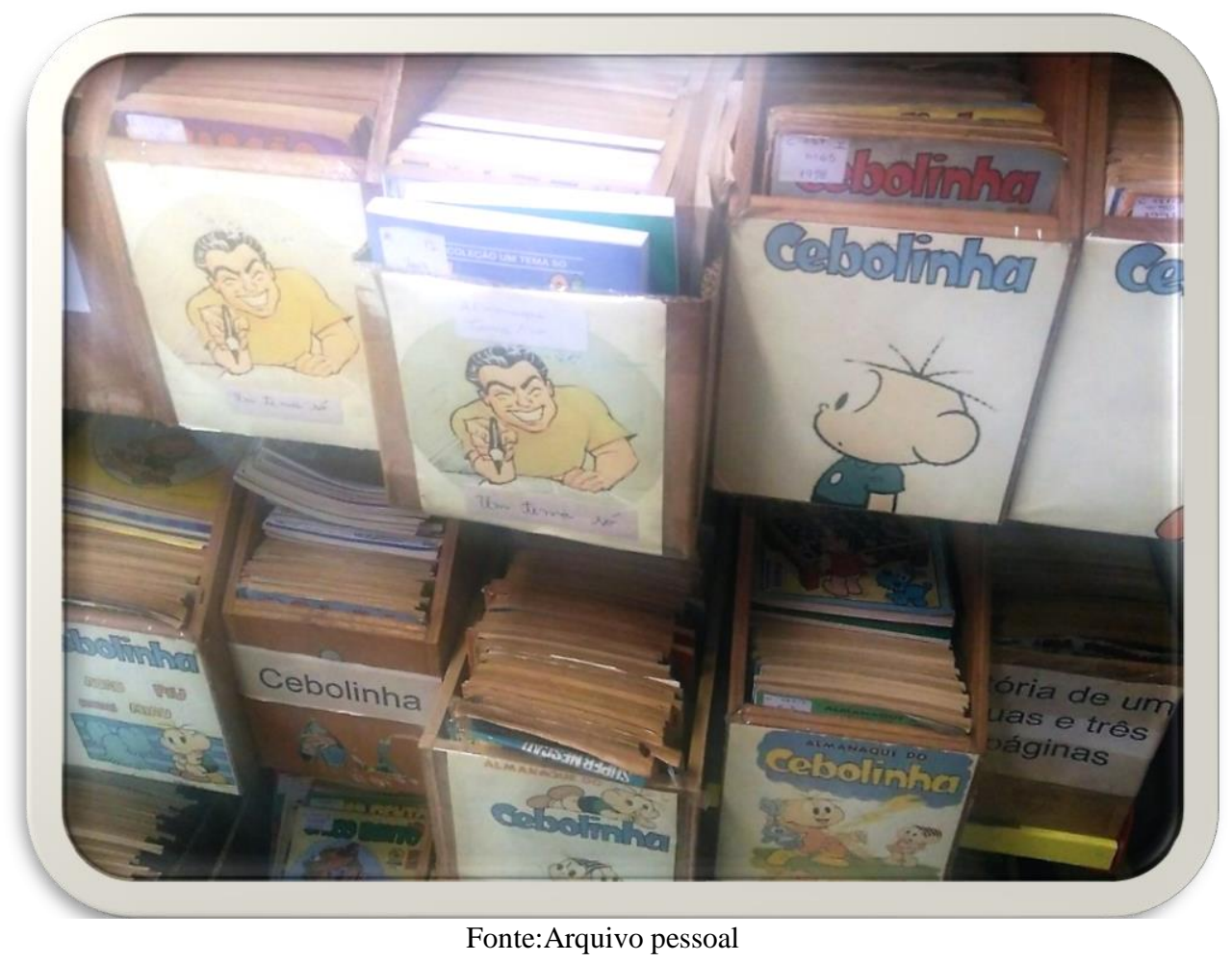

Em Belo Horizonte (figura 29 e 30), a opção encontrada pelo colecionador Antonio Gobbo foi encadernar as edições soltas depois que um arco estava completo, bem como 
ocorre com alguns títulos que estão na Gibiteca de Santos, mas que não estão disponíveis para consulta do público devido à fragilidade do material. Para Hugo Abud ${ }^{63}$, coordenador da Gibiteca Henfil, a encadernação dos exemplares soltos é a melhor opção para a manutenção de um material que se deteriora rapidamente (Figuras 31 e 32), no entanto, tal qual ocorre na Gibiteca de Santos, não há verba disponível para isso.

Figura 29 - Encadernados de Antonio Gobbo

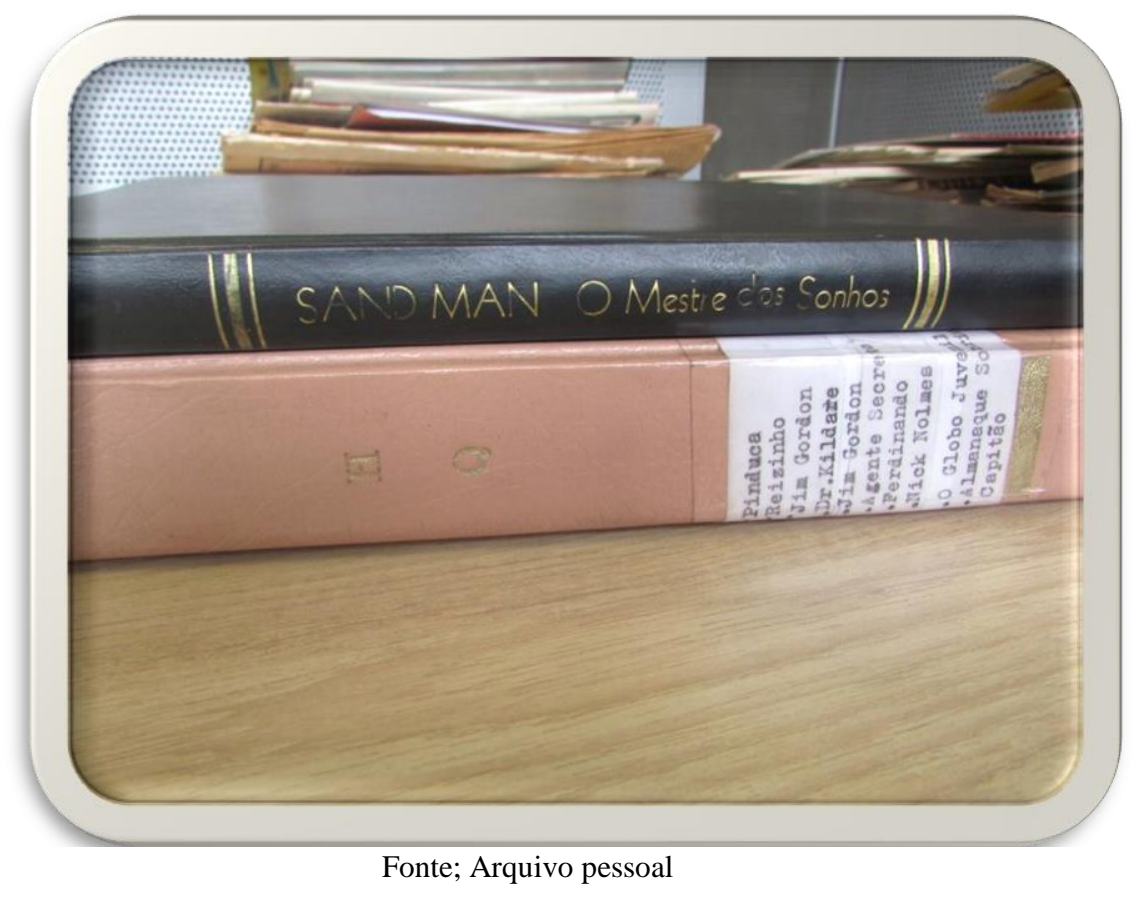

Figura 30 - Encadernados de Antonio Gobbo

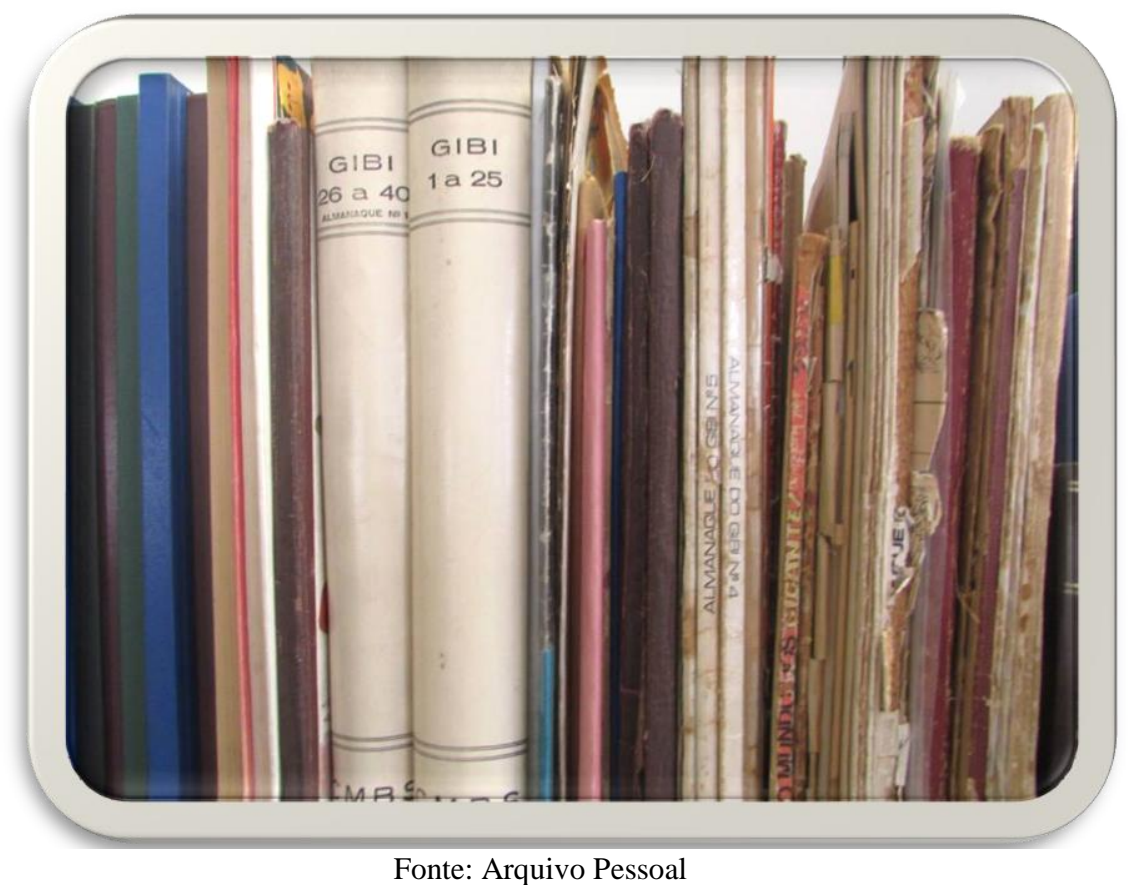

${ }^{63}$ Afirmação feita em visita presencial ao acervo da Gibiteca Henfil em 24 de maio de 2018. 
Figura 31 - Revistas do Superman em deterioração

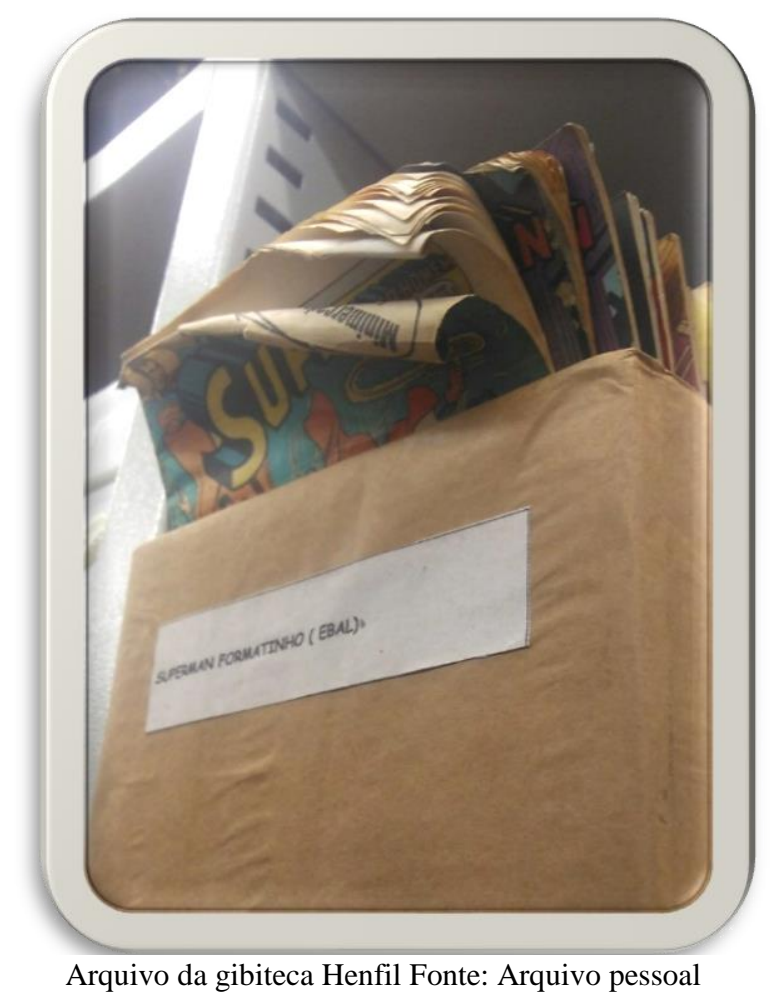

Figura 32 - Última edição da revista Gibi

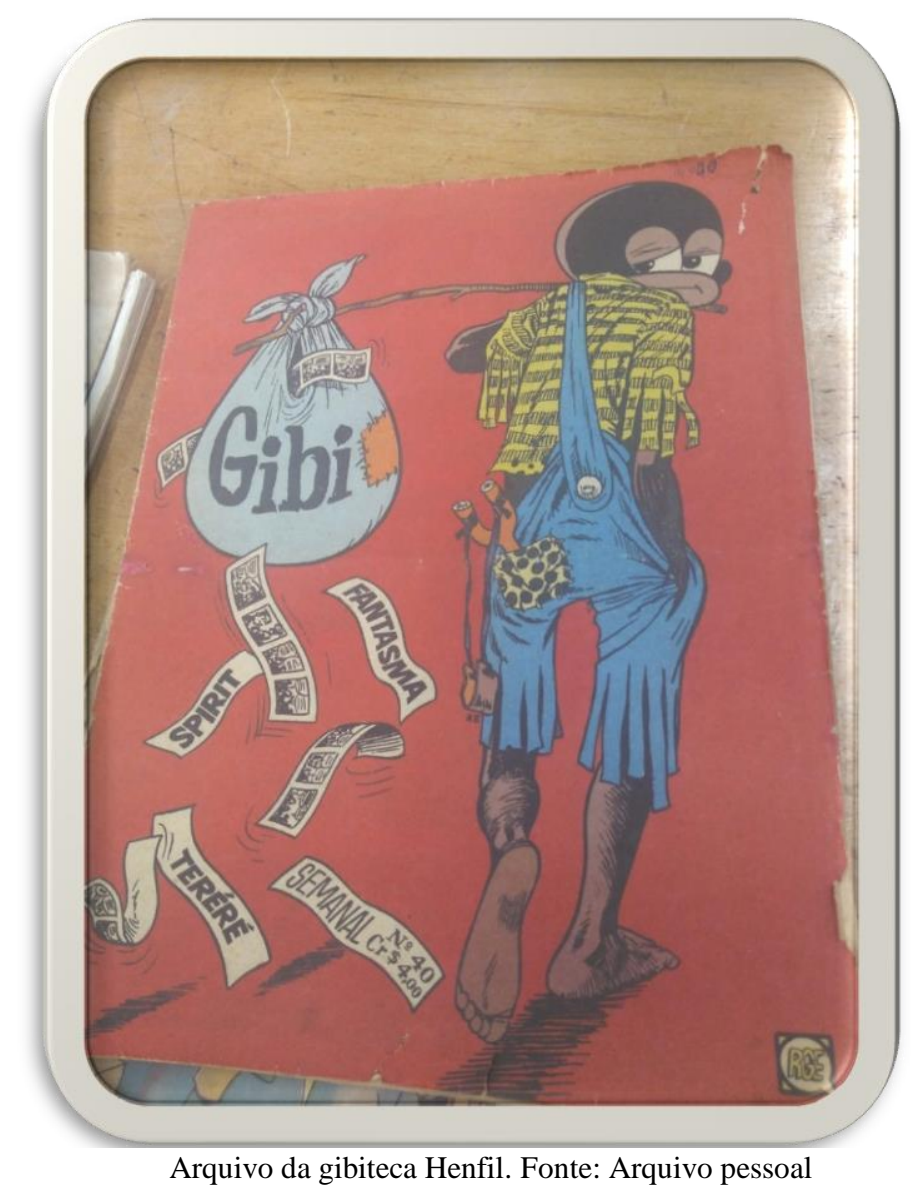

Arquivo da gibiteca Henfil. Fonte: Arquivo pessoal 
Em termos bibliográficos, quadrinhos são mais complicados que a maioria dos itens de entretenimento (SCOTT, 1991, p.59), por isso, apenas as publicações em formato de livro têm uma história mais longa de presença nas bibliotecas. No caso da Gibiteca de Santos, por exemplo, há uma estante própria para os quadrinhos publicados em livro e para os livros acadêmicos que são doados por pesquisadores de todo o Brasil (Figura 33).

Figura 33 - Livros acadêmicos na Gibiteca de Santos

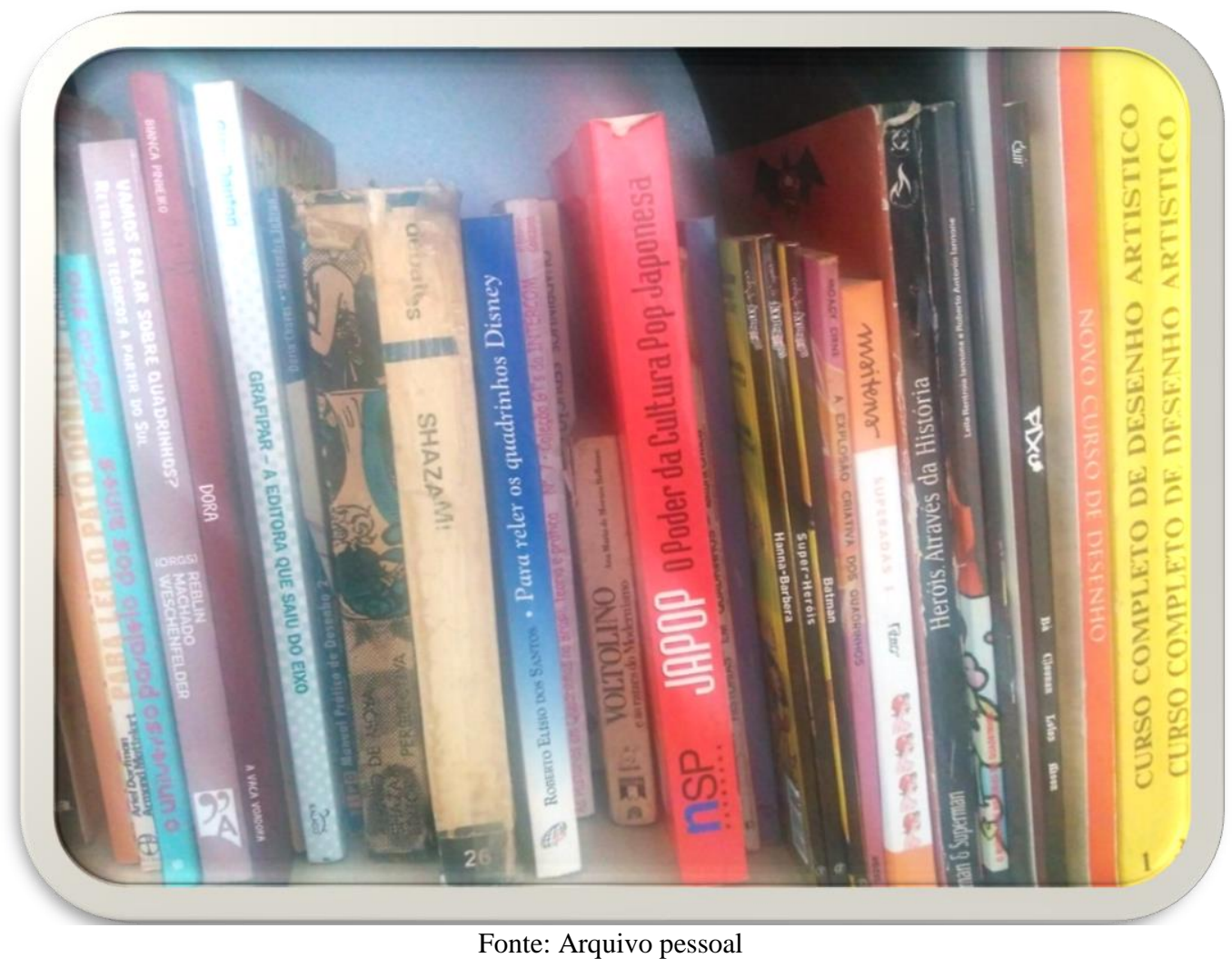

Apesar de quadrinhos possuírem números específicos quanto às suas séries, Scott (1991, p.64) explica que nos Estados Unidos há índices que facilitam sua identificação para uma catalogação bibliográfica. Já na Gibiteca de Santos, os itens recebidos são tombados e cadastrados em uma planilha de Excel, onde é inserida a localização de determinada revista nas caixas disponíveis nas estantes.

Há outros fatores que dificultam a conscientização por parte dos responsáveis das bibliotecas de quadrinhos quanto à sua aquisição: alguns títulos de coleções incompletas se tornam itens de colecionadores, fazendo com que seu valor represente uma quantia 
impensável a se pagar por uma publicação. No entanto, Scott (1991, p.28) lembra que isso não ocorre com todos os arcos e completar alguns mais populares não seria tão difícil.

\subsection{Os frequentadores da gibiteca de Santos - depoimentos e entrevistas}

Ao longo dos seus 25 anos de existência, artistas, leitores de quadrinhos, pessoas de todas as idades e de diversas partes do país estiveram na Gibiteca. Por isso, considerar o que alguns de seus frequentadores afirmam sobre o espaço, pode ilustrar o que os teóricos elencados para a confecção desta pesquisa atestam sobre a importância dos eventos e dos locais como as gibitecas para a população dos locais onde estão inseridas.

Na perspectiva da Geografia Cultural (CORRÊA; ROSENDAHL, 2007, p. 171), a cultura é elaborada a partir de significados comuns em um dado grupo social. Estes significados, assim como as técnicas e crenças compartilhadas e que são traduzidos em representações e práticas, dão sentido ao grupo. Nesse sentido, a cultura

resulta da capacidade dos seres humanos se comunicarem entre si por meio de símbolos. Quando as pessoas parecem pensar e agir similarmente, elas o fazem porque vivem, trabalham e conversam juntas, aprendem com os mesmos companheiros e mestres, tagarelam sobre os mesmos acontecimentos, questões e personalidades, observam ao seu redor, atribuem o mesmo significado aos objetos feitos pelo homem, participam dos mesmos rituais e recordam o mesmo passado. Inversamente, grandes diferenças de pontos de vista e atividades geralmente refletem a ausência de símbolos e língua comum. Assim, a cultura também está assentada em uma base geográfica, pois é provável que só ocorra comunicação regular e compartilhada entre pessoas que ocupam uma área comum. (WAGNER; MIKESELL, apud CORTEZ, 2013, p. 199)

Sobre as impressões de suas incursões à Gibiteca de Santos, Osvaldo da Costa Apêndice B), cartunista, professor de Artes Visuais e pesquisador de quadrinhos, afirma que ao se aproximar da população por meio dos cursos de desenho que já ministrou na Gibiteca, acredita que pode conhecer outro perfil de sua própria cidade, pois artistas que encontrou no local, trouxeram experiências e conhecimentos de suas áreas de atuação que 
contribuem para o desenvolvimento do trabalho de outros artistas em geral. Em seu depoimento, lembra da primeira oficina que participou:

\begin{abstract}
Uma das primeiras visitas que fiz a Gibiteca foi numa palestra da prof. Sonia Luyten, sobre a arte sequencial, com muito entusiasmo, ela nos falava sobre a produção de Hqs no Japão e o interesse dos japoneses por Hqs brasileiras. O que é Mangá era a pergunta que se fazia no encontro. Era final de tarde, foi dada a palavra, como estava e andava a produção de quadrinhos no Brasil. Participei de alguns encontros sobre desenho, humor gráfico, exposições de cartuns e charges. A arte e a filosofia da contra-cultura na obra do cartunista Glauco, foi um preâmbulo de um texto abandonado na gaveta. Apresentei nesse encontro, o um resumo da origem do humor, comportamento e contestação num período pós-ditadura na obra do cartunista. (Apêndice B)
\end{abstract}

Alexandre Alves Barbosa, também cartunista, professor de Artes Visuais e pesquisador de quadrinhos, trabalhou pessoalmente com Marcel Rodrigues Paes no jornal A Tribuna de Santos. Sua história pessoal se confunde com a da própria Gibiteca, uma vez que acompanhou não só projeto de sua criação, como ao longo de seus 25 anos de existência ministrou cursos, participou de exposições e bate-papos ativamente (Apêndice B). Para ele, a importância do local reside na sua capacidade de formar leitores e produtores de histórias em quadrinhos.

Para um dos respondentes do questionário (Apêndice A), foi por meio da Gibiteca que seus filhos se aproximaram da literatura devido à sua frequência ao equipamento. Os respondentes também afirmaram que, entre os motivos de frequentarem o local, estão: "Encontrar pessoas que curtem o mesmo hobby, ler algo antes de comprar, devido ao ambiente ser descontraído e confortável, a possibilidade de ler raridades que não teria acesso, conhecer novos autores, a variedade de títulos, conhecer as publicações independentes..."

Já em relação aos eventos, os respondentes afirmam que as vantagens da realização das atividades na Gibiteca estão: "Promover conteúdo que não é conhecido pela população em geral, difundir a leitura entre as crianças, atrair público, divulgação dos quadrinhos nacionais, fazer amigos, reencontrar velhos amigos, socialização de pessoas de várias idades, integra autores e fãs, fomenta a cultura, agrega conhecimento”. 
As respostas e depoimentos ilustram o que Pustz (2000) atesta ao longo de seu livro sobre o perfil dos fãs e leitores de histórias em quadrinhos, principalmente quando ele se refere à necessidade destas pessoas de se sentirem parte de um grupo que compartilha os mesmos gostos e opiniões acerca de algo.

Nesse sentido, não é possível dissociar os leitores de quadrinhos e suas práticas do que Pustz (2000) define como a cultura das histórias em quadrinhos, da mesma forma que não é possível dissociar a Gibiteca de seus frequentadores. Essa relação, entre os seres humanos e seus locais de encontro para realização dos mais diversos eventos é interpretado pelos estudiosos da Geografia Cultural como uma relação específica que pode ser observada a partir do papel que estes espaços significam para seus usuários. A influência que os atores envolvidos nessas interações exercem no meio onde estão inseridos ou a forma como os conteúdos são repassados adiante, depende da circulação desses conteúdos para além dos limites geográficos dos espaços onde ocorrem. Assim,

uma comunidade de pessoas que compartilha uma cultura comum pode existir encravada em uma única aldeia isolada, na qual todos os habitantes estão em contato direto diário, ou pode se estender sobre um vasto território dentro do qual pessoas, objetos e ideias circulam mais ou menos livre e continuamente. Uma cultura passa a se difundir quando os que a compartilham se deslocam, ou quando sua correspondente esfera de comunicação, e os símbolos aí incluídos, prevalecem sobre os de outras culturas em novos territórios. (CORTEZ, 2013, p.200)

Tendo em mente a perspectiva trazida por Cortez (2013) sobre a forma que os significados são compartilhados a partir de uma determinada cultura, quando os artistas que frequentaram os cursos oferecidos na Gibiteca de Santos passam a ministrar seus próprios cursos e publicam suas próprias histórias em quadrinhos, estão compartilhando o conhecimento adquirido em um espaço específico por meio da circulação de suas ideias em outras esferas que ultrapassam não só os limites geográficos físicos, como simbólicos também, difundindo a cultura das histórias em quadrinhos entre outros grupos, em outros meios que não necessariamente compartilhavam dos mesmos elementos constitutivos dessa cultura, como é o caso das livrarias onde podem ser encontrados os mais variados gêneros de quadrinhos no formato de graphic novels. 
Em relação à Gibiteca de Santos, os apontamentos feitos por seus frequentadores mais assíduos demonstram que, ainda que haja problemas referentes à acomodação dos quadrinhos, o cuidado que os visitantes têm ao manuseá-los permite que os exemplares estejam sempre em boas condições de uso, como foi observado por Jonas dos Santos, de 63 anos e que há pelos menos 10 anos frequenta a Gibiteca diariamente para ler as revistas do seu personagem favorito, o Tex.

Tanto para Jonas, como para Reinaldo Garcia, de 53 anos e que frequenta assiduamente a Gibiteca há 3 anos para ler quadrinhos do Batman, o interesse nas revistas antigas está no fato de que elas não são facilmente encontradas em sebos ou lojas especializadas e o acervo disponível na Gibiteca possibilita não só que eles relembrem as aventuras dos personagens com os quais se identificam, como tenham acesso às histórias que não conheciam ${ }^{64}$.

Quanto às crianças que visitam o local nos dias de semana, geralmente trazidas pelas escolas onde estudam, Danielle Salomão, que esteve presente na Gibiteca no dia 26 de abril de 2018, com a escola de educação infantil Tatibitati (Figura 34), afirma que é importante que as crianças tenham contato com as histórias em quadrinhos mesmo antes de saberem ler. O grupo levado pela pedagoga era composto por crianças de 4 e 5 anos, em fase de pré-alfabetização, por isso, as monitoras que acompanhavam o grupo, sentavam em círculo, liam as histórias, sempre mostrando as imagens e fazendo perguntas sobre o que haviam contado, a fim de checar a compreensão das crianças sobre o que foi passado. Dessa forma, o vínculo com personagens e com a narrativa é desenvolvido e facilmente observável, pois quando perguntadas sobre os nomes de seus personagens favoritos, grande parte das crianças demonstrou conhecer os nomes presentes nas revistas.

\footnotetext{
${ }^{64}$ Entrevistas realizadas presencialmente na Gibiteca de Santos no dia 26/04/2018.
} 
Figura 34 - Visita da escola Tatibitati - 26/04/2018

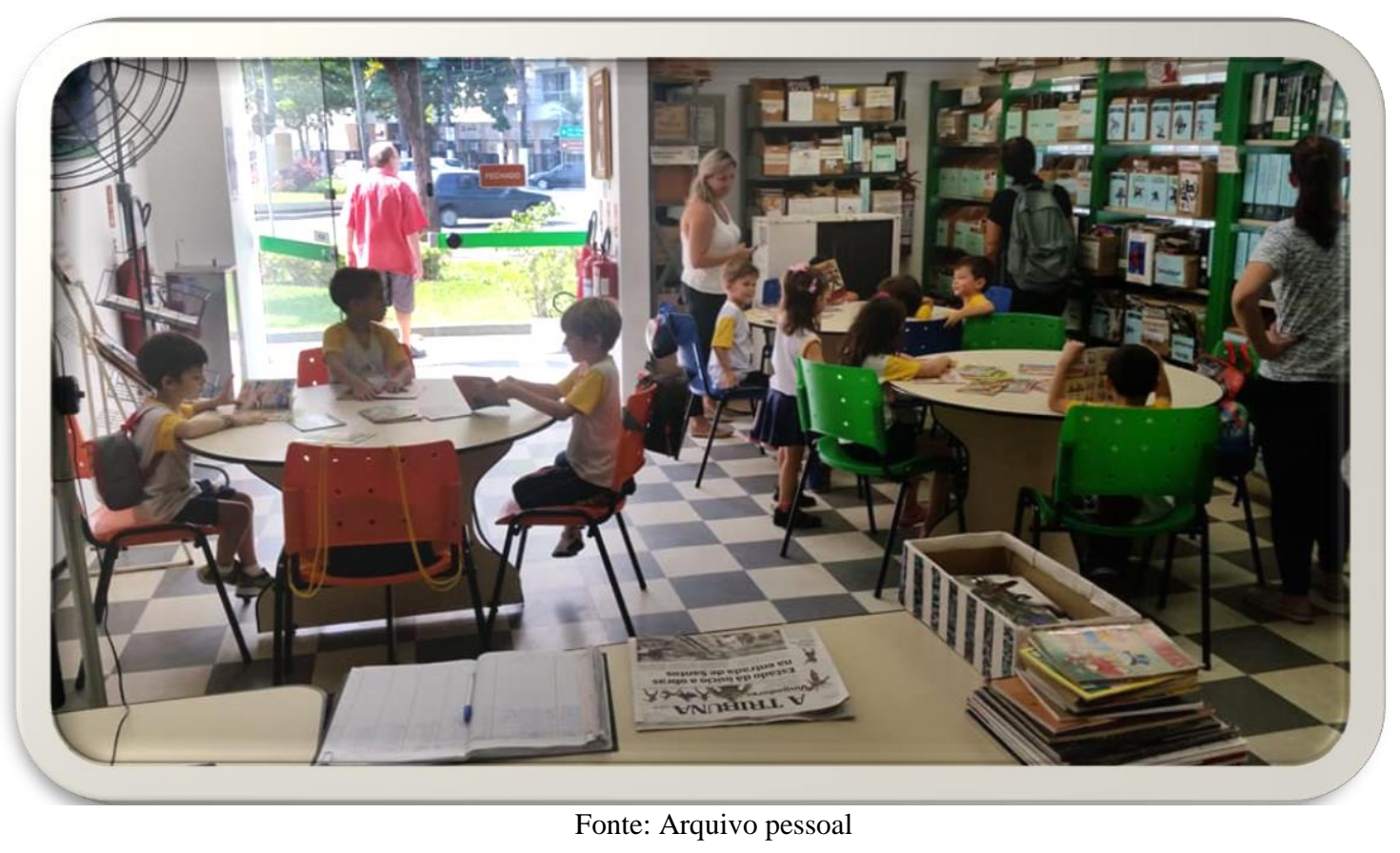

Embora as crianças que frequentam a Gibiteca durante a semana nem sempre sejam alfabetizadas, o contato precoce com os quadrinhos pode determinar a forma que elas irão lidar com eles quando estiverem maiores. Scott (1991, p.13) acredita que muito da resistência em relação aos quadrinhos possa ter a ver com as práticas de leitura e alfabetização das pessoas: Para aqueles que aprenderam a ler antes de consumir quadrinhos, as histórias podem não fazer muito sentido porque é exigido do leitor um esforço extra para aprender as "regras" de leitura desse tipo de publicação.

Ou seja, ainda que haja certo preconceito em relação às histórias em quadrinhos, seja por parte da sociedade, dos bibliotecários, do poder público ou da Academia, os professores da educação infantil parecem entender que é na gibiteca que leitores podem ter acesso a uma diversidade ilimitada de material que pode oferecer uma experiência que vai muito além do entretenimento; por isso, promover o contato das crianças com os quadrinhos mesmo antes da alfabetização, seja por meio da contação das histórias ou meramente por seu manuseio, pode representar um fator significativo para a forma que a sociedade irá lidar com os quadrinhos no futuro. 


\section{CONSIDERAÇÕES FINAIS}

A partir das considerações dos teóricos elencados na pesquisa, é possível observar que ainda que a cultura tenha se caracterizado, por muito tempo, como um fato aristocrático o processo de democratização do acesso aos produtos culturais resultou em mudanças significativas na maneira como as pessoas passaram a consumir e apreciar a cultura em suas mais diversas manifestações.

Assim, ao longo das últimas décadas, mais espaços dedicados a exposições, shows, produções culturais diversas têm surgido no Brasil, seja por meio de iniciativas privadas ou públicas e entre esses espaços, estão as gibitecas.

Para concluir se as gibitecas podem ser consideradas polos de fomento à cultura e de exercício da cidadania por meio dos eventos que realiza, foi necessário contextualizar o papel das histórias em quadrinhos como produtos culturais de mesmo valor que outras manifestações artísticas, indicando que o seu consumo pode nos beneficiar em diversos âmbitos da vida que vão desde o entretenimento e lazer à aquisição de conhecimento e formação se senso crítico por meio do seu conteúdo.

Nesse sentido, a pesquisa sobre gibitecas para fins de contextualização do surgimento da Gibiteca de Santos, indicou que, ainda que outros espaços destinados à difusão cultural possam representar meios de transmissão cultural, as gibitecas, por conterem em seu acervo produtos que até há pouco tempo não eram compreendidos como bens culturais legítimos, nem sempre são consideradas por gestores públicos como espaços que merecem a mesma atenção que os demais equipamentos destinados às exposições e eventos culturais. Por isso, a demonstração de dados que justifiquem sua necessidade pode fornecer subsídios necessários para que elas sejam mantidas.

A partir da observação dos eventos sociais, expressões que eram tidas como elementos de uma subcultura, com valor social e cultural considerados menores por integrarem um conjunto de práticas que se entendia como cultura de massa, passaram a ser compreendidas por teóricos das Ciências Sociais e Humanas como expressões legítimas e de valor equivalente às demais manifestações artísticas já legitimadas. Entre essas manifestações, encontram-se as histórias em quadrinhos.

A existência de uma cultura dos quadrinhos, que contempla uma série de elementos e práticas que são peculiares ao universo dos quadrinhos, e que envolvem desde o 
desenvolvimento de literacia e gramáticas próprias, além uma série de outros conhecimentos que são compartilhados pelos fãs e leitores de suas histórias, indica que sua decodificação requer recursos e ferramentas específicas que são adquiridas na medida em que seus consumidores se familiarizam com as narrativas, atividade que pode ser realizada em espaços culturais classificados de acordo com suas relações externas, nos possibilitando entender que as gibitecas poderiam facilmente estar inseridas nas categorias mencionadas no segundo capítulo da dissertação

Portanto, seria apenas natural que os quadrinhos dispusessem dos mesmos investimentos e espaços para que fossem apreciados, tal qual ocorre com as demais manifestações artísticas. Uma das formas de se justificar a existência desses espaços, é por meio da demonstração de que eles estão sendo utilizados e, uma forma de levar a população a esses espaços, é via realização frequente de eventos que propiciem a aproximação da comunidade com os quadrinhos.

Quanto aos eventos, é possível afirmar que sua realização desempenha um papel fundamental para a compreensão dos fenômenos de comunicação, entre eles, os que envolvem os produtos de cultura de massa. A importância desses espaços de difusão cultural como espaços de aquisição de significados reside em sua possibilidade de gerar bem-estar à comunidade onde estão inseridos.

No que tange aos eventos realizados na Gibiteca de Santos, algumas observações podem ser feitas em relação aos seus efeitos práticos. Entre esses efeitos, é possível citar, por exemplo, o surgimento de um grupo de frequentadores assíduos da Gibiteca de Santos, que, ao trocarem experiências sobre o uso de quadrinhos em suas aulas, adquiriram novas formas e perspectivas de utilizar materiais diferentes em suas práticas pedagógicas, promovendo mudanças sensíveis no meio em que atuam, de acordo com depoimentos feitos por eles quando participaram de atividades no local. Os visitantes também conhecem novas obras e adquirem quadrinhos nos eventos realizados, ajudando a fomentar a produção nacional, se aperfeiçoam tecnicamente e divulgam seus trabalhos em exposições que são levadas a outros espaços culturais da cidade.

Assim, há um processo que possibilita justificar a existência e a manutenção das gibitecas públicas como espaços necessários para o fomento à cultura e para o exercício da cidadania. Esse processo parte da premissa que, ao serem legitimados como elementos de um campo cultural, além de serem, no caso do Brasil, protagonistas na alfabetização 
infantil, os quadrinhos precisariam inevitavelmente de locais para que possam ser apreciados e consumidos.

No entanto, o simples fato de os acervos existirem nas gibitecas nem sempre garante que os leitores as frequentem de forma assídua e isso se deve a diversos fatores, entre eles, podemos citar o alto índice de analfabetismo funcional e a falta de hábitos de leitura e de frequência às bibliotecas públicas em geral, além da forte associação dos quadrinhos ao entretenimento infantil e o acesso às versões digitalizadas dos quadrinhos, os scans.

Com a popularização dos filmes baseados em histórias em quadrinhos e o aquecimento do mercado nacional indicado pelos números divulgados pelas organizações dos eventos de quadrinhos, o interesse do público por atividades relacionadas à Nona Arte também tem aumentado. Esse interesse pode ser medido em índices como os do site da Amazon, que aponta para o aumento de vendas de itens de cultura pop como quadrinhos, camisetas, colecionáveis...Entre as cidades com maior número de consumidores de itens considerados "geek", está a cidade de Santos.

Os números da Amazon também indicam que existe um público consumidor que pode pagar pelos produtos "geek", no entanto, o acesso à cultura constitui um direito básico de todos os cidadãos previsto nos parâmetros de cultura e desenvolvimento da UNESCO e deve ser gratuito. De acordo com os relatórios do órgão no Brasil, a relação entre acesso à cultura e direitos humanos, bem como seu papel na luta contra discriminação, é uma das questões enfrentadas no país, onde quase todos os brasileiros nunca frequentaram uma exposição de arte ou bibliotecas: “A focalização das políticas culturais nos níveis estaduais e municipais pode favorecer a superação desse quadro e reforçar a diversidade cultural como fator da sustentabilidade do desenvolvimento" ${ }^{65}$

A partir da ideia de que por meio do acesso à cultura nós exercemos nossa cidadania e por meio dos eventos e exposições nós podemos conhecer diversas formas de expressões artísticas, as gibitecas, por representarem espaços onde os quadrinhos podem ser apreciados e por promover atividades que visam aprofundar o conhecimento de seus visitantes acerca de um mercado do qual eles podem fazer parte, seja como consumidores ou futuros artistas, cumprem então seu papel social como qualquer outro local destinado ao fomento das artes.

O principal objetivo da pesquisa foi demonstrar que as gibitecas podem representar polos de fomento à cultura e de exercício da cidadania, por meio da realização de eventos

\footnotetext{
${ }^{65} \mathrm{http}: / / \mathrm{www} . u n e s c o . o r g /$ new/pt/brasilia/culture/culture-and-development/access-to-culture/
} 
que aproximem a população das histórias em quadrinhos e com o desenvolvimento dos estudos que envolveram principalmente a participação ativa nesses eventos. Dessa forma, foi possível constatar que, embora os quadrinhos ainda possam sofrer alguma rejeição por parte pais, professores ou bibliotecários, os dados sobre os frequentadores da Gibiteca indicam que os eventos têm sido responsáveis pelo aumento no número de visitantes nos dias em que são realizados e isso se deve a motivos específicos listados nas respostas ao questionário online (Apêndice $\mathrm{A}$ ).

Então, é possível considerar, que não só as gibitecas constituem polos de fomento à cultura e de exercício da cidadania, como sua manutenção deveria estar atrelada ao fato de que os quadrinhos são produtos culturais cujo valor não pode mais ser questionado, uma vez que seu processo de legitimação cultural vem sendo consolidado há algumas décadas e que a existência de uma cultura própria, formada por elementos típicos, vem sendo atestada por diversos teóricos do meio acadêmico de pesquisas sobre histórias em quadrinhos.

Por fim, a trajetória percorrida ao longo da confecção da dissertação demonstra que os aspectos quantitativos da pesquisa, mesmo que constituíssem um corpus mais extenso, seriam insuficientes para ilustrar os argumentos dos autores citados, pois, dentro da perspectiva de que a cultura é constituída de elementos subjetivos que são inerentes às manifestações humanas, os números seriam incapazes, por si só, de conferir a dimensão dos aspectos emocionais que são atrelados à aquisição de conteúdo e atribuição de significados, pois estas são tarefas pertencentes ao âmbito qualitativo da pesquisa.

São esses aspectos que certamente se conectam ao fato de o número de frequentadores da Gibiteca estar aumentando nos dias em que os eventos são realizados, pois, apenas a partir da participação das atividades, é possível compreender o que significa para um adolescente ter contato com um artista de sua cidade que desenha seu super-herói favorito em uma grande editora ou o que significa para um frequentador que deseja se tornar desenhista, saber que seu colega de gibiteca foi escolhido para contar a história de um dos personagens mais icônicos das histórias em quadrinhos brasileiras.

Acredito que o pensamento de Mário Quintana que diz "livros não mudam o mundo, livros mudam as pessoas e pessoas mudam o mundo", possa ser atribuído aos quadrinhos, principalmente se considerarmos o potencial de identificação que super-heróis são capazes de gerar. E que lugar melhor para conhecer seus heróis favoritos se não em uma gibiteca, onde além de ter acesso gratuito às histórias, o visitante ainda pode aprender 
a desenhar e socializar com pessoas que compartilham sentimentos capazes de fornecer novos significados às suas experiências?

Histórias em quadrinhos não mudam o mundo. As pessoas mudam o mundo e as histórias em quadrinhos mudam as pessoas. 


\section{Referências}

ABUD, Hugo Leonardo; PINHO, Maria Helena S. Corrêa. Gibiteca Henfil: 20 anos de jornada na $1^{\text {a }}$ jornadas internacionais de história em quadrinhos. $1^{\text {as }}$ Jornadas Internacionais de Histórias em Quadrinhos, Universidade de São Paulo. São Paulo, 2011

ALBUQUERQUE, Soraya Sousa. Turismo de Eventos: A importância dos eventos para o desenvolvimento do turismo. Trabalho de Conclusão de Curso - Universidade de Brasília. Brasília, 2004. Disponível em:

http://bdm.unb.br/bitstream/10483/438/1/2004_SorayaSousaAlbuquerque.pdf $>$. Acesso em: 12 Mai. 2018.

BARBIERI, Daniele. A Linguagem dos Quadrinhos. Peirópolis, São Paulo, 2017.

BARI, Valéria Aparecida. O Potencial das Histórias em Quadrinhos na Formação de Leitores: busca de um contraponto entre os panoramas culturais brasileiro e europeu. São Paulo: 2008. Tese (Doutorado em Cultura e Informação) - Escola de Comunicações e Artes da Universidade de São Paulo. Disponível em: <http://www.teses.usp.br/teses/disponiveis/27/27151/tde-27042009121512/pt-br.php>. Acesso em: 02 abr. 2016.

BAUMAN, Zygmunt. A cultura no mundo líquido. Rio de Janeiro: Zahar, 2013.

BORGES, Renata Farhat de Azevedo. Clássicos e Seus Editores no Brasil: o ímpeto na produção de adaptações literárias no século XXI. Tese de Doutorado - Escola de Comunicações e Artes/ Universidade de São Paulo, São Paulo, 2016. Disponível em: http://www.teses.usp.br/teses/disponiveis/27/27154/tde-17032017-160918/en.php. Acesso em 27 mar. 2017.

CALLARI, Victor; GENTIL, Karoline Kunieda. As pesquisas sobre quadrinhos nas universidades brasileiras: Uma análise estatística do panorama geral e entre os histpriadores. Revista do programa de pós-graduação em História., v. 4, n.7. Universidade de Brasília. Brasília, 2016. Disponível em: < http://periodicos.unb.br/index.php/hh/article/view/16292>. Acesso em 13 Mai. 2018.

CAMPOS, Rogério de. Imageria: o nascimento das histórias em quadrinhos São Paulo: Veneta, 2015.

CANCLINI, Néstor Garcia. Culturas Híbridas: estratégias para entrar e sair da modernidade.3. ed. São Paulo: Edusp, 2000.

Consumidores e cidadãos: Conflitos Multiculturais da Globalização. Rio de Janeiro, UFRJ, 1999.

CARVALHO, Beatriz Sequeira de. O processo de legitimação cultural das histórias em quadrinhos. Dissertação de Mestrado. ECA/USP, São Paulo, 2017. Disponível em:

http://www.teses.usp.br/teses/disponiveis/27/27154/tde-31102017-123128/pt-br.php > Acesso em 15 Mai 2018.

CONSONI, Karize Pereira. Artista, obra e público: reflexões sobre as possibilidades de interação com a arte contemporânea. Trabalho de Conclusão de Curso - Universidade do Extremo Sul Catarinense - UNESC. Criciúma, 2013. Disponível em: < http://repositorio.unesc.net/bitstream/1/1860/1/Karize\%20Pereira\%20Consoni.pdf $>$ Acesso em 12 Mai. 2018. 
CORRÊA, Roberto Lobato; ROSENDAHL, Zeny (org.). Introdução à geografia cultural. Rio de Janeiro: Bertand Brasil, 2007

CORTEZ, Glauco Rodrigues. Espaços de Comunicação, Cultura e Dessignificação. In Matrizes: Revista do Programa de Pós-Graduação em Ciências da Comunicação da Universidade de São Paulo, São Paulo, Ano 7, V. 7 - n. 1, jan.-jun., 2013. P. 197-206. Disponível em: http://www.revistas.usp.br/matrizes/article/view/56653/59677 >. Acesso em 24 mar. 2017.

COSGROVE, Denis E. Em Direção a uma Geografia Cultural Radical: Problemas da Teoria. In: CORRÊA, R. L.; ROSENDHAL, Zeny (Org.) Geografia Cultural: Um Século (2). Rio de Janeiro, Bertrand Brasil, 2007.

CUCHE, Denys. A noção de cultura nas ciências sociais. $2^{\mathrm{a}}$ edição, Bauru, EDUSC, 2002.

CURTIN, Michael. Política de Comunicação no século XXI: do interesse nacional à gestão cultural. In: Dossiê: Novas Perspectivas em Teorias da Comunicação - Matrizes: Revista do Programa de Pós-Graduação em Ciências da Comunicação da Universidade de São Paulo, São Paulo, Ano 9, n. 1, jan.-jun. 2015. Disponível em: http://www.revistas.usp.br/matrizes/article/view/100671/99398>. Acesso em 24 mar. 2017.

DANNER, Alexander; MAZUR, Dan. Quadrinhos: História Moderna de Uma Arte Global. Martins Fontes, São Paulo, 2014.

DIÁRIO OFICIAL. Santos, 2014.2 Disponível em: https://diariooficial.santos.sp.gov.br/edicoes/leitura/mobile/2014-12-08/1. Acesso em 08 mai. 2018.

ECO, Umberto. Apocalípticos e Integrados - 2a edição. Perspectiva, São Paulo,1974.

FRANÇA, Vera Veiga. Crítica e Metacrítica: Contribuição e Responsabilidade das teorias da Comunicação. In: Dossiê: Novas Perspectivas em Teorias da Comunicação - Matrizes: Revista do Programa de Pós-Graduação em Ciências da Comunicação da Universidade de São Paulo, São Paulo, Ano 8, n. 2, jul.-dez. 2014. Disponível em: http://www.revistas.usp.br/matrizes/article/view/90449/93223>. Acesso em 24 mar. 2017.

GEERTZ, Clifford. A Interpretação das Culturas. Rio de Janeiro: LTC, 1989.

GOIDANICH, Hiron Cardoso. Enciclopédia dos quadrinhos. Porto Alegre: L\&PM, 1990.

GROESTEEN, Thierry. O Sistema dos Quadrinhos. Marsupial, Rio de Janeiro, 2015.

HALL, Stuart. A identidade cultural na pós-modernidade. 9. ed. Rio de Janeiro: DP\&A, 2004.

Da Diáspora: identidades e mediações culturais. Belo Horizonte, Editora UFMG, 2003.

LIPOVETSKY, Gilles e SERROY, Jean. A estetização do mundo: viver na era do capitalismo artista. Companhia das Letras, São Paulo, 2015.

LOCCO, Clayton In. Receptação é Crime. Projeto Luan Vive. Prefeitura Municipal de Santos, 2016.

LUYTEN, Sonia Bibe. Mangá Produzido no Brazil: Pioneirismo, Experimentação e Produção. In Congresso Internacional de Comunicação - INTERCOM. Belo Horizonte, 2003. Disponível em: http://www.intercom.org.br/papers/nacionais/2003/www/pdf/2003_NP16_luyten.pdf. Acesso em 27 mar. 2017. 
MAIA, Rouseley. Emoção, retórica e histórias pessoais na esfera pública. In: SOARES, M.C., et al. Mídia e Cidadania. São Paulo: Cultura Acadêmica, 2012.

MARINO, Daniela; NOGUEIRA; Natania. Gibitecas como espaços de formação de leitor e exercício da cidadania. In BRAGA, Amaro; MODENESI, Thiago (org) Quadrinhos e Educação: Fanzines, espaços e usos pedagógicos. Vol. 3. Faculdade dos Guararapes, Recife, 2016.

MARSHALL, T. H. Cidadania, classe social e status. Rio de Janeiro: Zahar, 1967.

MARTÍN-BARBERO, Jesús. Dos Meios às Mediações: Comunicação, cultura e hegemonia. Rio de Janeiro: Editora UFRJ, 1997.

; BARCELLOS, Claudia. Comunicação e mediações culturais Diálogos Midiológicos - 6. Entrevista de Martín-Barbero. Revista Brasileira de Comunicação. Vol. XXIII, $\mathrm{n}^{\circ} 1$, janeiro/junho de 2000, p. 151-163. Disponível em: 〈http://www.portcom.intercom.org.br〉. Acesso em: 04 abr. 2016.

MATO, Daniel. Stuart Hall a partir da América Latina. Matrizes. P. 47-65- V.9 - No 2 jul./dez. São Paulo, 2015.

MATTELART, A. e NEVEU, E. Los cultural studies: hacia una domesticación del pensamiento salvaje. La Plata. Editora Universidad Nacional de La Plata, 2002.

MCCLOUD, Scott. Understanding Comics: The Invisible Art. Northampton, Mass. : Kitchen Sink Press, 1993.

MORESI, Eduardo (org). Metodologia da Pesquisa. Programa de pós-graduação da Universidade

Católica de Brasília. 2003. Disponível em: xx<http://www.inf.ufes.br/ falbo/files/MetodologiaPesquisa-Moresi2003.pdf >. Acesso em 09 abr. 2016.

NICOLAU, Vitor. Tirinhas e Mídias Digitais. João Pessoa, Marca de Fantasia, 2013. Disponível em: http://www.insite.pro.br/elivre/vitor_nicolau_pc.pdf Acesso em 13 abr. 2017.

NOGUEIRA, Natania A. S. Gibiteca: Ensino, Criatividade e Integração Escolar. Anais eletrônicos, vl 7. Curitiba: EDUCERE, 2007. Disponível em: <http://www.pucpr.br/eventos/educere/educere2007/anaisEvento/arquivos/CI-020-05.pdf >. Acesso em: 08 abr. 2016.

, Natania A. S. As Histórias em quadrinhos e a escola. Leopoldina, Ed. Aspas, 2017.

OLIVEIRA, Rebeca Socorro Fontes. A mediação de leitura para surdos utilizando o recurso da quadrinhização. Trabalho de Conclusão de Curso - Universidade Federal de Sergipe. Sâo Cristovão, 2017. Disponível em: https://ri.ufs.br/bitstream/riufs/6714/2/Rebeca\%20Socorro\%20Fontes\%20de\%20Oliveira.pdf >. Acesso em 12 Mai. 2018.

ORLIKOWSKI, W.; BAROUDI J. J. Studying Information Technology In Organizations: Research Approaches and Assumptions. Information Systems Research, v. 2, n. 1, pp 1-28, 1991. Disponível em: <http://dx.doi.org/10.1287/isre.2.1.1>. Acesso em: 08 abr. 2016.

PEGORARO, Celbi Vagner Melo. Animação e quadrinhos Disney: produção cultural no início do século XXI. Tese de doutorado - Universidade de São Paulo. São Paulo, 2015. Disponível em: < http://www.teses.usp.br/teses/disponiveis/27/27154/tde-01022017-103935/pt-br.php>. Acesso em 12 Mai. 2018.

PERUZZO, Cicilia M. Krohling. Comunicação Comunitária e educação para a cidadania. Comunicação e Sociedade 2. Cadernos do Noroeste: série Comunicação Vol. 14, Braga, Portugal, 
2000. Disponível em: http://revistacomsoc.pt/index.php/comsoc/article/viewFile/1427/1358. Acesso em: 12 de setembro 2016.

PUSTZ, Matthew. Comic Book Culture: Fanboys and True Believers. Mississipi University, 2000.

RAMOS, Paulo. Pontos de Fuga: Registros do Processo de Alargamento do Formato das Tiras. São Paulo: Revista 9a Arte, v. 3, $\mathrm{n}^{\mathrm{o}}$ 1, 2014. Disponível em: http://www2.eca.usp.br/nonaarte/ojs/index.php/nonaarte/article/view/96/117 Acesso em 13 abr. 2017.

SCHWANDT, Thomas A. Constructivist, Interpretivist Approaches to Human Inquiry. In: Denzin, Norman K. Handbook of qualitative research. Thousand Oaks: Sage, 1994. Disponível em: <https://www.researchgate.net/publication/232477264_Constructivist_Interpretivist_Approaches _to_Human_Inquiry>. Acesso em: 08 abr. 2016.

SCOTT, Randall W. Comics Librarianship: A Handbook. Mc Farland. Londres, 1991.

SEVERO, Luana Diehl. Elementos para uma política de indexação de histórias em quadrinhos. Trabalho de Conclusão de Curso - Universidade Federal do Rio Grande do Sul. Porto Alegre, 2012. Disponível em: < http://www.lume.ufrgs.br/handle/10183/54263> . Acesso em 12 Mai. 2018.

SIGNATES, Luiz. Estudo sobre o conceito de mediação. Grupo de Estudos sobre Práticas de Recepção a produtos mediáticos - ECA/USP. Novos Olhares. Ano $6 \mathrm{n}^{\circ}$ 12. São Paulo. 2012. Disponível em: www.revistas.usp.br/novosolhares/article/download/51315/55382 Acesso em: 12 Mai. 2018.

SILVA, Alexandre Honorio da. Os scans e seu entorno subcultural-colaborativo. Revista Famecos, v. 24, n.2. Porto Alegre, 2017. Disponível em: < http://revistaseletronicas.pucrs.br/ojs/index.php/revistafamecos/article/view/24841/0>. Acesso em 15 Mai. 2018.

TAKAHASHI, Thiago Seiji. A potencialidade dos quadrinhos na educação corporativa: gibis impressos, digitais e Graphic Novels. 2015. Dissertação (Mestrado em Estudo dos Meios e da Produção Mediática) - Escola de Comunicações e Artes, Universidade de São Paulo, São Paulo, 2015. Disponível em:

http://www.teses.usp.br/teses/disponiveis/27/27153/tde-14012016-100117/pt-br.php. Acesso em 12 abr. 2017.

VERGUEIRO, Waldomiro. A odisséia dos quadrinhos infantis brasileiros: Parte 1: De O Tico-Tico aos quadrinhos Disney, a predominância dos personagens importados. Hagaque, vol 1, ano 2, julho $1999 . \quad$ Disponível em http://www.eca.usp.br/nucleos/nphqeca/agaque/ano2/numero1/indexn1v2.htm. Acesso em 12 abr. 2017.

As gibitecas: um espaço privilegiado para a difusão de histórias em quadrinhos. 2003a. In: INFOHOME. Disponível em: <www.ofaj.com.br/colunas_conteudo.php?cod=140> acesso em: 12 Mai. 2018.

Comic Books Collections in Brazilian Public Libraries: The Gibitecas. In New Library Word. P. 14-18, v. 95, n. 1117, MCB University Press Limited:Inglaterra, 1994.

Histórias em quadrinhos, bibliotecas e bibliotecários: uma relação de amor e ódio. 2003b. In: INFOHOME. Disponível em: < http://www.ofaj.com.br/colunas_conteudo.php?cod=137> acesso em: 12 Mai. 2018

Histórias em quadrinhos e serviços de informação: um relacionamento em fase de definição. DataGramaZero, $\quad$ v. $\quad 6, \quad$ n. $\quad 2, \quad$ p. $00-00, \quad 2005$. Disponível em: < 
http://www.brapci.inf.br/index.php/article/view/0000001585/f27caf52f00b14b55cc64d950f2a6a79/ >. Acesso em: 13 Mai. 2017.

Panorama das Histórias em Quadrinhos no Brasil. Peirópolis, São Paulo, 2017a.

Pesquisa Acadêmica em Histórias em Quadrinhos. Criativo, São Paulo, 2017b.

VERGUEIRO, Waldomiro. SANTOS, Roberto Elísio dos. A pesquisa sobre histórias em quadrinhos na Universidade de São Paulo : análise da produção de 1972 a 2005. São Paulo. Unirevista, vol. 1, nº 3, 2006.

VERGUEIRO, Waldomiro; RAMOS, Paulo (orgs). Quadrinhos na Educação: da rejeição à prática. Contexto. São Paulo. 2009.

VERGUEIRO, Waldomiro; RAMOS, Paulo; CHINEN, Nobuyoshi (orgs). Os Pioneiros no Estudo de Quadrinhos no Brasil. Criativo, São Paulo, 2013.

WILLIAMS, Raymond. Cultura. Paz e Terra, São Paulo, 2008.

The Long Revolution. Pelican Edition, Austrália, 1961.

WRIGHT, Frederick. How Can 575 Comic Books Weigh Under an Ounce?: Comic Book Collecting in the Digital Age. V. 11, Issue 3, Fall 2008. Disponível em: <https://quod.lib.umich.edu/j/jep/3336451.0011.304/--how-can-575-comic-books-weigh-underan-ounce-comic-

book?rgn=main;view=fulltext;q1=How + Can $+575+$ Comic + Books + Weigh + Under + an + Ounce.$>A$ cesso em 15 ago. 2017.

TILLEY, Carol. Seducing the innocent: Fredric Wertham and the falsifications that helped condemn comics. Information \& Culture, v. 47, n. 4, p. 383-413, 2012. 


\section{ANEXOS}

ANEXO 1 - Relatório de atividades da Gibiteca de Santos

ANEXO 2 - Tabelas dos eventos realizados por data 


\section{ANEXO 1 - RELATÓRIOS DE ATIVIDADES DA GIBITECA DE SANTOS}

\section{Registros de atividades e do número de participantes}

\section{Apresentação}

Os relatórios de atividades da Gibiteca Municipal de Santos se baseiam no número de pessoas que assinam a lista de presença do dia que visitaram a gibiteca e, no caso de cursos e oficinas, no número de pessoas inscritas e presentes em cada aula.

Apenas a partir de 2015 que a Gibiteca passou a disponibilizar um caderno de visitas exclusivo para registrar a presença dos visitantes nos dias de evento. Até então, havia um único caderno sem divisão de dias ou eventos.

Nos dias úteis, o caderno de visitas fica disponível na mesa onde os visitantes devolvem as revistas que leram para que sejam guardadas pelos funcionários presentes. No entanto, nem todos os visitantes assinam o caderno.

Nos dias de curso e aulas, os funcionários conferem a lista de inscritos e verificam se todos os inscritos estão presentes, registrando os dados em um caderno exclusivo para esse fim.

Os relatórios referentes aos anos de 2013, 2014, 2015 e 2016 foram apresentados publicamente pelo coordenador da gibiteca, Fábio Tatsubô, a cada ano, no dia que é comemorado o aniversário do equipamento, em dezembro, na presença de frequentadores, jornalistas, políticos, artistas e de dona Vilma, mãe de Marcel. No final das atividades de aniversário, os relatórios foram lidos, explicados e suas cópias foram disponibilizadas no local para que os visitantes pudessem levar.

Todos esses dados estão disponíveis no acervo para consulta dos visitantes e a versão atualizada dos dados de frequência da Gibiteca Municipal de Santos foi enviada pela atual coordenadora do local, Narayana Fida Mamede, no dia 10 de maio de 2018, como segue: 


\begin{tabular}{|c|c|c|c|}
\hline Ano & Atividade & Quantidade & № de participantes \\
\hline \multirow{5}{*}{2013} & Oficinas/Cursos & 17 & 70 \\
\hline & Visitas escolares & 22 & 440 \\
\hline & Visitas de leitores & & 4121 \\
\hline & Bate-papos/Exposições/Lançamentos & 59 & 387 \\
\hline & Total & 98 & 5018 \\
\hline \multirow{6}{*}{2014} & Atividade & Quantidade & № de participantes \\
\hline & Oficinas/Cursos & 9 & 110 \\
\hline & Visitas escolares & 23 & 760 \\
\hline & Visitas de leitores & & 4979 \\
\hline & Bate-papos/Exposições/Lançamentos & 76 & 667 \\
\hline & Total & 108 & 6516 \\
\hline \multirow{7}{*}{2015} & Atividade & Quantidade & № de participantes \\
\hline & Oficinas/Cursos & 13 & 125 \\
\hline & Visitas escolares & 5 & 87 \\
\hline & Visitas de leitores & & 2521 \\
\hline & Bate-papos/Exposições/Lançamentos & 88 & 1025 \\
\hline & Baú da Gibiteca & 09 & \\
\hline & Total & 115 & 3758 \\
\hline \multirow{7}{*}{2016} & Atividade & Quantidade & № de participantes \\
\hline & Oficinas/Cursos & 8 & 147 \\
\hline & Visitas escolares & 8 & 108 \\
\hline & Visitas de leitores & & 3813 \\
\hline & Bate-papos/Exposições/Lançamentos & 88 & 1297 \\
\hline & Baú da Gibiteca & 10 & \\
\hline & Total & 114 & 5365 \\
\hline
\end{tabular}




\section{ANEXO 2 - TABELAS DOS EVENTOS REALIZADOS POR DATA}

\section{Tipo de evento e data da realização}

\section{Apresentação}

As tabelas abaixo se baseiam no primeiro relatório enviado pela coordenação da Gibiteca. A divisão feita se refere exclusivamente ao tipo de evento realizado e não à quantidade considerada na primeira tabela com número de participantes, apresentada no Anexo I. Isso porque na primeira tabela, bate-papos realizados com artistas que também realizaram exposição de trabalhos e lançamentos no mesmo dia, foram contabilizadas no caderno de presença como um único evento.

Então, o objetivo destas tabelas é registrar os tipos de atividades realizadas e quem foram os convidados que já passaram pelo local entre os anos de 2013 e 2016. 


\begin{tabular}{|c|c|c|}
\hline & & 2013 \\
\hline ATIVIDADE & DATA & TíTULO \\
\hline \multirow{42}{*}{$\begin{array}{l}\text { BATE-PAPOS E } \\
\text { LANÇAMENTOS }\end{array}$} & $16 / \mathrm{fev}$ & Bate Papo com JAL \\
\hline & $31 / \mathrm{mar}$ & Culturalmente Santista - André Rittes e Alexandre BAR \\
\hline & $06 / a b r$ & Palestra - Os Trapalhões - Eduardo Vetillo, Alexandre Silva e Bira \\
\hline & 23/abr & Lançamento - Abaeté de Richard Dantas \\
\hline & 01/jun & Bate Papo com Alex Rezende \\
\hline & 07/jul & Mostra Superman e Bate Papo com Ivan Reis \\
\hline & 12/jul & Lançamento "Monstros" e Bate Papo Gustavo Duarte \\
\hline & 20/jul & 40 Anos de Morcego Vermelho \\
\hline & 27/jul & Bate Papo e sessão de autógrafos Marcatti \\
\hline & 10/ago & Lançamento HQ - Orçamento Participativo \\
\hline & 16/ago & Palestra - Na Semana da Juventude HQ e Drogas Andre Rittes \\
\hline & 17/ago & Debate Crowdfunding - Financiamento Colaborativo \\
\hline & 25/ago & Culturalmente Santista - Emílio Baraçal \\
\hline & 31/ago & Lançamento com Flávio Soares - A Vida com Logan \\
\hline & $05 /$ set & HQ Educativa "Menino Caranguejo" n¹ \\
\hline & $06 /$ set & Lançamento - Jazz com Alex Sander \\
\hline & $21 /$ set & Lançamento - De Quadro de Gilmar \\
\hline & 22/set & Lançamento - Vizinhos de Laerte Coutinho \\
\hline & 28/set & Debate de Mangá com Sonia Luyten e Cassius Medauar \\
\hline & 29/set & Culturalmente Santista de Paulo Ramos \\
\hline & 05/out & Lançamento - Fanzines - Lico Mota "Tropa de Heróis", \\
\hline & & Pipoca "Embrião", léio, Fabiano Geraldo e Thiago "Chroma" \\
\hline & 06/out & Bate Papo - HQ Independente e Zines com Laudo, Daniel Esteves \\
\hline & & Márcio Sno, e Lico Mota \\
\hline & 12/out & Fanzinada com Thina Curtis \\
\hline & & Bate Papo com Gazy Andraus - Dia Nacional do Fanzine \\
\hline & 13/out & Palestra "Zines ou Fanzines" com Gazy Andraus \\
\hline & & Debate - Produção Independente, Criação e Variadas \\
\hline & & Manifestações Artísticas através dos Fanzines - Thina Curtis, \\
\hline & & $\begin{array}{l}\text { Fabiano Geraldo e Thiago Goma } \\
\end{array}$ \\
\hline & 19/out & Debate Acadêmico - Utilização do Fanzine na Sala de Aula com \\
\hline & & Ana Basaglia, Sabrina Paixão, Renata Barrocas e Gazy Andraus \\
\hline & & Lanç. Coletivo com lan Cichetto, Rodrigo Motta, \\
\hline & & Marcatti, Lico Mota e Worney (AQC 100) \\
\hline & 20/out & Debate Acadêmico - Utilização do Fanzine na Sala de Aula com \\
\hline & & Renato Donizete, Adriane Almeida Pintos e Gazy Andraus \\
\hline & $06 /$ nov & Contação de Histórias com Camila Genaro \\
\hline & $13 /$ nov & Contação de Histórias com Camila Genaro \\
\hline & $21 /$ nov & Lançamento HQ Educativo - Menino Caranguejo no2 \\
\hline & & Contação de Histórias com Camila Genaro \\
\hline & $23 /$ nov & Debate Mangá - Denis Dym e Leandro Altafim \\
\hline & 27/nov & Lançamento HQ Educativo - Menino Caranguejo no3 \\
\hline
\end{tabular}




\begin{tabular}{|c|c|c|}
\hline & & Contação de Histórias com Camila Genaro \\
\hline & $28 /$ nov & Lançamento HQ Educativo - Menino Caranguejo no4 \\
\hline & $29 /$ nov & Lançamento HQ Educativo - Menino Caranguejo no5 \\
\hline & 04/dez & Contação de Histórias com Camila Genaro \\
\hline & 08/dez & Bate Papo com Fábio Coala \\
\hline & & Bate Papo - HQ Independente com Victor Freundt, Bruno Bispo, \\
\hline & & Kiko Garcia, André Alonso e Sônia Bibe Luyten \\
\hline & & Bate Papo e sessão de Autógrafos com Victor Cafaggi \\
\hline & $11 /$ dez & Contação de Histórias com Camila Genaro \\
\hline & 18/dez & Contação de Histórias com Camila Genaro \\
\hline \multirow{12}{*}{ EXPOSIÇÕES } & $16 /$ fev & JAL \\
\hline & $06 / a b r$ & Os Trapalhões \\
\hline & $18 /$ mai & Coleção Educar e Conciência \\
\hline & 27/jul & Marcatti \\
\hline & 24/ago & Mangá e Folclore \\
\hline & $14 /$ set & O Mundo Imaginário de Nice \\
\hline & 05/out & Fanzines - Expo Coletiva \\
\hline & 26/out & Escola Oficina \\
\hline & $22 /$ nov & Ilustrações de Weberson Santiago \\
\hline & 12/out & Dia Nacional do Fanzine \\
\hline & $08 / \mathrm{nov}$ & Encontro Quadrinhos Institucionais \\
\hline & $15 /$ nov & Culturalmente Santista \\
\hline \multirow{5}{*}{ EVENTOS GEEK } & $01 /$ set & Encontro de Jogos de Tabuleiro e Cards - Galápagos Jogos \\
\hline & $03 /$ nov & RPG 4 ALL + Cosplay \\
\hline & $09 /$ nov & Cultura POP Japonesa - Animês \\
\hline & $10 /$ nov & Cultura POP Japonesa - Tokusatsus \\
\hline & $07 / \mathrm{dez}$ & Participação na Primeira Santos Comic Com \\
\hline
\end{tabular}




\begin{tabular}{|c|c|c|}
\hline & & 2014 \\
\hline ATIVIDADE & DATA & TíTULO \\
\hline \multirow{11}{*}{$\begin{array}{l}\text { BATE-PAPOS E } \\
\text { LANÇAMENTOS }\end{array}$} & $15 / \mathrm{fev}$ & Vency's Lao, Mario Cau e Digo Freitas \\
\hline & $08 / \mathrm{mar}$ & Debate Lançamento - Dia da Mulher \\
\hline & $22 /$ mar & Encontro do Ovelha Negra - Geandré, Fausto e Da Costa \\
\hline & 29/mar & Lançamento Marcatti, Flávio Luiz e Daniel Esteves \\
\hline & 12/abr & Lançamento Gibi Quântico e Jones Inc \\
\hline & 26/abr & \begin{tabular}{|c|} 
Bate Papo Mangá Montserrat Montse \\
\end{tabular} \\
\hline & $17 /$ mai & Bate Papo e Lançamento Laudo, Flávio Soares e Clayton Inloco \\
\hline & 02/set & Contação de Histórias \\
\hline & 12/out & Dia Nacional do Fanzine \\
\hline & $08 /$ nov & Encontro Quadrinhos Institucionais \\
\hline & $15 /$ nov & Culturalmente Santista \\
\hline \multirow{13}{*}{ EXPOSIÇÕES } & 04/jan & História dos Quadrinhos Nacionais \\
\hline & 30/jan & Mostra Caiçara \\
\hline & $22 / \mathrm{fev}$ & Calazans \\
\hline & $15 / \mathrm{mar}$ & Wagner Rocha \\
\hline & 08/abr & Da Turma da Cidadania - Gibi Institucional \\
\hline & 15/abr & Dia do Desenhista \\
\hline & 09/mai & Thundercats por uns 30 \\
\hline & $31 / \mathrm{mai}$ & Icones da Cultura pop Mexicana \\
\hline & 27/jun & Élcio Prado \\
\hline & $19 /$ jul & Street Fighter \\
\hline & 15/ago & Messias de Melo \\
\hline & $13 /$ set & Da Costa \\
\hline & 11/out & Santistas que Brilham \\
\hline \multirow{15}{*}{ EVENTOS GEEK } & 18/jan & Animelan Project \\
\hline & $23 / \mathrm{fev}$ & Animelan \\
\hline & $09 / \mathrm{mar}$ & RPG_4 - All 2 \\
\hline & 06/abr & Animelan Project \\
\hline & $18 / \mathrm{mai}$ & Animelan \\
\hline & 08/jun & RPG_4 - All 3 \\
\hline & 29/jun & Animelan \\
\hline & 20/jul & Animelan \\
\hline & 24/ago & Animelan \\
\hline & $06 /$ set & Nerd Cine Festival \\
\hline & $07 /$ set & Nerd Cine Festival \\
\hline & 08/set & Nerd Cine Festival \\
\hline & 21/set & Animelan \\
\hline & 19/out & RPG_4 - All 4 \\
\hline & $30 /$ nov & Animelan \\
\hline
\end{tabular}




\begin{tabular}{|c|c|c|}
\hline & & 2015 \\
\hline ATIVIDADE & DATA & TíTULO \\
\hline \multirow{30}{*}{$\begin{array}{l}\text { BATE-PAPOS E } \\
\text { LANÇAMENTOS }\end{array}$} & $28 / \mathrm{fev}$ & Encontro PROAC (Miss) \\
\hline & $21 /$ mar & Lanç. Col. Marcatti, Thiago Souto, Kiko, Laudo e Flavio Soares \\
\hline & $25 / a b r$ & Bate Papo com Desenvolvedores de Games (Posto 6) \\
\hline & 26/abr & Bate Papo - Estação da Cidadania Davi Colil, Arthur, Jr Couto, \\
\hline & \multicolumn{2}{|r|}{ Julia Bax, Eder Messias e Fujita. } \\
\hline & 23/mai & Bate Papo e autógrafos - Rafael Coutinho-Estação da Cidadania \\
\hline & 27/jun & Coletiva Thiago Souto, Adilson Reis e Guilherme Infante \\
\hline & 28/jun & Bate Papo - Bianca Reis \\
\hline & 16/jul & Bate Papo Nobohiro Watsuki \\
\hline & 26/jul & Coletiva Lucila Saidenberg, Seri e Paulo Mathia \\
\hline & 16/ago & Lançamento HQUÊ \\
\hline & 30/ago & Col. Caeto Melo, Rafael Marcely, Tiago, Judas e Renato Machado \\
\hline & $16 /$ set & Bate Papo Kickante - Viviane Sedola e Marcus Vinicius Batista \\
\hline & $19 /$ set & BP Desenho de Horror e Mercado \\
\hline & $19 /$ set & HQ's e Educação - Calazans, Davi, Lindenberg, \\
\hline & & Viviane Veiga e Andrea Cunha. \\
\hline & 26/set & Bate Papo Editores de HQ - Fernando Lopes e Editores da "Mino" \\
\hline & 27/set & Bate Papo e Lanc. Felipe Neve, André Freitas e Danyael Lopes \\
\hline & 16/out & Bate Papo Fanzine e sua Transposição Mediática e Meditataiva \\
\hline & 17/out & Dia Nacional do Fanzine Grazy Andraus \\
\hline & 18/out & Bate Papo - 50 anos do Lançamento do Zine "Ficção" \\
\hline & 24/out & Bate Papo - Calazans, Valdir Alvarenga e Luiz Autório \\
\hline & $14 /$ nov & Culturalmente Santista \\
\hline & $21 /$ nov & Edgar Franco - Palestra processos criativos de Quadrinhos \\
\hline & & Filosófico (mediação Gazi Andraus) \\
\hline & $21 /$ nov & Lançamento do Album Retrogênese \\
\hline & 23/nov & Bate Papo com Cartunista Gonzales \\
\hline & 28/nov & Bate Papo - Fernando Gonsales \\
\hline & 11/dez & Bate Papo - AQC \\
\hline & 11/dez & Lançamento HQs Independentes \\
\hline \multirow{9}{*}{ EXPOSIÇÕES } & 12/jan & Deodato Borges \\
\hline & 27/jun & Moacir Jones e Cine Comunidade \\
\hline & 16/jul & Samurai $\mathbf{X}$ \\
\hline & 16/ago & Hurulla \\
\hline & $04 /$ set & Alunos do Curso de Mangá \\
\hline & 12/out & Capas Históricas dos Zines "Barata e Mirante" \\
\hline & 07/nov & Erradicação do Trabalho Infantil - Ed Carlos \\
\hline & $01 / \mathrm{dez}$ & Naruto \\
\hline & 12/dez & Maurício de Souza \\
\hline & 18/jan & Animelan Summer Edition \\
\hline & $22 /$ fev & Animelan (MISS) \\
\hline & 22/mar & Animelan Z.N. - Puuunch Edition \\
\hline
\end{tabular}




\begin{tabular}{|c|c|c|}
\hline \multirow{23}{*}{ EVENTOS GEEK } & $28 /$ mar & 1 TOB (CAIS) \\
\hline & $11 / a b r$ & $2^{\circ}$ TOB (CAIS) \\
\hline & $24 /$ mai & Animelan Estação Cidadania \\
\hline & 13/jun & 3ㅇ TOB \\
\hline & 28/jun & Animelan \\
\hline & $05 /$ jul & 1 Coffe and Draw \\
\hline & 18/jul & Cine Anime - Samurai $x$ \\
\hline & 19/jul & 1 RPG Day \\
\hline & $25 /$ jul & Game Fest \\
\hline & 16/ago & 2ㅇ Coffe and Draw \\
\hline & 23/ago & 2ㅇ RPG Day \\
\hline & $20 /$ set & 2 Game Fest \\
\hline & $27 /$ set & 3 Coffe And Draw \\
\hline & 04/out & Animelan \\
\hline & 10/out & 3 Game Fest \\
\hline & 25/out & 3 RPG e TOB + Caverna do Dragão \\
\hline & 07/nov & Teatro de Cosplay \\
\hline & $15 /$ nov & 4 Coffe and Draw \\
\hline & 22/nov & Animelan \\
\hline & $29 /$ nov & 4으 RPG Day e TOB + Cverna do Dragão \\
\hline & 12/dez & Sketchcrawl \\
\hline & 12/dez & Caricatoon \\
\hline & 13/dez & TOB + X-Wing \\
\hline
\end{tabular}




\begin{tabular}{|c|c|c|}
\hline & & 2016 \\
\hline ATIVIDADE & DATA & TíTULO \\
\hline \multirow{27}{*}{$\begin{array}{l}\text { BATE-PAPOS E } \\
\text { LANÇAMENTOS }\end{array}$} & 23/jan & Bate Papo João Carpalhau \\
\hline & $20 /$ fev & Lanç. Coletivo Felipe Cagno, Eric Peleiras e André Bernardino \\
\hline & $27 / \mathrm{fev}$ & Lançamento Coletivo Café Espacial \\
\hline & $05 / \mathrm{mar}$ & Bate Papo Mulheres nos Quadrinhos \\
\hline & $16 / a b r$ & Lançamento Marcatti e Victor Freudt \\
\hline & $07 / \mathrm{mai}$ & Lançamento Histórias: Batman e Superman no Cinema \\
\hline & 14/mai & Super Heróis- Gabriel França, Marco Aurélio e Emílio Baraçal \\
\hline & $15 /$ mai & Lançamento CB Gibi \\
\hline & 29/mai & Lançamento Vudu \\
\hline & 25/jun & Lançamento Miolo Frito \\
\hline & 26/jun & Mercado Internacional de Quadrinhos \\
\hline & 02/jul & Debate - A Importância da Contação de História com \\
\hline & & Camila Genaro e Eliane Greco \\
\hline & 03/jul & Leia Santos na Gibiteca \\
\hline & 17/jul & Debate Cosplay - Alexandre Bar, Juliana Vita e Zelito Oliveira \\
\hline & 23/jul & Lançamento Coletivo Flávio Soares e Fábio Cicone \\
\hline & 30/jul & Lançamento "Meu pai vai me buscar na escola" \\
\hline & 13/ago & Coletânea Feminina de Quadrinhos \\
\hline & 20/ago & Debate Limites do Humor - Dani Marino e Grazi Andraus \\
\hline & 27/ago & Debate Web Comics - Produção de Quadrinhos na Internert \\
\hline & $04 /$ set & Discussão DC X Marvel \\
\hline & 09/out & Palestra Edson Rontani Jr \\
\hline & 29/out & Lanç. Gibio \#16 - Gazy Andraus Lançamento Marcio Sno \\
\hline & 30/out & Bate Papo Terror - Raphael Fernandes \\
\hline & $05 /$ nov & Bate Papo Quadrinheiros - Os Dois lados da Guerra Civil \\
\hline & $12 /$ nov & Bate Papo Quadriculando \\
\hline & $19 /$ nov & Bate Papo Jazz Miranda, BAR, Avalone e Mauro de Abreu \\
\hline \multirow{15}{*}{ EXPOSIÇÕES } & 03/jan & Star Wars \\
\hline & 05/jan & Charges do D.O - Caruara \\
\hline & 23/jan & Carlos Avalone \\
\hline & $13 /$ fev & Brasil - Africa - AQC \\
\hline & $08 / \mathrm{mar}$ & Homenagem a Maurício de Souza (Caruara) \\
\hline & 20/mar & Brasil - Paraguai - AQC \\
\hline & 17/abr & Clayton Inloco e Victor Freundt \\
\hline & $31 / \mathrm{jul}$ & Filmes com RC Studio \\
\hline & $17 /$ set & Gibi Quântico II \\
\hline & 09/out & Erico San Juan \\
\hline & 15/out & Márcia Okida e Mila Queiroz \\
\hline & $05 /$ nov & Augusto Passos \\
\hline & $19 /$ nov & Receptação é Crime \\
\hline & $26 /$ nov & Quadro à Quadro \\
\hline & 03/jan & Game Fest \\
\hline
\end{tabular}




\begin{tabular}{|c|c|c|}
\hline \multirow{18}{*}{ EVENTOS GEEK } & 17/jan & Table Top Day \\
\hline & $14 / \mathrm{fev}$ & Table Top Day \\
\hline & $28 / \mathrm{fev}$ & Animelan \\
\hline & $13 /$ mar & Table Top Day \\
\hline & $17 / a b r$ & Coffe and Draw - BAR \\
\hline & $30 / a b r$ & Table Top Day \\
\hline & $01 /$ mai & Table Top Day - X-Wing \\
\hline & 22/mai & Coffe and Draw - Clayton Inloco \\
\hline & 29/mai & Table Top Day \\
\hline & 30/mai & Table Top Day - X-Wing \\
\hline & 19/jun & Table Top Day - Battle Scenes e Magic \\
\hline & 26/jun & Coffe and Draw Leandro Altafim e Mangarts \\
\hline & 24/jul & Coffe and Draw Alex Ponciano \\
\hline & $31 /$ jul & Table Top Day \\
\hline & 21/ago & Coffe and Draw RC Studio \\
\hline & 28/ago & Table Top Day \\
\hline & $24 /$ set & Geek Fest \\
\hline & $25 /$ set & Coffe and Draw \\
\hline
\end{tabular}


APÊNDICES - QUESTIONÁRIOS, DEPOIMENTOS E DADOS DAS GIBITECAS MENCIONADAS 


\section{APÊNDICE A - QUESTIONÁRIO}

\section{Questionário online realizado com frequentadores da Gibiteca Municipal de Santos}

\section{Apresentação}

O Questionário online ficou disponível entre os meses de agosto de 2017 e maio de 2018, via ferramenta do Google Docs. O formulário foi disponibilizado em duas páginas do Facebook formadas por frequentadores da Gibiteca e até o momento da confecção da dissertação, 21 pessoas haviam respondido às perguntas.

Como a pesquisa se baseia em um estudo de caso com participação e observação da autora nos eventos ocorridos na Gibiteca, muitas perguntas e interações com os visitantes já haviam sido feitas anteriormente à formalização da dissertação, ainda que informalmente. Já em relação ao questionário, seu principal objetivo é de ilustrar algumas considerações feitas por Pustz (2000) e Wright (2008) quanto aos fatores que levariam fãs e leitores de histórias em quadrinhos a se agruparem e frequentarem eventos relacionados aos temas que costumam consumir em suas revistas.

Assim, ainda que o questionário sozinho não seja capaz de indicar as tendências de todos os frequentadores da Gibiteca, o que se busca com a interpretação das respostas obtidas é apontar se a amostra coletada pode corroborar os autores elencados na pesquisa em relação à importância da realização dos eventos presenciais sobre histórias em quadrinhos, verificando assim, de que forma os visitantes da gibiteca são afetados por esses eventos.

As respostas encontram-se agrupadas por questão: 
Pergunta 1 - Qual é a sua idade, sexo (gênero) e profissão?

29 , masculino, Vigia e organizador de eventos

34, masculino, Videomaker e Fotógrafo

36 ,masculino,designer

28, Feminino, Ilustradora

34 , masculino, professor de artes visuais

33, masculino, designer

44 , masculino, jornalista

Trinta e nove, feminino e professora

39 , masculino, desenhista

26 , feminino, designer e ilustradora

56 anos, Masculino, Professor - Artista plástico - Quadrinista

18,sexo masculino,nenhuma profissão ainda!

18 anos, feminino,estudante

37 anos, masculino, jornalista

35 , masculino, professor

19 anos, masculino , técnico em nutrição

37, masculino, comerciante

22 , feminino, auxiliar administrativo

23, homem, publicitário

57 anos , masculino, artista plastico e quadrinista

56 anos, masculino, porteiro 
Pergunta 2 - Há quanto tempo frequenta a Gibiteca?

Há quanto tempo frequenta a gibiteca?

21 respostas

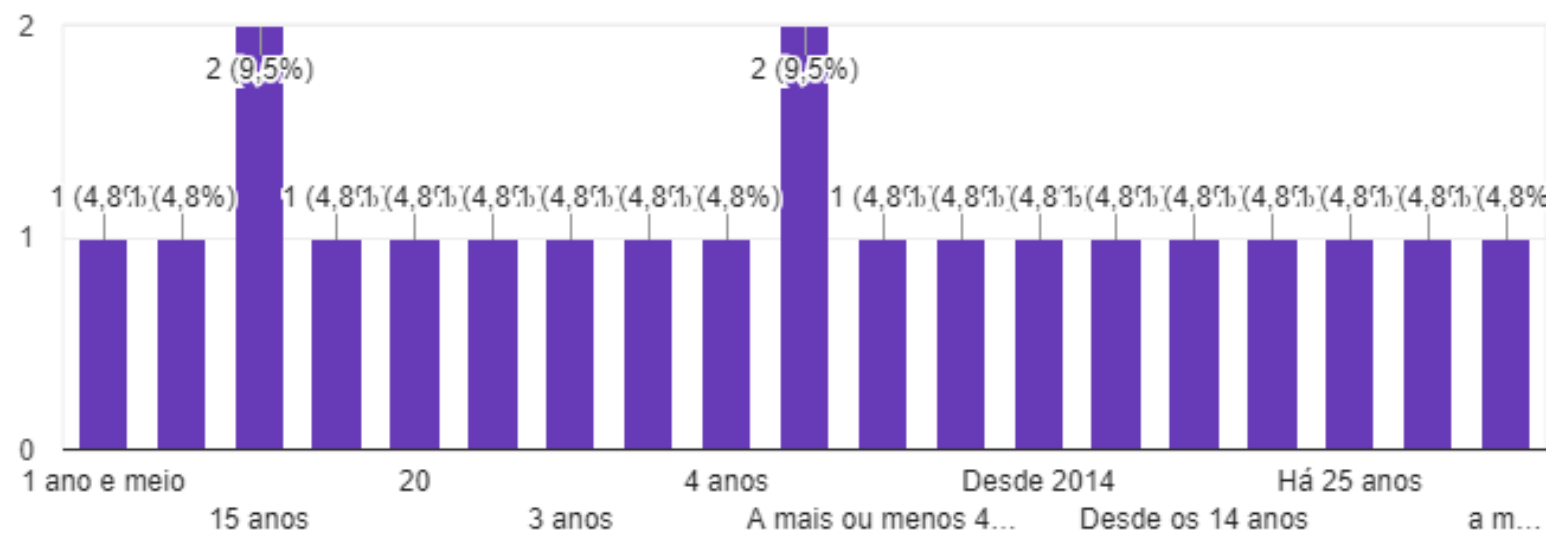

Pergunta 3 - Com que frequência costuma participar dos eventos realizados lá?

Com que frequência costuma participar dos eventos realizados lá? 21 respostas

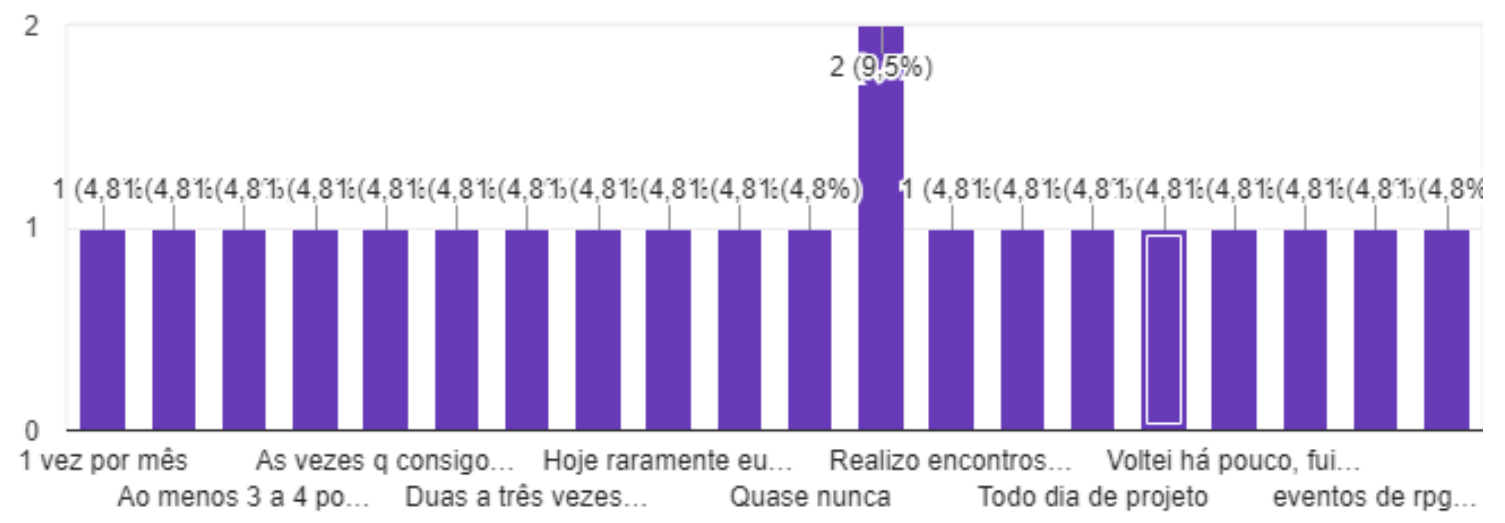


Pergunta 4 - Você costuma ler quadrinhos na gibiteca? Que tipo de quadrinhos?

Você costuma ler quadrinhos na gibiteca? Que tipos de quadrinhos?

Não com frequência,mas quando leio são os clássicos do homem aranha (2)

Quando vou levo minhas filhas que leem, jogo boardgame e rpg (2)

Marvel, Image, relacionados a RPG, mangás, livros Jogos.

Já li muitos. Li Sandman, meu favorito, e até hoje não comprei pra minha coleção, porque sei que encontro na Gibiteca. Normalmente, leio o que não encontro em casa.

Heróis e revistas informativas

mangás, HQs da Marvel alguns da DC (não nego sou marvete), turma da Mônica.

Sim. De super heróis.

Sim. Os independentes.

os independentes

Sim, mangás

Não, mas meus filhos sim, infantis

Sim. Hqs de heróis como The Flash, Homem Aranha e etc.

Frequento a Gibiteca nos eventos, prestigiar as festas e dando palestras ou participando dos bate-papos.

Eu adoro mangas e leio quando estou com o tempo livre...

Sim. Super Heróis.

Quadrinhos antigos

Não

Sim, mangás e quadrinhos autorais

Não costumo ler quadrinhos lá

Só vou em eventos !

HQs que não conhecia ainda. 


\section{Pergunta 5 - O que o leva a ler uma HQ na gibiteca? Quais as principais vantagens em ter acesso gratuito aos quadrinhos?}

\section{O que o leva a ler uma HQ na gibiteca? Quais as principais vantagens em ter acesso gratuito aos quadrinhos?}

22 respostas

Você pode ler simplesmente quantas vezes quiser e tem uma enorme variedade de outros quadrinhos (2)

Em casa somos 3 que gostam de hq, então na gibiteca tem para todos os gostos (2)

Um ambiente que é bem aceito e pode achar pessoas que também curtem o mesmo hobby que o seu.

O fato de estar no "quintal de casa". As vantagens são várias, mas a melhor é poder ler algo que ainda não li antes de comprar.

Diversidade e qualidade além de fácil acesso

Para mim acho que o ambiente super descontraído e confortável, a gratuidade, é um espaço até legal para desenhar, e pegar algumas referências. Já acho que para o público é muito legal essa idéia, de um cantinho para ler quadrinhos, onde tem palestras, e até cursos, muito legal não só legal para quem somente gosta ou é fã, bom para que as pessoas ter mais conhecimento desse mundo, e para aqueles que não podem adquirir um quadrinho hoje em dia, pode chegar lá e ter esse prazer especialmente a motivação da leitura para todos.

Quero me inserir mais profundamente ao universo que a hq me oferece. As vantagens, de ler raridades que jamais teria acesso, principalemente por não morar em Santos

Algum quadrinho q nao comprei e sempre quis.ver em minhas mãos.. A vantagem eh poder registrar na mente tudo aquilo q nao se comprou! :)

conhecer novos autores

Variedade de títulos e a sequência dos números

Justamente, é um espaço gratuito onde é possível ler e discutir com outras pessoas sobre os mesmos interesses.

Faço troca e já fiz doações de Gibis. Acredito que acesso gratuito é muito importante e impressindivel para quem não tem condições de adquirir!

Eu adoro ler meus mangas prediletos e não tenho dinheiro para compra-los então ajuda muito

Muitas opções de leitura

Conhecer materiais antigos e publicações independentes

Variedades

Melhor qualidade de leitura e sustentabilidade

Eu frequento mais pelos ilustradores

A vantagem é ler coisas diferentes que não tenho ou não preciso comprar por poder ler lá!!

A variedade é grande, mas merece um espaço maior. Você descobre algumas histórias que valem a pena comprar quando puder. Mas, acho que só deveriam emprestar as repetidas 


\section{Pergunta 6 - Como você avalia o acervo disponível?}

\section{Como você avalia o acervo disponível?}

Um acervo Muito bom com ótimos cuidados, bem separados e fáceis de achar o que quer ler

O acervo da gibiteca é imenso e é bastante satisfatório. Talvez faltem encadernados de quadrinhos clássicos, para a "doutrinação" dos mais jovens e para que novos leitores entendam melhor a arte quadrinhos sem preconceitos.

Ótimo

Bom, faz um tempo que não vou lá, pelo que eu conheço, acho que falta um pouco de mais atuais e quadrinhos e histórias de ilustradoras e ilustradores autônomos, mesmo não conhecidos...

Completo

Muito bom e cada vez melhor.

o acervo é bom

Muito bom

Excelente

Bom

Eclético

nota 10 até agora...

$90 / 100$

Incrivel e extremamente vasto e bem conservado

Bom. Mas mal conservado

Excelente

Tem bastante coisa lá, mas faltam alguns "clássicos" que deveriam ter, uma nota 7

Otimo

Gigantesco

Variado e bom!

Bem variado. Só que precisa de mais espaço 


\section{Pergunta 7 - Por que os eventos realizados são importantes?}

\section{Por que os eventos realizados são importantes?}

Para promover o conteúdo que muitas vezes é desconhecido pela maioria da população (2)

Para difundir a leitura, minhas filhas tem 8 e 10 anos, costumam ler em casa, mas o ambiente da gibiteca faz com que elas queiram consumir cada vez mais, melhorando a leitura (2)

Para atrair mais público, conhecimento e espalhar os hobbys das tribos urbanas

Para a divulgação de artistas independentes, para o desenvolvimento de uma cultura de quadrinhos nacionais, para aumentar o interesse de jovens e para a atração de novos eleitores, sem contar na disseminação do conhecimento da existência da Gibiteca para os mais "desligados".

Socialização e apresentação de conteúdo aos visitantes, tanto jovens como adultos

Para divulgação da própria gibiteca, e conhecimento da população - eu por exemplo, fui conhecer e vizitar a gibiteca em 2014, a partir daí conheci muitos amigos, reencontrei amigos de velha data...

Sem contar que é um ótimo ambiente pra socializar, não só para adultos, mas crianças, jovens idosos em geral!

Para unir o novo ao antigo em práticas de leitura, principalmente com a variedade de eventos realizados.

Para conseguir mais adeptos tabm

porque integra autores com os fãs e troca de informação

Para divulgar o espaço e as atividades

Além do incentivo ao hábito da leitura, os eventos promovem artistas da região e fomentam a cultura

Para mostrar a importância da leitura de quadrinhos na região, agrega conhecimento com os cursos e palestras, faz com que as pessoas socializem mais entre si.

Para dar oportunidade do Fã de participar e conhecer pessoas da área, e estar mais intereada com o mundo dos quadrinhos ou mesmo dos rpgs.

Ajudam a socialização de muitos dos quais gostam de coisas do tipo...

Para levar mais gente para dentro da gibiteca.

Porque é o único espaço de divulgação de material nacional em Santos além de ser a única oportunidade de algumas pessoas poderem fazer cursos gratuitos na área de quadrinhos em Santos

Para interação social

Para dar mais visibilidade e publico para a gibiteca

Visibilidade, seriedade é compromisso com a arte no Brasil

Para o aprendizado e contato com quem faz quadrinhos !

Pelo visto só são importantes pra quem faz. A maioria dos defensores da gibiteca quase nunca está lá 
Pergunta 8 - Já participou de algum curso ministrado na Gibiteca? Quais?

\section{Já participou de algum curso ministrado na Gibiteca? Quais?}

Não (4)

Ainda não, mas tenho interesse (2)

Não (2)

Curso de desenho

Sim. Criação de Personagens, pelo José Jr., quando eu ainda era adolescente.

Ainda não

Sim claro, Desenho/ quadrinhos (RB Silva), Pintura (Art Helton), Roteiro (Alexandre Bar) - eu só não me recordo exatamente dos tema (desculpe)

Sim. Desenho

Varios.. Hq , arte final, mangá.

sim, noções básicas de quadrinhos

Palestras e desfile de Cosplays

não

Sim. Roteiro.

Não!

Nunca mas já pensei em participar

Já quando era mais novo. Desenho e mangá

Sim, curso de Mangá

Roteiro - Alexandre bar, anatomia básica de super heróis - RB silva e pintura com lápis de cor -helton soares 


\section{Pergunta 9 - Caso tenha participado de cursos, como eles contribuíram para a sua formação? Você atua como artista na área de quadrinhos?}

\section{Caso tenha participado de cursos, como eles contribuíram para a sua formação? Você atua como artista na área de quadrinhos?}

Nunca participei (2)

Ainda não participei de nenhum curso, mas escrevo histórias por hobby e as contos em mesas de rpg (2)

Sou mestre e organizador de RPG na Gibiteca, ajuda a conseguir mais conhecimento e espalhar para quem quer aprender ou conhecer.

O curso que eu fiz só aumentou meu interesse pelos quadrinhos, ajudou na minha formação como artista, incluindo na tomada de decisão pela minha carreira. Eu desenho, mas nunca publiquei. Estou produzindo um projeto de publicação online.

Poorra, olha para começar, ao conheçer, amigos, pessoas do ramo no qual admiro desde pequena (desenhistas e etc), a gibiteca foi um dos impulsos e motivação em relação a minha profissão, por isso também entrei na faculdade, estou cursando Designer gráfico (ESAMC santos) além do estudo me expandir os horizontes, todos estes amigos ilustradores, professores e etc ajudaram com esse estímulo, diante ao mercado, pois desanima muito, juntando com o que a sociedade impõe, no caso de nós mulheres, tirando o fato do reconhecimento profissional que ilustradores enfrentam, e a dúvida de fazer o que quer ou se sustentar ... É difícil, mas por isso que um espaço desse é importante, formando e motivando futuras e futuros ilustradores, quadrinistas e etc.

Eles me deram dicar valiosas para o traço em meus desenhos. Minha atuação hoje é o apresentar de ferramentas digitais e complementares aos desenhos de quadrinhos.

Me.ajudaram de alguma forma dentro do meu trabalho! Sim atuo com ilustração freelancer.

foi a porta de entrada para todo o segmento de quadrinhos

Sou público

sim, sou desenhista

Sim. Tem me ajudado muito na construção de roteiros para Hq. Inclusive o fato de ir la faz com que eu me encontre com outros artistas que me dão dicas e pequenas "aulas" importantes pro meu aprendizado como artista.

Eu adoraria ajudar a escrever um... Eu sou um pequeno iniciante a escritor e isso seria até um grande passo para algo mais profundo por assim dizer... Mas nunca participei de nenhum curso...

Conheci pessoas q me influenciaram a seguir esse caminho dos quadrinhos.

Ainda não atuo como profissional por opção pessoal

Sempre é bom renovar oque já sabemos, fiz muitos amigos e parcerias porém sou muito procastinador com meus projetos em quadrinhos, mas pretendo trabalhar sim nessa área

Não atuo na área, infelizmente 


\section{APENDICE B - DEPOIMENTOS}

\section{Apresentação}

Os depoimentos de Alexandre Alves Valença Barbosa e Osvaldo da Costa são significativos no sentido de fornecer informações e considerações de pessoas que não só estiveram presentes nos principais momentos da vida da Gibiteca ao longo de seus 25 anos, como também conheceram pessoalmente Marcel Rodigues Paes, além de terem colaborado com jornais locais com matérias e cartuns relacionados ao cotidiano da cidade e da própria Gibiteca.

\section{Alexandre Alves Valença Barbosa - "Bar"}

Texto sobre a minha relação com a Gibiteca Marcel Rodrigues Paes.

Minha relação com a Gibiteca vem de antes de sua criação. O jornalista Marcel Rodrigues Paes, que dá o nome aquele espaço, estudou comigo na Universidade e trabalhamos juntos no jornal Tribuna durante anos.

Marcel sempre quis entrar no universo dos quadrinhos, e na época de faculdade em 1987, ele escrevia diversos roteiros. Chegou a mostrar-me alguns, em particular lembrome de um que faríamos juntos, mas nunca chegou a concluir.

Gostava muito de quadrinhos e colecionava não só as revistas, como também artigos que falavam a respeito de quadrinhos. Na Tribuna conseguiu espaço para escrever uma coluna sobre histórias em quadrinhos e tudo que as cercava. Muitas vezes trocávamos informações sobre isto, porque ele sabia o quanto eu também gostava.

Após a sua doença e o falecimento em 1992, a coluna de história em quadrinhos ficou a cargo de Sérgio Ribeiro Lemos, o Seri, que depois de um tempo desistiu de escrevêla. Foi neste momento que eu assumi a coluna que era de Marcel.

Quando o caderno para o seguimento jovem foi criado, o Tribu, a coluna migrou das páginas de variedades para este. Lá o nome da coluna mudou e passou a se chamar Balão do Bar.

Eu seguia a mesma linha que Marcel criara e tentava falar não só das novidades produzidas nas grande editoras, como também das produções nacionais e dos fanzines.

Neste tempo surgiu a Gibiteca, e nós estávamos lá, eu, Seri, Gazy, Calazans... e muitos outros artistas que víamos um desejo se realizar. Tive o prazer de fazer o primeiro desenho que recepcionava os visitantes na entrada daquele espaço, o mesmo desenho que ilustrou a matéria publicada na Tribuna que homenageou o trabalho de Marcel como jornalista e fã de quadrinhos. 
Todos nós já conhecíamos a Gibiteca Henfil em São Paulo e queríamos algo assim. $\mathrm{Na}$ época lembro de alguns artistas reclamando da localização, do perigo da maresia, do espaço apertado. Mas tudo isto ficou para trás e ela está aí, atendendo aos fãs dos quadrinhos até hoje.

Vários desenhistas que participaram com suas exposições na Gibiteca foram até o jornal para uma nota na coluna. Eu sempre incentivei os novos artistas com um texto mostrando importância de prestigiá-los. Um deste casos foi Fábio Yabu.

O artista responsável por Combo Rangers e Princesas do Mar era um adolescente quando trouxe seus primeiros trabalhos. Outro artista que mostrou seus trabalhos para nós foi Fábio Coala, responsável pelos livros Monstro e Mentirinhas.

Mesmo depois de sair do jornal em março de 2002, mantive contato com a administração da Gibiteca e sempre procurei manter esta relação, através de palestras, exposições e participando de atividades promovidas por outros artistas.

Ainda hoje ajudo a promover os eventos e participo sempre que posso, pois sei da importância deste espaço como formador de fãs e produtores de histórias em quadrinhos.

\section{Depoimento de Osvaldo da Costa - enviado por e-mail}

\section{Gênero menor, aonde?!}

Nas margens do Oceano Atlântico próximo da cidade mais velha do Brasil, os primeiros colonos nunca imaginaram, isso em 1532, que leituras de histórias ilustradas encontraria um porto seguro. Pode ser uma nova estória sobre o povoamento e seus hábitos de leituras, talvez, não tenha chego exemplares de Portugal as margens do oceano. Em 1546, os primeiros moradores do município portuário, a vila de Santos, só conheciam a história ilustrada nos livros sacros ou afrescos das capelas? A paixão de Cristo e suas 14 estações com "texto em off", era a "Hqs" sem o baloon dos diálogos?!

Na baia da cidade de Santos os "Cosplay" dos personagens "Star Trek", "Star Wars", "Anime"... etc, caminham ao redor do maior jardim na orla da praia. Nas margens do Atlântico a casa dos desenhistas, roteiristas, criadores, produtores, colecionadores, leitores, apaixonados, estudantes, professores, interessados, famílias. Ela é frequentada e desfrutada por moradores e visitantes que procuram por farta leitura de histórias ilustradas. Como será a convivência de pessoas em um ambiente de leitura conhecida como um gênero menor. Hoje ela tem eventos, contação de histórias infantis, lançamentos de revistas, bate-papos com artistas nacionais. Cursos de desenho e oficinas artísticas mais próximo da população.

Uma das primeiras visitas que fiz a Gibiteca foi numa palestra da prof. Sonia Luyten, sobre a arte sequencial, com muito entusiasmo, ela nos falava sobre a produção de Hqs no Japão e o interesse dos japoneses por Hqs brasileiras. O que é Mangá era a pergunta que se fazia no encontro. Era final de tarde, foi dada a palavra, como estava e andava a produção de quadrinhos no Brasil. Participei de alguns encontros sobre desenho, humor gráfico, exposições de cartuns e charges. A 
arte e a filosofia da contra cultura na obra do cartunista Glauco, foi um preâmbulo de um texto abandonado na gaveta. Apresentei nesse encontro, o um resumo da origem do humor, comportamento e contestação num período pós-ditadura na obra do cartunista.

Quando ministrei oficinas de encadernação do livro de esboço, técnica aquarela e desenho de paisagem, conheci outras faces. Aproximando-se da população local você conhece outro perfil da cidade. Outros artista que trazem experiências nas sua áreas de atuação alimentam futuros artistas visuais, desenhistas, roteiristas, criadores, produtores, colecionadores, leitores, apaixonados, estudantes, professores, interessados, famílias.

Uma vila, um bairro, um município, um estado, um país é sempre reconhecido por um filho ilustre e a Gibiteca, - inaugurado no governo Telma de Souza, administração que e tirou a cidade de Santos do obscurantismo da ditadura - tem como patrono o santista de nascimento Marcel Rodrigues Paes, jornalista e especialista, apaixonado por Histórias em Quadrinhos ou "HQs".

Vida Longa e próspera a $9^{\mathrm{a}}$ Arte, a Histórias em quadrinhos, nas margens do oceano Atlântico, os primeiros colonos nunca imaginaram que a casa dos artistas visuais encontrasse um porto seguro. 


\section{BARUERI - Gibiteka Municipal fica na Biblioteca Prof. Max Zedron}

Rua Rio Grande do Sul, 234 - Vila Boa Vista

Contato: (11) 4198-0229 / bibl.maxzendron@ barueri.sp.gov.br

Funcionamento: Segunda a Sexta das $9 \mathrm{~h}$ às $20 \mathrm{~h} /$ Sábados das $13 \mathrm{~h}$ às $17 \mathrm{~h}$

\section{BELÉM DO PARÁ - Centur - Gibiteca da Biblioteca Arthur Vianna}

Av. Gentil Bittencourt, $650-3^{\circ}$ Andar

Contato: (91) 3202-4337 / cbpav@ fcp.pa.gov.br

Funcionamento: $8 \mathrm{~h} 30$ às $18 \mathrm{~h}$ de segunda a sexta

\section{BELO HORIZONTE - Gibiteca Antônio Gobbo - Biblioteca Pública Infantil e} Juvenil de Belo Horizonte

Praça da Estação, s/nº - Centro - Centro de Referência da Juventude

Contato: (31) 3277-8658 / bpij.fmc@pbh.gov.br; educativo.bpijbh@pbh.gov.br

Funcionamento: $3^{\mathrm{a}}$ a $6^{\mathrm{a}}$ das $9 \mathrm{~h}$ ás $19 \mathrm{~h}$, sáb. das 9h ás $14 \mathrm{~h}$

\section{CURITIBA - Gibiteca de Curitiba}

Rua Presidente Carlos Cavalcanti, 533, Solar do Barão - Centro

Contato: (41) 3321-3250 / gibitecadecuritiba@fcc.curitiba.pr.gov.br

Funcionamento: $9 \mathrm{~h}$ às $12 \mathrm{~h}$ e $14 \mathrm{~h}$ às $18 \mathrm{~h}$ ( $3^{\mathrm{a}}$ feira a sábado)

FORTALEZA - Gibiteca de Fortaleza - anexo da Biblioteca Dolor Barreira Av. Universidade, 2572, Benfica 
Contato: (85) 3105-1299 / https://www.facebook.com/gibitecadefortaleza

Funcionamento: Segunda a sexta, das 8:00 às 17:00

\section{GOIÂNIA - Gibiteca Jorge Braga}

Centro Cultural Marietta Telles, Praça Cívica ${ }^{\circ} 2$ - setor central

Contato: (62) 3223-5715 / https://site.seduce.go.gov.br/centro-cultural-marieta-telles-machado/

Funcionamento: Segunda a sexta, das 8:00 às 17:00

\section{SANTOS - Gibiteca Municipal Marcel Rodrigues Paes}

Posto 5, Orla do Boqueirão

Contato: (13) 3288-1300

Funcionamento: Seg - Sex: 9h às 19h; Sab - Dom: 9h às 13 h.

\section{SANTO ANDRÉ - Gibiteca de Santo André}

Praça IV Centenário, 1 - Centro

Contato: (11) 4433-0760 / gibiteca.santoandre@gmail.com

8:00 às 18:00 - de segunda à sexta-feira e sábados das 8:00 às 12:00

\section{SÃO BERNARDO DO CAMPO - Gibiteca Municipal Eugênio Colonnese}

Rua Nicolau Filizola, 1.100 - Centro (Poupatempo)

Contato: (11) 4336-8214 / gibitecasbc@gmail.com

Horário de funcionamento: segunda a sexta 7h00 às 19h00 /Sáb. 7h00 às 13 h00

\section{SÃO PAULO}

Gibiteca Henfil - Centro Cultural São Paulo 
Rua Vergueiro 1000 - Paraíso

Contato: (11) 3397-4090 / gibiteca@ prefeitura.sp.gov.br

Funcionamento: Terça a sexta, das $10 \mathrm{~h}$ às 20h, sábados, domingos, feriados e pontos facultativos (exceto Carnaval e Páscoa), das 10h às 18h (A entrada é permitida até 30 minutos antes do fechamento)

\section{Gibiteca da Biblioteca Infanto-Juvenil Viriato Correa}

Rua Sena Madureira, 298 - Vila Mariana

Contato: (11) 5573-4017 e 11 5574-0389 / bcsp.vcorrea@prefeitura.sp.gov.br

Funcionamento: $2^{\mathrm{a}}$ a $6^{\mathrm{a}}$ feira das $10 \mathrm{~h}$ às $19 \mathrm{~h}$, sábado das $11 \mathrm{~h}$ às $18 \mathrm{~h}$ e domingo das $11 \mathrm{~h}$ às $15 \mathrm{~h}$

\section{Biblioteca São Paulo - Carandirú}

Av. Cruzeiro do Sul, 2.630, Parque da Juventude Santana (ao lado da Estação Carandiru do Metrô).

Contato: (11) 2089-0800 / bcsp@ prefeitura.sp.gov.br

Funcionamento: De terça a domingo e feriados, das $9 \mathrm{~h} 30$ às $18 \mathrm{~h} 30$ horas.

\section{Biblioteca Infantil Monteiro Lobato}

Rua General Jardim, 485 - Vila Buarque

Contato: (11) 3256-4438 e (11) 3256-4122 / bcsp.mlobato@ prefeitura.sp.gov.br

Funcionamento: $2^{\mathrm{a}}$ a $6^{\mathrm{a}}$ feiras das $8 \mathrm{~h}$ às $18 \mathrm{~h}$, sábados das $10 \mathrm{~h}$ às $17 \mathrm{~h}$ e aos domingos das 10h às 14h, somente Sala Infantil e Exposição "Eu, Lobato"

\section{Biblioteca do Sesi}

R. Carlos Weber, 835, Vila Leopoldina 
Contato: (11) 3834-5523 / faleconosco@ sesisenaisp.org.br

Funcionamento: seg.: 9 h às $18 \mathrm{~h}$. Ter. a sex.: 7h às $18 \mathrm{~h}$. Sáb.: $10 \mathrm{~h}$ às $16 \mathrm{~h}$.

\section{Biblioteca Mário de Andrade}

R. da Consolação, 94, Consolação

Contato: (11) 3775-0002 / bma@ prefeitura.sp.gov.br

Seg. a sex.: 8 h às $22 h$. Sáb. e dom.: 8 h às $20 h$

\section{SERTÃOZINHO: Biblioteca Canaoeste}

Rua Frederico Ozanan, 842 - Sertãozinho

Contato: (16) 3524-2453

Funcionamento: segunda a sexta, das $8 \mathrm{~h}$ às $12 \mathrm{~h}$ e das $13 \mathrm{~h} 30$ às $17 \mathrm{~h} 30$ 
